Pontifícia Universidade C Católica

Flávio Renato Morgado Ferreira da Silva

A conquista do espaço:

Obra e obstinação de Amilcar de Castro

Dissertação de Mestrado

Dissertação apresentada como requisito parcial para obtenção do grau de Mestre pelo Programa de Pós-Graduação em História Social da Cultura do Departamento de História da PUC-Rio.

Orientador: Prof. Ronaldo Brito Fernandes 


\title{
A conquista do espaço: obra e obstinação de Amilcar de Castro
}

\begin{abstract}
Dissertação apresentada como requisito parcial para obtenção do grau de Mestre pelo Programa de PósGraduação em História Social da Cultura do Departamento de História do Centro de Ciências Sociais da PUC-Rio. Aprovada pela Comissão Examinadora abaixo assinada.
\end{abstract}

Prof. Ronaldo Brito Fernandes

Orientador

Departamento de História - PUC-Rio

Prof. Sergio Bruno Guimarães Martins

Departamento de História - PUC-Rio

Prof $^{\mathrm{a}}$ Vera Beatriz Cordeiro Siqueira

Instituto de Artes - UERJ

Prof. Augusto César Pinheiro da Silva

Vice-Decano de Pós-Graduação do Centro de Ciências Sociais - PUC-Rio 
Todos os direitos reservados. É proibida a reprodução total ou parcial do trabalho sem a autorização da universidade, do autor e do orientador.

\section{Flávio Renato Morgado Ferreira da Silva}

Graduou-se em História pela Universidade Federal do Rio de Janeiro (UFRJ) em 2014 com a monografia "Seleção e silêncio: documentos coligidos para a História pátria do Brasil por José Maria Vaz Pinto Coelho em 1891”. Publicou dois livros de poesia: "Um caderno de capa verde" (7Letras/2012) e "Uma nesga de sol a mais" (7Letras/2016). Atua como professor de Ensino Médio no Rio de Janeiro.

Ficha catalográfica

Silva, Flávio Renato Morgado Ferreira da

A conquista do espaço : obra e obstinação de Amilcar de Castro / Flávio Renato Morgado Ferreira da Silva ; orientador: Ronaldo Brito Fernandes. 2018.

92 f. : il. color. ; $30 \mathrm{~cm}$

Dissertação (mestrado)-Pontifícia Universidade Católica do Rio de Janeiro, Departamento de História, 2018.

Inclui bibliografia

1. História - Teses. 2. História Social da Cultura - Teses. 3. Amilcar de Castro. 4. Neoconcretismo. 5. Escultura. 6. História da arte. 7. Arte. I. Fernandes, Ronaldo Brito. II. Pontifícia Universidade Católica do Rio de Janeiro. Departamento de História. III. Título. 
À Maria Santa'Anna da Cruz Morgado,

porque não haveria outra. 


\section{Agradecimentos}

Em grau hierárquico, ao Ronaldo, pela paciência e aprendizado.

À Edna Maria Timbó, secretária e medula do departamento de História; ilha de afabilidade em meio a sisudez acadêmica.

Ao Italo, irmão-corsário, que a essa áspera proa ainda foi comigo.

Aos meus irmãos, para que icem as próprias velas.

Aos meus pais, pela vida.

A minha avó, Santana, pelos pássaros e o voo.

À Brás de Pina e sua contra-educação.

À Pollyana Quintella, pelo auxílio, interlocução e gás.

Aos meus colegas, pelo abraço em meio a esse umbral que muitas vezes se torna a carreira universitária.

Ao mestre Manoel Salgado, afetiva e justamente, pela memória.

Ao Ferreira Gullar, poeta e vestígio vivo nesse texto.

E em grau hierárquico que quase sempre compete aos poemas - de guardar o sumo em seus últimos versos - à Raissa. 


\section{Resumo}

Silva, Flávio Renato Morgado Ferreira da; Fernandes, Ronaldo Brito. A conquista do espaço: obra e obstinação de Amilcar de Castro. Rio de Janeiro, 2018. 92p. Dissertação de Mestrado - Departamento de História, Pontifícia Universidade Católica do Rio de Janeiro.

Esta dissertação pretende analisar a obra do artista Amilcar de Castro (19202002) desde os seus primeiros desenhos, ainda sob a influência de seu antigo professor, o pintor Guignard, passando por sua adesão à vanguarda neoconcretista e à luz de conceitos como tridimensionalidade, raciocínio planar e topologia, suas esculturas, sobretudo, de corte e dobra e seus sólidos geométrico afirmam com mestria a inserção de um pensamento construtivo no Brasil. Se por um lado seu trabalho se aproxima e o torna signatário do movimento, por outro, Amilcar alcança sua singularidade em uma obra de profunda dimensão existencial e que mesmo em outros suportes (como os desenhos sobre tela e os poemas) mantém seu rigor e seu impulso estrutural e existencial. Partindo de uma linguagem construtiva que compreende a forma enquanto seu aparecimento e a negação de um espaço virtualmente dado, Amilcar constrói uma coerente aventura fundamentada a uma obstinação que o acompanhou por toda vida: a conquista do espaço.

\section{Palavras-chave}

Amilcar de Castro; neoconcretismo; escultura 


\section{Abstract}

Silva, Flávio Renato Morgado Ferreira da; Fernandes, Ronaldo Brito (Advisor). The conquer of space: work and obstination of Amilcar de Castro. Rio de Janeiro, 2018. 92p. Dissertação de Mestrado - Departamento de História, Pontifícia Universidade Católica do Rio de Janeiro.

This research aims to examine the work of Amilcar de Castro since his first drawings, under the influence of his old teacher, the painter Guignard, in which we can already see the incision Over matter, the gesture That would define his sculptures, and the choice of drawings as primal force of his structural impulse. Passing through his relation with neoconcretist avantguard, and the ideias of 3D, planar thought and topology, his sculptures are an effort of building constructivist art and thinking in Brazil. Amilcar reaches his singularity through a work of deep existencial character, That even by other means (like drawings and poems) keep it's toughness and existencial impulse. Working with the ideia of constructive language, that sees "form" as language's appareance and denial of a virtually given space, Amilcar builds a work on basis of something that concerns him over all his life: the conquer of space.

\section{Keywords}

Amilcar de Castro; neoconcretism; sculpture 


\section{Sumário}

Introdução

Capítulo I: Aproximação entre Amilcar e Guignard

Capítulo II: Amilcar e o Neoconcretismo

2.1. A arte concreta no Brasil 26

$\begin{array}{ll}2.2 \text { O Neoconcretismo } & 29\end{array}$

Capítulo III: Amilcar singular $\quad 47$

3.1. Outros suportes: desenho sobre tela e poema 65

Considerações finais $\quad 82$

$\begin{array}{ll}\text { Referências bibliográficas } & 87\end{array}$

$\begin{array}{ll}\text { Anexo } & 90\end{array}$

$\begin{array}{ll}\text { Anexo I. Obras citadas } & 90\end{array}$ 
passarinho que se debruçao voo já está pronto.

João Guimarães Rosa 


\section{Introdução}

Com uma obra que atravessou mais de meio século em uma aventura de rara e profunda coerência, Amilcar de Castro surge como um dos mais relevantes mestres ao se falar em arte tridimensional no país. Desde sua primeira escultura na linguagem que adotou definitivamente para expressar-se, sua presença como artista tornou-se inexcedível ao contexto do qual emergiu e consolidou-se: o Projeto Construtivo Brasileiro ${ }^{l}$.

Desde seus primeiros desenhos, ainda aluno do consagrado pintor, mestre e seu amigo, Alberto da Veiga Guignard, é possível reconhecer seu impulso estrutural, seu gesto incisivo e fundador. $\mathrm{O}$ valor da geometrização do mundo; a maneira construtiva que Amilcar já começa a esboçar em suas primeiras telas sobre Minas Gerais (sua terra natal) ao se deparar com a dissolução e a descoberta do espaço da tela nos trabalhos de seu antigo mestre. Uma coerência que se já se mostrava original na formação de um sujeito estético que encontraria no livre didatismo e brilhante influência de Guignard o espaço adequado para se desenvolver.

Os passos seguintes, o impacto da unidade tripartida de Max Bill em seu trabalho, a adesão à vanguarda construtiva e posteriormente a criação do movimento neoconcreto. Os passos do artista sincronizados ao seu tempo, à vanguarda a qual seu trabalho pode se consolidar e traduzir os anseios de uma arte construtiva que fosse sensível e ativa - uma ruptura ao racionalismo ortodoxo dos concretos de São Paulo. E também os decididos passos de Amilcar que, incapazes de se dobrarem aos imperativos de vanguarda, constroem uma trajetória única, singular, que em muitos aspectos se distancia de seus companheiros neoconcretistas e o repõe a esse caminho solo e consistente, desde sempre preconizado.

Seu raciocínio estrutural afirma sua potência lírica. Amilcar é coerente em suas escolhas ao obedecer a princípios muito bem estabelecidos em seu léxico: o ferro, a escala de confronto, o corte, a dobra, o plano (origem e impossibilidade), os deslocamentos. Amilcar adere ao material industrial, desde que ele corresponda

\footnotetext{
${ }^{1}$ Entende-se por Projeto Construtivo Brasileiro o conjunto de proposições acerca da entrada e do desenvolvimento da ideia construtiva sobre a produção de arte. Ronaldo Brito, em "Neoconcretismo: vértice e ruptura do projeto construtivo brasileiro", parte da premissa de que o raciocínio pós-cubista, fundamentado no desenvolvimento e apuro da forma, na reposição das artes plásticas em sua capacidade inventiva e não mimética, figurativa, encontraria nas vanguardas brasileiras da década de 1950 seu desdobramento e auge. Ver em BRITO, Ronaldo. Neoconcretismo: vértice e ruptura do projeto construtivo brasileiro. São Paulo: Cosac Naify, 1999
} 
às suas premissas existenciais. Com o ferro é possível inserir o tempo enquanto dimensão da obra. Feitas em diferentes tamanhos, principalmente devido aos ditames do escasso mercado brasileiro em relação ao aço cor-ten, material de sua preferência, suas esculturas mantém uma relação intrínseca e poética entre espessura e escala. Predomina a escala coloquial - o convite ao confronto. O corte como desenho e fissura. A dobra como a conquista da tridimensionalidade e reflexividade do próprio material. Seus deslocamentos como outra forma de experimentar o espaço e (por que não?) o mundo.

O objetivo deste trabalho é analisar a trajetória de Amilcar de Castro, partindo dos primeiros indícios de seu pensamento construtivo, passando pelos diálogos e pelas particularidades de seu trabalho dentro do movimento neoconcretista (sobretudo suas esculturas), sem deixar de ressaltar a originalidade e a coerência de um trabalho que lançando-se também sobre outros suportes (desenhos em tela, poemas) ampliou ainda mais esse seu intransferível repertório. Uma obra de profunda marca existencial que reconhece em seu ímpeto, para muito além de um projeto, uma obstinação: a conquista do espaço como afirmação de seu estar no mundo. 


\title{
Capítulo I - Aproximação entre Amílcar e Guignard
}

O ano é 1944. O então prefeito de Belo Horizonte, Juscelino Kubitschek, convida o artista Alberto da Veiga Guignard para dar "ares mais modernos" à Escola de Belas Artes da cidade. A capital mineira deveria acompanhar as novas tendências e a livre didática do pintor seria a alternativa ao academicismo da época. Ao chegar, Guignard contava com seus quase cinquenta anos, já era um reconhecido pintor modernista, e assumia o novo desafio com um único objetivo: a modernização pretendida só poderia partir de um intenso estímulo à liberdade e aos questionamentos individuais de cada aluno. Posteriormente, o Curso de Desenho e Pintura de Guignard, por iniciativa da prefeitura, mas já com a influência do pintor, é incorporado ao Curso de Arquitetura, que já funcionava como curso livre. Clara intenção de não deixar a Escola subordinada à academia e que ressalta a transformação gerada por sua presença na cidade.

\begin{abstract}
traduzida na sua extraordinária autoridade em assuntos artísticos de preparo notório em todo país, preenchia, por si só, um vazio infra-estrutural no então chamado campo das belas-artes. Não havia necessidade de uma estrutura burocrática para o funcionamento da escola. Os caminhos pedagógicos eram traçados como que de improviso, de acordo com a orientação do mestre. Os resultados deste liberalismo didático foram rápidos e de alta positividade, mas circunscrito em momento histórico bem diferente do atual. Àquela época, na cidade de Belo Horizonte, as artes plásticas não se incluíam entre as atividades que possibilitavam a profissionalização. Figuravam como disciplina que enriquecia o potencial cultural dos indivíduos, entretanto não lhe permitia a dedicação plena. A função deste liberalismo didático a de proporcionar à sociedade um salto histórico, possibilitando-lhe uma grande evolução nas concepções estéticas. ${ }^{2}$
\end{abstract}

No mesmo ano, ainda no terceiro ano da faculdade de Direito, matricula-se no curso de desenho de Guignard o jovem Amilcar de Castro.

Em jornadas de exercícios que muitas vezes se estendiam aos bares da cidade, Amilcar teve como base do ensino de Guignard o desenho, a rigorosa observação do mundo objetivo, para que, dominado, possa ser impregnado de

\footnotetext{
${ }^{2}$ MOURA, Antonio de Paiva. "Memória histórica da Escola Guignard". Belo Horizonte: Sindicato dos Escritores, 1993. $80 \mathrm{p}$.
} 
fantasia na medida certa. A linha direta e sensível. A força que organiza o surgimento da imagem. ${ }^{3}$

O "Mestre", como era chamado por Amilcar, era conhecido pelo liberalismo didático e a preocupação com as qualidades artísticas de seus alunos. Talvez por isso não ser tão incomum que mesmo que algumas aproximações sejam possíveis entre esses dois artistas, seus caminhos, suas pesquisas, tomam rumos diferentes exatamente porque a preocupação de Guignard não tenha sido de formar um séquito de pintores com seu mesmo padrão e indagações. Sua atenção estava voltada às particularidades. A originalidade e consistência do trabalho de Amilcar de Castro comprovam a eficácia de sua escuta.

O Mestre na verdade não ensinava como desenhar ou pintar. Era mais um amigo. E tinha a percepção do que cada um era capaz. Impunha uma disciplina rigorosa para os alunos, mas com sabedoria conduzia-os no sentido de alcançar o melhor resultado dentro do trabalho. Estabelecia-se assim uma relação de amizade e confiança, que foram muito importantes para Amilcar acreditar que podia redirecionar sua vida e seguir rumo as artes. E foi o que fez. ${ }^{4}$

Com Guignard, foi introduzido na técnica do lápis duro, com o qual sulcava as folhas de papel, primeiro índice dos futuros cortes que faria nas chapas que tanto marcariam seu trabalho, reconhecíveis pelas monumentais esculturas em aço cortadas e/ou dobradas. E ainda que seus primeiros desenhos, como "Vista de Ouro Preto" (1949), mantenham a aproximação temática com o professor, o que o caracterizaria posteriormente, já se deixava evidente nas primeiras tentativas ainda sobre papel: o gesto decidido, o desdobramento geométrico, o curso livre de sua poética.

"Dessa maneira não havia como enganar o professor. Não havia como corrigir o traço, o grafite feria o papel, ficava a ranhadura, o sulco. Foi com esse sentido de precisão que aprendi desenho com Guignard. O sentido de fazer e estar valendo. Riscou está riscado, não há como corrigir. É o jeito alemão, aprender na base do vai ou racha."5

Em seus primeiros esboços, é possível acompanhar a evolução desse processo. Há nos primeiros a força do gesto fundador, certa geometrização,

\footnotetext{
${ }^{3}$ BRITO, Ronaldo. Amilcar de Castro; fotos Rômulo Fialdini. São Paulo: Takano Editora, 2001.

${ }^{4}$ http://www.institutoamilcardecastro.com.br/assets/iacsp2.pdf.

${ }^{5}$ BRITO, Ronaldo. Amilcar de Castro; fotos Rômulo Fialdini. São Paulo: Takano Editora, 2001.
} 
principalmente no que se refere à articulação geométrica entre essas figuras. E a esse aspecto Amilcar também estava atento. A força inaugural de seu gesto seria a principal marca ao longo de seus trabalhos, como em alguns trabalhos do professor, desdobrava-se, sobretudo, numa indagação sobre o espaço.

$\mathrm{Na}$ disponibilidade absoluta de um mundo sem entraves, o desenho, antes da escultura, evidencia sua inspiração geométrica: de saída ele precisa do plano em branco do papel. Quando ainda aluno de Guignard, seus desenhos já traria o impulso físico do ato de estruturar, sua vontade de ordem ao traçar os telhados de Ouro Preto, a preferência pelas formas regulares, o gesto decidido que, como seu professor, opera uma fenomenologia do aparecimento ${ }^{6}$.

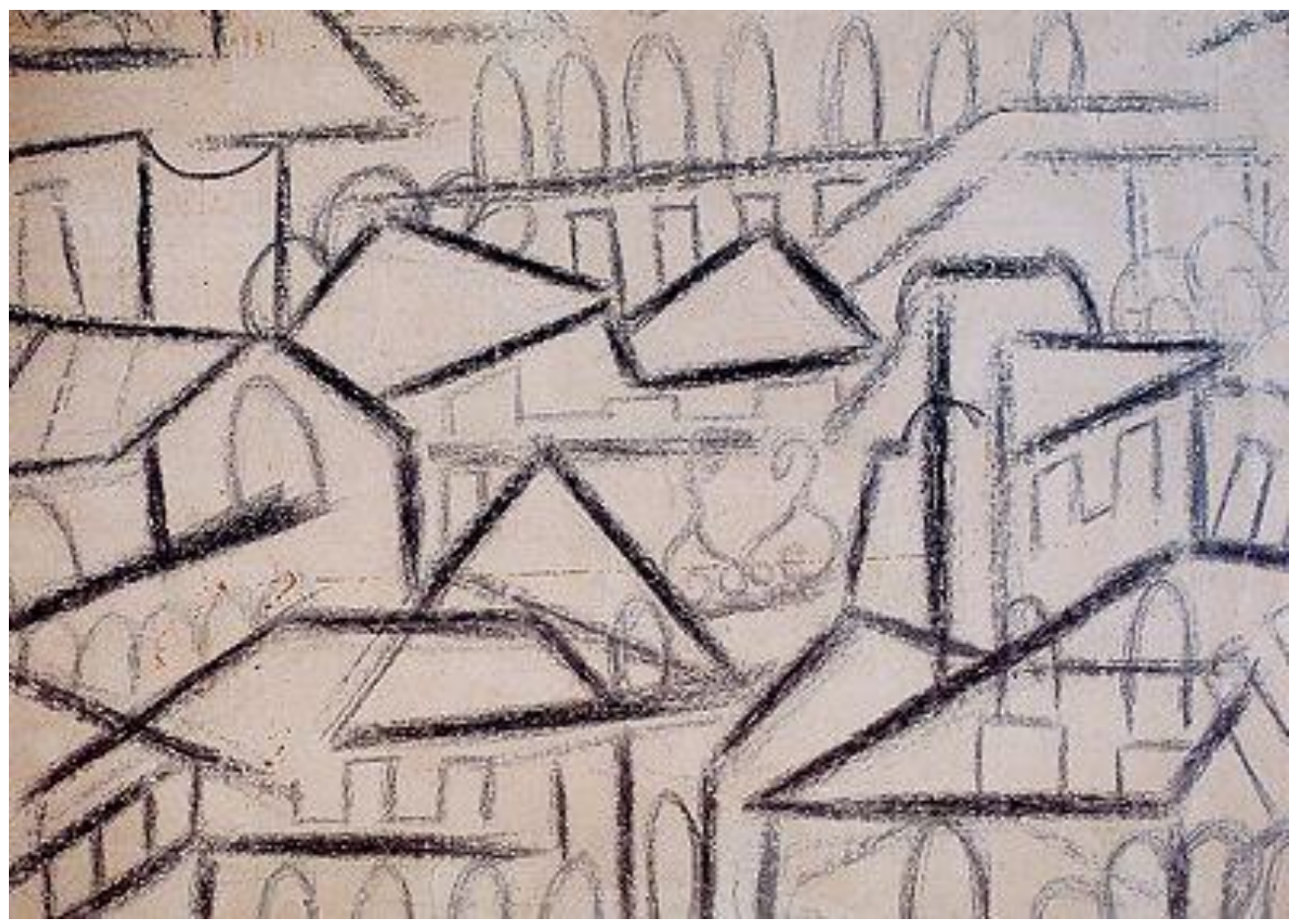

(Vista de Ouro Preto, 1949. Amilcar de Castro) [1]

\footnotetext{
${ }^{6}$ Entende-se por fenomenologia a "descrição daquilo que aparece ou ciência que tem como objetivo ou projeto essa descrição" (ABBAGNANO. 2000. P. 437). Nesse sentido, partimos do projeto analítico do fenomenólogo alemão Edmund Husserl, que propõe como método de investigação a apreensão do fenômeno enquanto tal. Na obra de Amilcar, esse aparecimento repõe o conceito de fenômeno na medida em que seus trabalhos partem de uma força estruturante baseada em sua própria produção de negatividade (voltaremos a esse ponto mais adiante), não representacional e, portanto, fundamentada na fruição de seu próprio desdobramento no espaço. Em suas múltiplas formas de apreensão e percepção. Ver sobre fenomenologia em HUSSERL, Edmund. A Ideia da Fenomenologia. Trad. Artur Morão. Lisboa, Port.: Edições 70, 2014.
} 
Vista de Ouro Preto, trabalho de 1949, traduz a potência estrutural do jovem Amilcar de Castro. À precisão de seu gesto fundador, o aparece a paisagem enquanto progressiva combinação geométrica de seus telhados. Fruto de um interesse pelo trabalho de Guignard que vai além da temática e amplia seu repertório lírico, sua relação com o desenho, a problematização na relação entre figura e fundo, a conquista do espaço, que em trabalhos como esse, é solucionado a partir de seu nexo geométrico. De um artista que antes de seguir qualquer premissa formalista, já punha a geometria à conquista do espaço.

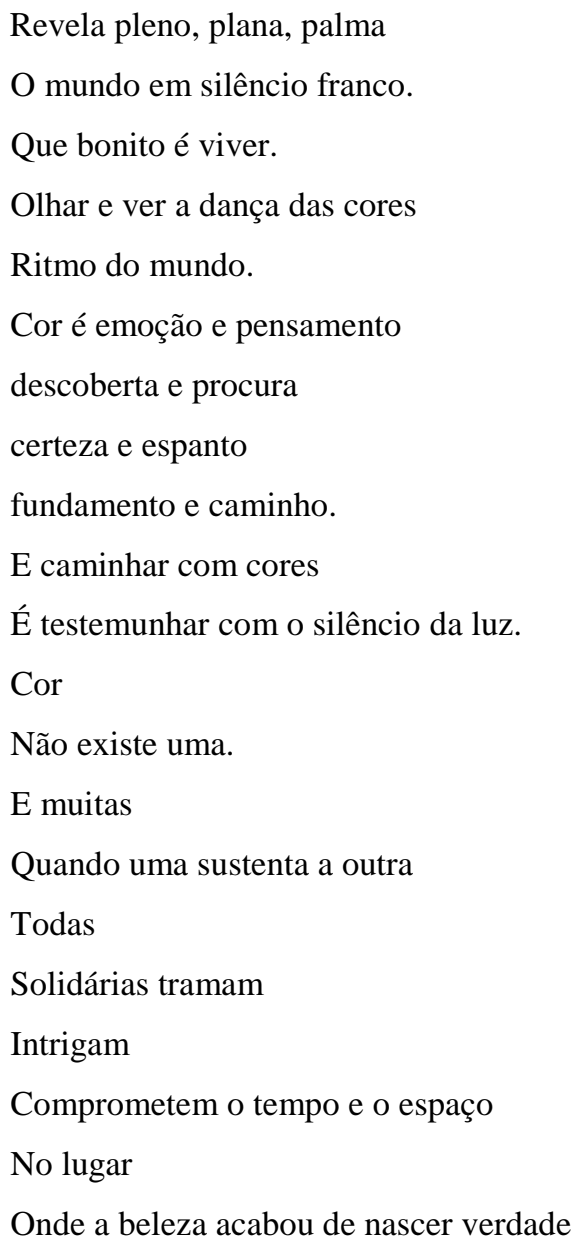

(Guignard - Pintor, Amílcar de Castro, em “Catálogo” Museu Lasar Segall, 1992)

Um dos trabalhos mais reconhecidos de Guignard são suas pinturas sobre as festas juninas e as paisagens de Minas Gerais, terra natal de Amilcar de Castro e local onde os dois conviveram. Há uma aproximação fundamental entre esses trabalhos e os primeiros desenhos de Amilcar. Em uma dessas telas, Noite de São 
João, de 1943, Guignard parte da composição de relevos em suas pinceladas de óleo sobre madeira a medida que seus balões surgem em uma noite triste, de complexidade crescente, como um descentramento que nos obriga a abandonar a possibilidade de uma ordenação que reunificasse tudo de maneira pacífica. Amilcar compreendeu o desdobramento espacial desses objetos aéreos, e mais ainda, o valor existencial de seu motivo - suas noites são solitariamente existenciais.

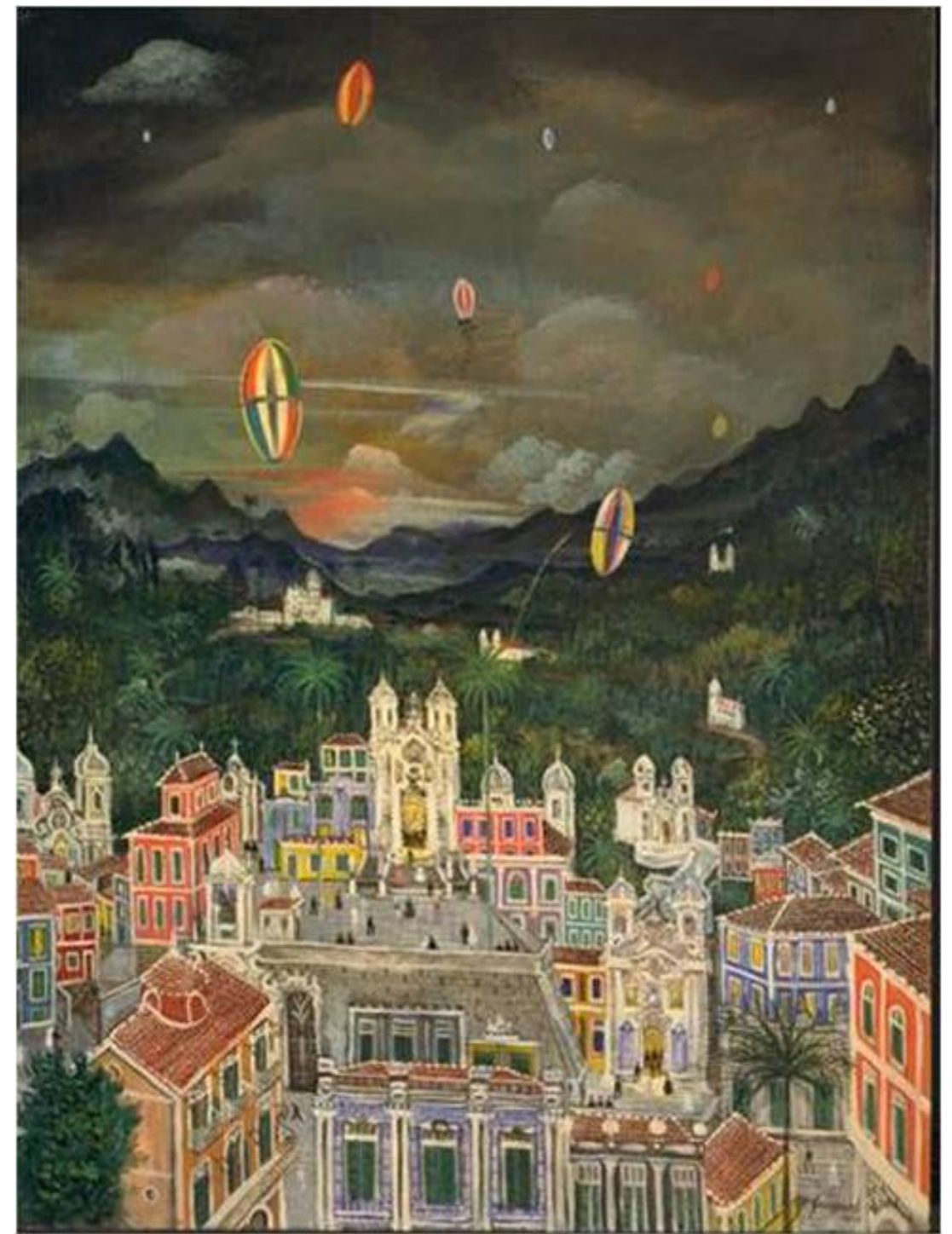

(Noite de São João, 1943. Alberto da Veiga Guignard) [2]

A inteligência metódica do geômetra nos telhados de 1949 não impede a fluidez do artista, capaz de improvisar a partir da forma. A paisagem que, construtivamente, aparece como se partisse de uma primeira forma geométrica e 
desdobrasse todos os outros telhados com a avidez de quem pouco a pouco conquista o espaço do papel. O protagonismo de seus telhados explica o desenvolvimento formal do trabalho, assim como a escolha do próprio material, pode ser um indicativo de sua potência poética. O lápis de cera e suas possibilidades de iluminação e opacidade, como material que retém a luz, como o aço cor-ten de suas futuras esculturas. A dificuldade em eliminar os rastros do erro, do exercício, e por isso, assumi-lo como gesto fundador e irrevogável. O acaso ao caminho da necessidade - o traço incisivo e o desenvolvimento geométrico até a conquista do espaço, objetivo final. A paisagem não dorme às nossas costas, ela aparece, fenomenologicamente, ao passo em que é vista. E ainda que partindo de um raciocínio estrutural, seus trabalhos jamais evoluem na atmosfera virtual da mentalização geométrica. Já que inexiste espaço ideal, há somente o espaço conquistado pelo artista. Amilcar, nesse sentido, diverge da ortodoxia concreta na medida em que opera em termos existenciais não só no dilema empírico que a passagem de seu desenho para a matéria revela, mas abriga-se, sobretudo, em conscientes escolhas ao longo do processo, de seus desenhos às esculturas, a começar por fugir do anonimato banal dos materiais concretistas (ou a falta de caráter do alumínio, como dizia) e lançar-se à aventura temporal do aço cor-ten oxidado. E, ao contrário do que poderíamos supor em relação aos seus desenhos como uma estrutura prévia de raciocínio, o artista ainda que lançasse mão de figuras geométricas regulares (o que já comparece no desenho de 1949), não abraça a geometria euclidiana, envolvendo-se no espaço, estão no mundo, como formas que se inauguram a todo momento, como acontecimentos.

Ensinou a desenhar a lápis 7, 8, 9H.

Esse método de desenho trouxe gosto pelo bem feito.

Sem sombras.

Pelo que é sensível, sem exageros sentimentais.

Pela comunicação direta, sem adjetivos ou preciosismos.

Foi o que nos deu o conhecimento da linha.

Ela mesma, o caminho, o ritmo.

O que separa e valoriza espaços.

O que é força e suavidade ao mesmo tempo.

Sem intermediários.

Música necessária.

Solo de tempo contido na precisão do espaço. 
E trama e tece teia de poesia, linha de luz sobre

Ouro Preto que amanhece agora.

Foi o que fez com absoluto talento e sabedoria. Grande Mestre. ${ }^{7}$

O poema de Amilcar dedicado a Guignard revela a admiração e o reconhecimento de exatos valores plásticos e poéticos gestados nos diálogos com seu mestre que marcariam sua obra até o fim.

Antes de partir para suas esculturas, é importante nos debruçarmos sobre seus desenhos, mesmo os já concebidos nas décadas de 80 e 90, mas que na impossibilidade do material (papel, gravura em metal ou pintura) de seu desdobramento geométrico à maneira que iria encontrar na oxidação e na opacidade de seu aço cor-ten, deixavam ainda assim patente o que no poema dedicado ao Mestre o poeta se refere a: 'Pelo que é sensível, sem exageros sentimentais./ Pela comunicação direta, sem adjetivos ou preciosismos./ Foi o que nos deu o conhecimento da linha./ Ela mesma, o caminho, o ritmo./O que separa e valoriza espaços. ${ }^{8} "$

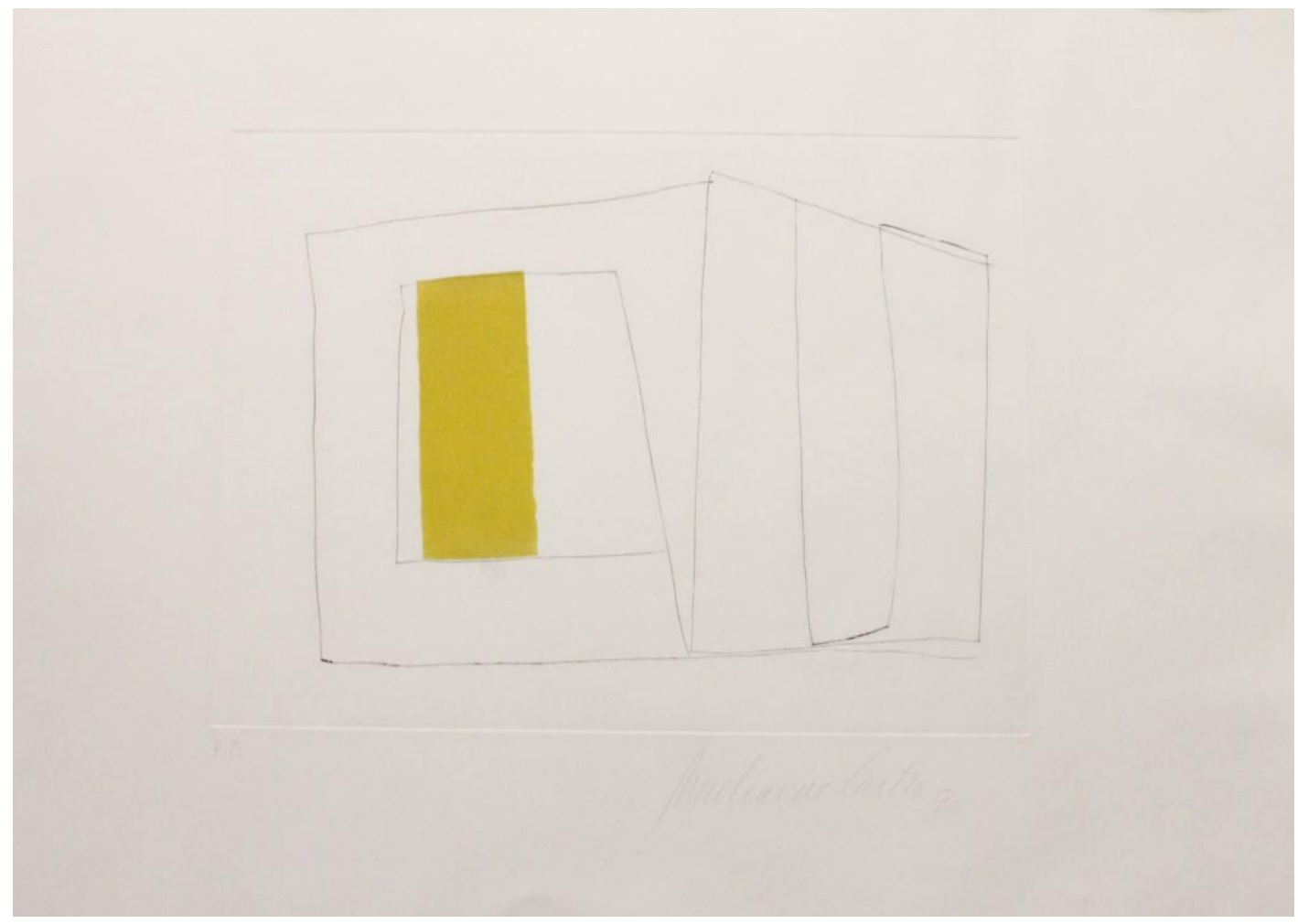

(Sem título, 1990 - Amilcar de Castro) [3]

\footnotetext{
${ }^{7}$ http://www.institutoamilcardecastro.com.br/assets/iacsp2.pdf

${ }^{8}$ Idem
} 


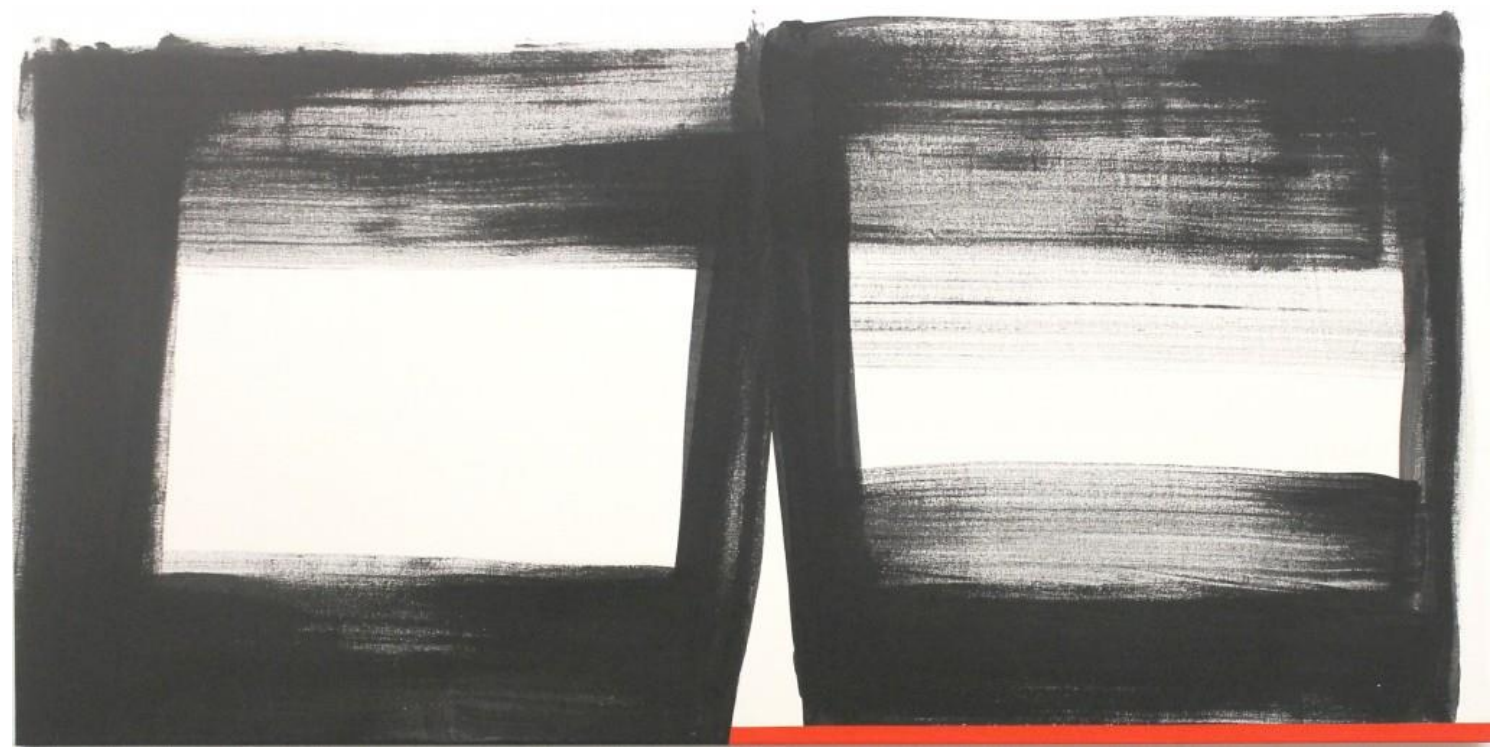

(Sem título, 1999 - Amilcar de Castro) [4]

A relação de Amilcar com o espaço é o motivo de seu desenho. Partindo de inúmeras possibilidades (a tela em branco), seu esforço não é o do preenchimento, sim do uso da linha como baliza de um vazio, agora configurado enquanto espaço visível. O desenho retoma seu gesto fundador, afirma o ato de especializar. Não há excesso, nem contorno, é a vitória do simples, da comunicação direta que tanto falava.

Especialmente no primeiro desenho (gravura sobre metal) a cor é um ponto decisivo. Ela não é projetiva, mas decisivamente composicional na relação com o espaço. Não há mimesis, e sim poiesis. Um ato de criação, de construção a partir da cor. Amilcar garante a "luminosidade" de seu branco espaço ao contraste do vivo amarelo cromo: retangular, geométrico, apenas o necessário, não o motivo, sem exageros sentimentais, não-representacional, limite e participante.

Já no segundo desenho (acrílica sobre tela) prevalece outra relação: o minimalismo retoma seu espaço construtivo no trato da cor e do gesto.

Se pensarmos que o preto teria a mesma função opaca da escolha posterior de seu material escultórico, é possível compreender não só a cor mais uma vez em seu protagonismo construtivo, mas como o próprio gesto do artista - de uma só vez, com uma escova, não um pincel, desdobrado, adâmico, sem correção ou 
retoque - é a possibilidade de iluminação a partir do próprio ato. Sendo uma escova e não um pincel, suas cerdas espaçadas acusam a matéria-fundo, também a reinsere enquanto espaço integrante da obra e dá ao restante do desenho a mesma impressão que algumas de suas esculturas teriam: (1) o uso da luz, (2) a opacidade do material versus a livre iluminação do espaço construído a partir de suas dobras.

Nada é gratuito. O espaço formado entre as figuras geométricas (feitas no mesmo gesto) ganha outra significação exatamente pela escolha do vermelho ao canto direito da tela. $\mathrm{O}$ que poderia ser mero vão entre as figuras, uma sobra, ou daria às figuras o protagonismo representacional do quadro, passa a ser visto como mais um desses vazios-significantes ou novos espaços conquistados a partir do desenho. Há, portanto, nesses dois exemplos uma amostra do que seria a pesquisa de Amilcar, uma investigação sobre as possibilidades de espaço, uma batalha com a fácil percepção, com o real que não apresenta novas visadas e significações. Fosse na escultura, no desenho, sua voracidade, sua consistência, sua determinação e seu trato com o espaço partia da mesma questão.

Guignard, com sua livre didática, soube estar atento a essa inquietação. Vimos isso em seus primeiros desenhos (em Ouro Preto) e compreendemos isso a partir de uma aproximação temática e técnica, até certo ponto, entre professor e aluno. Está lá. Nas "Noites de São João" de Guignard é possível ver como partindo de um outro trato com a pintura, o Mestre dissolve figura e fundo e amplia nossa percepção sobre o espaço pictórico na tela. Lírico, um espaço que nos diz solidão.

Guignard de certo modo leva ao limite aquele trauma da presença que marca a arte brasileira. Sua pintura - e mais acentuadamente suas paisagens lavadas e difusas - tem uma qualidade indiscutível. Toda ela porém se volta para a criação de uma superfície turva, onde nada alcança definição precisa. Cores e planos se misturam e se combinam, na formação de uma extensão fugidia, que recusa o surgimento de uma visualidade plena, que se entregue por inteiro ao observador. $O$ resultado são imagens relutantes e esmaecidas: o que se mostra parece ocultar uma realidade mais intensa, da qual temos apenas uma vaga percepção. ${ }^{9}$

\footnotetext{
${ }^{9}$ NAVES, Rodrigo. A forma difícil: ensaios sobre arte brasileira. Editora Atica, São Paulo. 1996. P. 248
} 


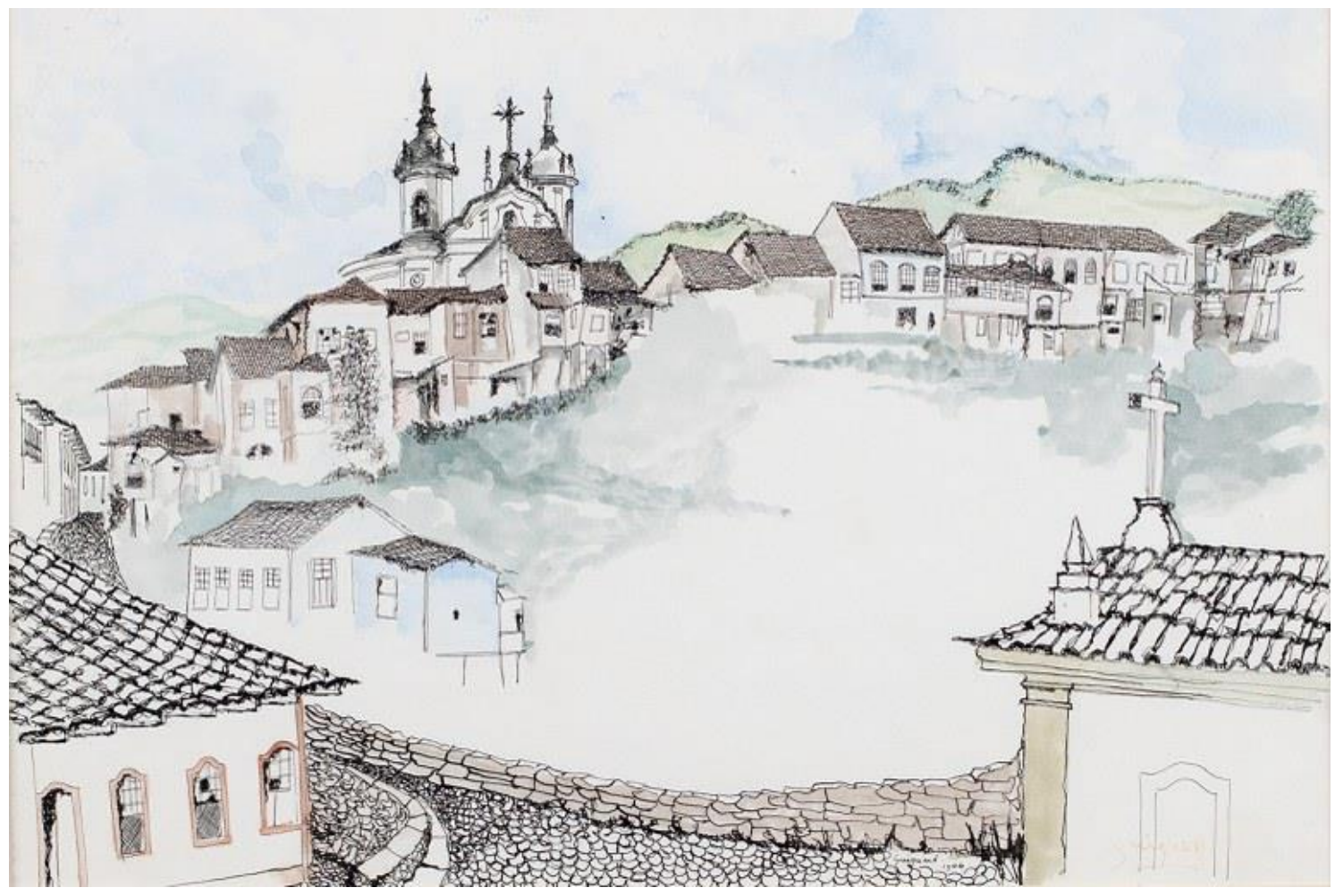

(Ouro Preto, 1946 - Alberto da Veiga Guignard) [5]

Equivocadamente, talvez por uma necessidade contextual do modernismo de buscar em seus artistas sobretudo os índices de brasilidade, dando pouca atenção ao desenvolvimento técnico e individual de cada artista, Guignard ficou conhecido por um trabalho orográfico ${ }^{10}$, quando partindo da mesma premissa poderíamos encontrar um exímio desenhista. A linha demarcatória dos espaços que sua tela constrói.

Em "Ouro Preto" de 1946, é flagrante o trato da linha enquanto recurso de espacialização. A construção de seus telhados, interligados, desdobráveis. A lápis duro a certeza dos telhados sobre casas diluídas na névoa de seu vazio central quase motivo de tão evidente. É lícito, inclusive, perceber uma aproximação na maneira em que seus telhados se desdobram à tela em relação ao desenho de seu pupilo Amilcar sobre a mesma Ouro Preto três anos mais tarde. A fronteira entre sombreamento e diluição no trato e na escolha dos tons de suas montanhas. E, com especial ênfase, o espaço que se constrói entre as casas, assegurando a perspectiva, e relembrando o uso da cor e da linha em Amilcar na intenção de deixar emergir

\footnotetext{
${ }^{10}$ Orografia: descrição das montanhas (fronteiras, altura etc.) por meio de instrumento técnico adequado.
} 
esse novo espaço em branco, agora integrante da pintura. Mais uma vez um vaziosignificante, o ápice da dissolução entre figura e fundo, quando o (supostamente) não pintado é tão significativo quanto o que se pretendeu em figura. Mais uma vez, Guignard não está descrevendo montanhas, e sim um vazio existencial e perceptível.

Muito provável que muitos diálogos sobre essa maneira de desenhar, de compreender o espaço e até suas inquietações existenciais tenha acontecido com uma boa frequência entre os dois, de toda forma, é fácil ver essa aproximação quase teórica. Se ao Mestre, cabia redefinir os caminhos dessa nova arte que a capital mineira tanto aspirava, sem dúvida a atenta missão de partir das indagações de seus próprios alunos, quando até então uma escola de arte era basicamente a transmissão dos valores estéticos da época, para ajuda-los a construir seus próprios trabalhos foi fundamental para o desenvolvimento de uma formação que privilegia o original e o inquieto. Como Amilcar, que restou levar seus questionamentos, sua poética precocemente percebidos, aos desdobramentos e circunstâncias de sua própria época. Sem esquecer o que de mais relevante a generosa escuta de seu Mestre construiu: a possibilidade do livre pensamento, da pesquisa insistente, da autoconsciência do artista Amilcar de Castro. 


\section{Capítulo II - Amilcar e o Neoconcretismo}

Quando, no fim da década de 1950 o "Manifesto Neoconcreto" foi escrito pelos artistas dissidentes do concretismo, para além de um movimento de vanguarda, no que concerne seu valor de ruptura e construção de novos imperativos, o neoconcretismo surge como um passo adiante na penetração do pensamento construtivista na arte brasileira.

Ainda com raras publicações sobre o tema, o embate entre o grupo de São Paulo (ortodoxia concreta, encabeçada por artistas como Waldemar Cordeiro e o poeta Haroldo de Campos) e o grupo do Rio de Janeiro (neoconcretos, signatários do manifesto de 1959) acaba por adotar o protagonismo nas discussões sobre o movimento. Com o distanciamento de mais de cinquenta anos da redação do Manifesto Neoconcreto, é necessário lançar sobre o período um olhar que relativiza as supostas divergências entre o neoconcretismo dos artistas cariocas e o construtivismo dos artistas e desenhistas industriais de São Paulo. Trabalhos, por exemplo, como Neoconcretismo: vértice e ruptura do projeto construtivo brasileiro (1985), do crítico de arte Ronaldo Brito, o primeiro a se debruçar teoricamente sobre o tema, analisa o movimento neoconcreto a partir de suas especificidades, não só enquanto resposta à vanguarda anterior, mas afirmação do próprio pensamento construtivo na arte brasileira ${ }^{11}$.

Após o período como aluno de Guignard, Amilcar muda-se para o Rio de Janeiro em 1953. Inicia sua carreira de diagramador em jornais da cidade e conhece os artistas cariocas que àquela altura já davam os primeiros passos rumo ao que seria o movimento neoconcreto. No Rio, Amilcar é aluno de escultura (ainda figurativa) de Franz Weissmann. Mas seria um outro modelo de escultura que o marcaria profundamente: o de Max Bill.

\footnotetext{
${ }^{11}$ BRITO, Ronaldo. Neoconcretismo: vértice e ruptura do projeto construtivo brasileiro. São Paulo: Cosac Naify, 1999. Página 34.
} 


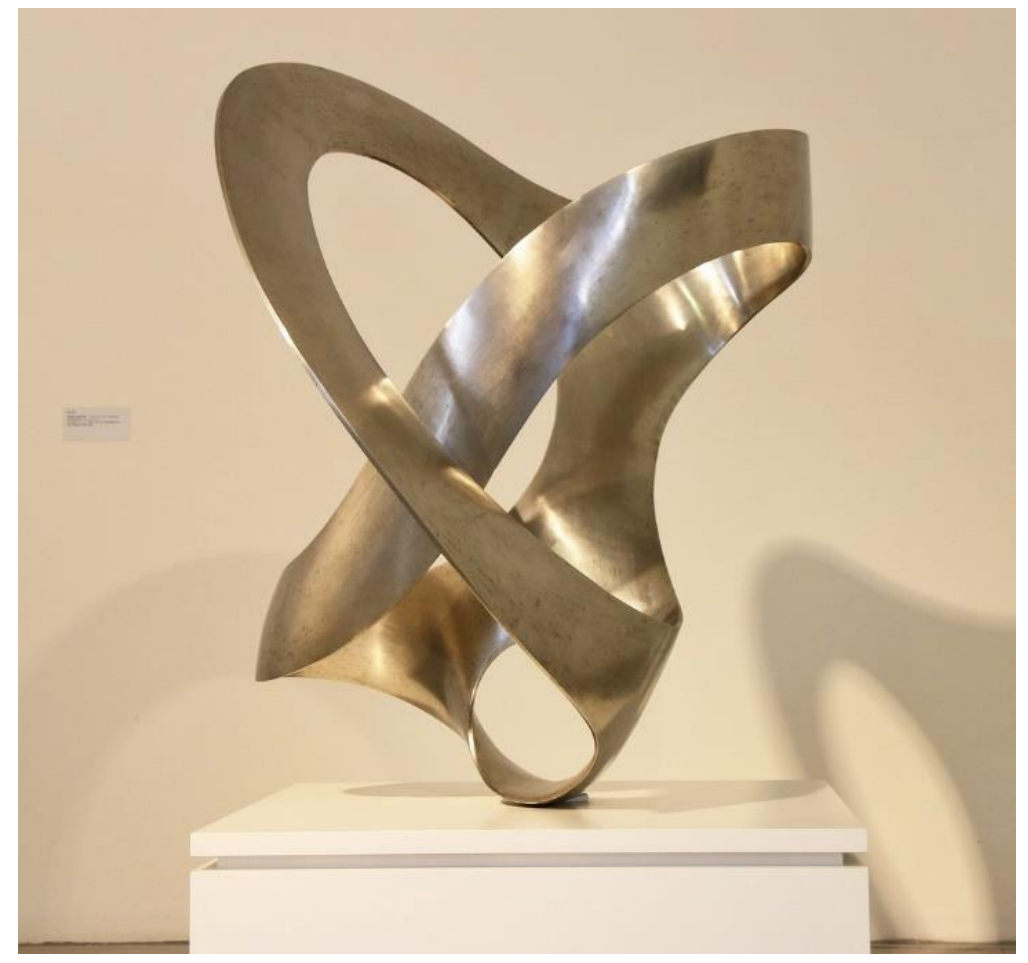

(Unidade Tripartida, 1949. Max Bill) [6]

Em 1951, o suíço Max Bill (1908-1994) recebe o prêmio da I Bienal Internacional de São Paulo. Momento simbólico, sobretudo à conjuntura artística do Brasil. O país buscava se afastar de sua vocação agrária e inserir-se no capitalismo moderno com seus investimentos voltados à industrialização e ao meio urbano. No pós-guerra, as sociedades passavam por uma fase de transição. Os países se voltaram para a busca de suas próprias soluções e formularam utopias. Não é à toa que o concretismo é contemporâneo do projeto desenvolvimentista de Juscelino Kubitscheck. Não se trata mais do convencimento à industrialização, mas dos reflexos de seu avanço e das novas possibilidades de aproximação entre arte e vida, entre o meio social e o artístico. Uma arte que não se restringia ao campo estético, que queria buscar suas aplicações na sociedade, no material industrial e nos postulados racionalistas de uma arte construtiva que já começava a conquistar seus primeiros entusiastas.

A arte concreta de Bill pretendia a consolidação da autonomia no processo de produção em arte em relação ao mundo natural, acentuava seu caráter sistemático, 
construtivo $^{12}$. Uma arte até então distante dos padrões da dita arte moderna brasileira, fugia completamente à antiga concepção representacional; gestada em uma sociedade industrial e urbana, a Unidade Tripartida (1949), a obra premiada, afasta-se de qualquer conotação simbólica ou lírica. O escultor defende a incorporação de processos matemáticos à composição. Partindo de uma estrutura planar, Bill conquista o espaço. Sua relação é plenamente topológica: a escultura se auto envolve, constitui-se dos desdobramentos de sua própria matéria (o aço) em relação ao espaço, não dado, mas construído, explorado ao exercício da forma. A unidade que coloca em xeque a noção de volume escultórico, explorando o conceito matemático da famosa fita de Moebius, a qual propõe um envolvimento geométrico da forma no espaço.

Ainda na década de 50, Max Bill fundaria a famosa Escola Superior da Forma, em Ulm, na Alemanha. Adaptada às circunstâncias históricas dos anos 50, à reconstrução da sociedade alemã no pós-guerra, a Escola de Ulm, em muitos sentidos um prosseguimento de Bauhaus, a cristalização de um racionalismo formalista. Atenta à demanda industrial, não à toa, aproxima-se do design, de seu caráter informacional:

\begin{abstract}
Não há vestígios de negatividade na prática da Escola de Ulm - representa um esforço para informar com "valores estéticos" e, implicitamente, como valores oriundos de uma ideologia funcionalista a produção de formas na sociedade. O seu desejo é racionalizar essa produção de formas, submetê-la a um controle técnico de sua estética e de sua operacionalidade ${ }^{13}$.
\end{abstract}

Um desenvolvimento cultural autônomo, não ideológico, de uma sociedade vista como um todo, e não em seus embates de classe, previa Max Bill. O que nos leva a concluir que a opção pela arte concreta no Brasil dos anos 50, não só reafirma esse movimento de inserção no capitalismo moderno e industrial, mas também significa optar por uma estratégia cultural universalista. E, sem dúvida, o concretismo brasileiro tinha consciência de seu valor histórico nesse processo. A necessidade de uma arte puramente nacional que tanto marcou nossa formação

\footnotetext{
${ }^{12}$ BRITO, Ronaldo. Neoconcretismo: vértice e ruptura do projeto construtivo brasileiro. São Paulo: Cosac Naify, 1999. Página 37.

${ }^{13}$ BRITO, Ronaldo. Neoconcretismo: vértice e ruptura do projeto construtivo brasileiro. São Paulo: Cosac Naify, 1999. Página 38.
} 
cultural agora dá lugar a um projeto de vanguarda que pretende se desenvolver nas novas bases da pesquisa artística, distante da metafísica da criação, atenta ao processo inventivo da forma.

A recepção da Unidade Tripartida se torna, portanto, um marco da arte concreta no Brasil. Em 1952, somente um após a Bienal que consagrou Bill, surge no país o primeiro grupo de artistas envolvidos nesse projeto de vanguarda: o Grupo Ruptura, integrado por Anatol Wladyslaw (1913-2004), Lothar Charoux (1912-1987), Féjer (1923-1989), Geraldo de Barros (1923-1998), Leopold Haar (1910-1954), Luiz Sacilotto (1924-2003), liderado por Waldemar Cordeiro (1925-1973), realiza exposição no MAM/SP. O grupo redige um manifesto em que a arte é "um meio de conhecimento deduzível de conceitos", e reafirma seu conteúdo objetivo. Em 1956, a primeira Exposição Nacional de Arte Concreta, que reúne além do Grupo Ruptura, um novo grupo, formado pelos alunos do pintor Ivan Serpa (1923-1973), também premiado na Bienal de 51 e professor do Museu de Arte Moderna do Rio de Janeiro, o Grupo Frente, formado por Décio Vieira (1922-1988), Rubem Ludolf (19322010), César Oiticica (1939) e Hélio Oiticica (1937-1980). Participam também, entre outros, Lygia Pape (1927-2004), Lygia Clark (1920-1988), Willys de Castro (1926-1988), Amilcar de Castro (1920-2002) e Franz Weissmann (1911-2005).

\section{1- A arte concreta no Brasil}

Ainda no início do diálogo com a arte concreta, embora fosse atestado todo seu valor universalista, um certo regionalismo, a disputa teórica entre seus seguidores, no Rio e em São Paulo, acabou marcando essa discussão que levaria a uma das mais importantes rupturas do pensamento construtivo na arte brasileira. O germe da disputa entre concretos e neoconcretos que agitaria a década de 60 já se encontrava nas disposições teóricas de grupos como o Grupo Ruptura e o Grupo Frente.

Para o Grupo Ruptura, baseado em São Paulo, a ideia era um projeto de reforma da cultura brasileira: aquela que nos livrasse das antigas compreensões estéticas da arte figurativa e alcançasse a tão almejada dinâmica informacional do trabalho. 

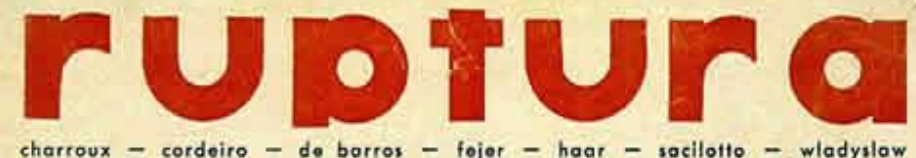

a arte antiga foi grande, quando foi intoligento.

contudo, a nosso inteligência não podo ser a de leonardo.

a história deu um salio qualitativo:

não há mais continuidade!

entăo nós distinguimos

- os que criam formas novas de principios velhos.

- os que criam formas novos do principios novos.

por que?

- naturalismo cientifico da renoscenço - o mb́todo para repre. sentar o mundo extorior (três dimensōes) sôbro um plano (duos dimensóes) - esgotou a sua tarofa histórica.

foi a crise

foi a renovação

hoje o novo pode ser diferenciodo

precisamente do velho. n6s rompe

moscom o velho por isto ofímonion

$$
\text { é o velho }
$$

- Iâdas as variedades - hibridaçóes do naturolismos

- a mera negação do naturolismo, isto 6, - noturalismo "errado" dos crianças, dos loucos, dos "primitivos" dos expressionislos, dos surrealistos, etc. . . ..

- o nầ-figurativismo hedonisto, produto do gêsto gratuito, que busco o mera excitoşăo do prozer ou do desprozer.

$$
\text { é o novo }
$$

- as expressōes bosoadas nos novos principios artisticos:

- tôdas as exporiâncies que tendom ò renovaçâo dos valoros essenciais da arte visual (espaco-tempo, movimento, o materia):

a intuiçāo artistica dotada de principios claros o inteligentos o do grandes possibilldades de desenvolvimento prátice

- conferir à arte um lugar dofinido no quodro do trabalho espiritual contemporáneo, opiniäo, exigindo para o seu juizo conhecimento próvio. opiniäo, exigindo para o seu juiro conhecimento próvio.

arte moderna nฮ̄o b ignoráncia, nós somos contra a ignorancia.

(Manifesto Ruptura, 1952)

Em seu manifesto, o Grupo Ruptura apresenta seu projeto aos moldes dos imperativos que bem cabem a um movimento de vanguarda, mas em sua própria forma já há um apelo à estrutura nos termos da Gestalt: o aproveitamento gráfico, as leis de complementariedade, a dinâmica entre figura e fundo; ainda que este saber gestáltico apareça como uma manipulação de seus princípios, e não como uma prática que o supere ${ }^{14}$ :

\footnotetext{
${ }^{14}$ BRITO, Ronaldo. Neoconcretismo: vértice e ruptura do projeto construtivo brasileiro. São Paulo: Cosac Naify, 1999. Página 45.
} 
Nesse sentido, torna-se uma prática acadêmica - guiada por regras, obcecada principalmente por uma performance ou por uma simples demonstração de postulados. O relacionamento dos artistas concretos com a teoria da Gestalt é de ordem didática, quase uma aprendizagem livresca. ${ }^{15}$

Após a Exposição de Arte Nacional Concreta de 56, a ortodoxia do Ruptura acabaria por gerar a reação do grupo carioca Frente.

Mais aberto, o Grupo Frente permitiu o diálogo com artistas que fugiam a essa ortodoxia concreta, permitindo inclusive pintores como Elisa Martins Silveira (1912-2001), de arte naif, e Carlos Val (1937-), que veio do curso de arte infantil de Ivan Serpa. A presença desses artistas abria o campo de indagações e pesquisas, avesso às regras e às aplicações acadêmicas comuns ao movimento de São Paulo, os cariocas do Frente ganhavam em liberdade. Está aí o germe do neoconcretismo.

No entanto, é importante ressaltar que não se trata de uma simples oposição entre um movimento dogmático e outra vanguarda flexível. O ponto não é esse: primeiro, porque não há nada de errado na busca de uma crescente objetivação dos processos de produção da arte, é um velho acerto de contas com os esquemas de lirismo pré-fabricados de nossa arte modernista; da mesma maneira, a liberdade intuída pelo Grupo Frente não se traduz em um "laissez faire” irresponsável. A disputa se estendia a dois campos: o lirismo e a potência social do trabalho.

A recusa ao uso da cor, por exemplo, em artistas como Waldemar Cordeiro, que alegava o teor literário ${ }^{16}$ do recurso, e os constantes princípios dogmáticos impostos pelo Grupo Ruptura traduzem essa tentativa de extirpar a subjetividade do processo artístico, muitas vezes ainda um ranço de uma batalha travada com a arte moderna brasileira até então oficializada, ou como atesta Brito: um desejo de vingança neurótico, uma edipianização no âmbito da arte.

Olhados com um olho contemporâneo, parecem irrisórios em sua grosseira
(embora ambígua) submissão aos padrões sociais dominantes, em seu fetiche
do tecnológico e em seu ingênuo projeto de superar o subdesenvolvimento por
essa via. Há algo de evidentemente "colonizado" em seu mimetismo do
racionalismo formalista suíço. Não por acaso, é claro, escolhe-se como
paradigma o rarefeito e paradoxalmente delirante racionalismo germânico -
nota-se nesse gesto o desejo de ascender à realidade social de capitalismo
desenvolvido desses países e de suas teorias destinadas em última análise a
preservar essa situação. As vanguardas construtivas na América Latina

15 Id. Ibidem.

${ }^{16}$ Importante ressaltar que, nesse sentido, torna-se evidente o contra exemplo em relação ao Modernismo, marcadamente reconhecido pelo valor literário da obra. O que em certa medida, contribui a uma incorporação apressada e mal executada dos processamentos plásticos do cubismo, por exemplo. 
respondem a este ambíguo desejo: ascender ao mundo desenvolvido para dele tentar se emancipar. Há um infantilismo nessa posição, um desejo de vingança neurótico: atingir o poder do pai para, em seguida, repudiá-lo. ${ }^{17}$

O banimento da subjetividade, a dogmática adaptação à produção industrial e o princípio de uma educação estética que ainda assim recalca sua potência social e acaba por empurrá-lo ao didatismo (principalmente no que se refere à apropriação do saber gestáltico), conferem ao concretismo seu caráter ortodoxo, e também por isso, a necessidade da arte neoconcreta se lançar a uma aventura, a buscar o valor expressivo da arte em detrimento ao mecanicismo concreto. Uma ruptura em relação à vanguarda paulista, uma continuidade do pensamento construtivo. Um passo adiante.

\section{2- O neoconcretismo}

O Manifesto Neoconcreto, assinado em 1959 pelos artistas dissidentes do movimento concreto, que entre eles podemos destacar Lygia Clark (1920-1988), Franz Weissmann (1911-2005) e claro, Amilcar de Castro (1920-2002), é creditado ao poeta e crítico de arte Ferreira Gullar (1930-) e afirmava que "não havia princípios dogmáticos" como no movimento anterior. O movimento era uma dura crítica a essa inquisição concreta contra a subjetividade, um afastamento da teoria da informação e uma aproximação de filosofias voltadas à intersubjetividade, à lógica perceptiva, ao saber gestáltico menos didático e mais especulativo (MerleauPonty). A arte neoconcreta repõe as questões ontológicas no centro das teorizações sobre a linguagem ${ }^{18}$.

\footnotetext{
${ }^{17}$ BRITO, Ronaldo. Neoconcretismo: vértice e ruptura do projeto construtivo brasileiro. São Paulo: Cosac Naify, 1999. Página 51.

${ }^{18}$ BRITO, Ronaldo. Neoconcretismo: vértice e ruptura do projeto construtivo brasileiro. São Paulo: Cosac Naify, 1999. Página 55.
} 
$\Lambda$ cxpressão ncoconcrcto indica uma tomada de posiçăo $\mathrm{cm}$ face da arte não-figurativa "geométrica" (neoplasticismo, construtivismo, suprematismo, escola de Ulm) e particularmente em face da arte concreta levada a uma perigosa cxacerbação racionalista. Trabalhando no campo da pintura, escultura, gravura e literatura, os artistas que participam dessa Exposição Ncoconcreta cncontraram-sc por força de suas experiências, na contingência de rever as posições teóricas adotadas até aqui em face da arte concrcta, uma vez que nenhuma delas "compreende" satisfatoriamente as possibilidades expressivas abertas por estas experiências.

Nascida com o cubismo, de uma reaçẫo à dissolvência impressionista da linguagem pictórica, era natural que a arte dita geométrica se colocasse numa posição diametralmente oposta às facilidades técnicas $\mathrm{c}$ alusivas da pintura corrente. As novas conquistas da física $\mathrm{e}$ da mecânica, abrindo uma perspectiva ampla para o pensamento objetivo, incen

\section{neoconcreto}

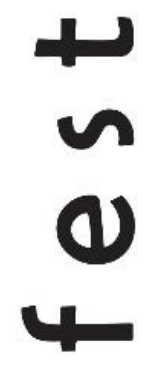

○
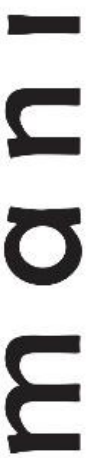

tivaram, nos continuadores dessa revolução, a tendência à racionalização cada vez maior dos processos e dos propósi-

tos da pintura. Uma noção mecanicista de construçâo invadiria a linguagem dos pintores e dos escultores, gerando, por sua vez, reações igualmente extremistas de caráter retrógrado como o realismo mágico ou irracionalista como Dada e o surrcalismo. Não resta dúvida, entretanto, que, por trás de suas tcorias que consagravam a objetividade da ciência e a precisão de mecânica, os verdadeiros artistas - como é o caso, por exemplo, de Mondrian ou Pevsner - contruíam sua obra $\mathrm{c}$, no corpo-a-corpo com a expressăo superaram, muitas vezes, os limites impostos pela teoria. Mas a obra desses artistas tem sido até hoje interpretado na base dos princípios teóricos, que essa obra mesma negou. Propomos uma reinterpretação do neoplasticismo, do construtivismo e dos demais movimentos afins, na base de suas conquistas de expressão e dando prevalência à obra sobre a teoria. Se pretendemos entender a pintura de Mondrian pelas suas tcorias, scremos obrigados a escolher entre as duas. Ou bem a profecia de uma total integração de arte na vida cotidiana parece-nos possivel -e vemos na obra de Mondrian os primeiros passos nesse sentido - ou cssa integração nos parece cada vez, mais remota e a sua obra se nos mostra frustrada. Ou

(Manifesto Neoconcreto, 1959) bcm a vertical c a horizontal são mesmos os ritmos fundamentais do universo e a obra de Mondrian é a aplicação desse principio universal ou o princípio é falho e sua obra se revela fundada sobre una ilusão Mas a verdade é que a obra de Mondrian ai está, viva e fecunda, acima dessas contradições teóricas. De nada nos servirá ver em Mondrian e desfrutar da superfícic, do plano c da linha, se não atentamos para o novo espaço que essa destruição construiu.

O mesmo se pode dizer de Vantangerloo ou de Pevsncr. Não importa que cquações matemáticas estcjam na raiı de uma escultura ou de um quadro de Vantangerloo, desde que só à experiência direta da perecpção a obra cntrega a "significação" de scus ritmos c de suas corcs. Se Pevsner partiu ou não de figuras de geometria descritiva é uma questão scm interesse em face do novo espaço que as suas esculturas fazem nascer $\mathrm{c}$ da expressão cósmico-orgânica que, através dele, suas formas revelam. Terá interesse cultural específico determinar as aproximações entre os objetos artísticos e os instrumentos científicos, entre a intuição do artista e o pensamento objetivo do físico e do engenheiro. Mas, do ponto-devista estético, a obra começa a interessar precisamente pelo que nela há que transcende essas aproximações

Se, por um lado, a arte concreta parte do contraexemplo modernista na afirmação de seu projeto construtivo, os neoconcretos, uma dissidência dentro da própria vanguarda concreta se constitui a partir das críticas ao que consideravam o radicalismo da arte concreta de São Paulo.

Já no início de Manifesto, o projeto construtivo é colocado em movimento, deixando claro o desdobramento de determinados preceitos da arte concreta. Uma 
tomada de posição frente ao que consideravam uma "perigosa exacerbação racionalista" 19 .

No que se localiza historicamente como um desdobramento dento do próprio projeto construtivo inaugurado no Brasil a partir da arte concreta, os neoconcretos questionam:

\begin{abstract}
Nascido com o cubismo, de uma reação à dissolvência impressionista da linguagem pictórica, era natural que a arte dita geométrica se colocasse numa posição diametralmente oposta às facilidades técnicas e alusivas da pintura corrente. As novas conquistas da física e da mecânica, abrindo uma perspectiva ampla para o pensamento objetivo, incentivariam, nos continuadores dessa revolução, a tendência à racionalização cada vez maior dos processos e dos propósitos da pintura. Uma noção mecanicista de construção invadiria a linguagem dos pintores e dos escultores, gerando, por sua vez, reações igualmente extremistas, de caráter retrógrado como o realismo mágico ou irracionalista como Dada e o surrealismo. Não resta dúvida, entretanto, que, por trás de suas teorias que consagravam a objetividade da ciência e a precisão da mecânica, os verdadeiros artistas - como é o caso, por exemplo, de Mondrian ou Pevsner - construíam sua obra e, no corpo-a-corpo com a expressão, superaram, muitas vezes, os limites impostos pela teoria. ${ }^{20}$
\end{abstract}

A passagem supracitada, afora o teor combativo (comum ao discurso de vanguarda), ressalta dois aspectos fundamentais da crítica neoconcreta ao movimento paulista: o mecanicismo e o valor da expressão.

Por mecanicismo, leia-se uma certa apropriação acadêmica dos preceitos da arte construtiva, a radicalização teórica que atribuía ao trabalho de arte um caráter exclusivamente informacional. Como se ao intento de aproximar arte e vida, a essa sociedade recém-industrializada, além da incorporação dos materiais industriais, existisse a necessidade de uma educação estética. Aos neoconcretos, tais objetos de arte perdem expressividade, o valor informacional se sobrepõe a intersubjetividade, à alteridade do espectador. É preciso mais do que isso para a afirmação da arte construtiva no Brasil, especialmente em um país onde o modernismo se caracterizou pelo caráter estatal, caberia ao neoconcretismo ganhar ares públicos - não necessariamente no que se refira à mercantilização de seus trabalhos, o que posteriormente acabaria acontecendo com alguns de seus artistas, como por exemplo, Helio Oiticica e Lygia Clark, mas era preciso um desdobramento teórico inclusive, a passagem da Gestalt para a teoria da recepção.

\footnotetext{
${ }^{19}$ Manifesto neoconcreto (1959) disponível no site http://www.mariosantiago.net/Textos\%20em\%20PDF/Manifesto\%20neoconcreto.pdf 20 Ibidem
} 
Dez anos antes do Manifesto Neoconcreto, o crítico de arte Mario Pedrosa, a quem, por justiça, Gullar se reconhece como um tributário teórico, escreveu Da natureza afetiva da forma ${ }^{21}$. Àquela altura, Pedrosa inseria-se ainda no debate entre a arte figurativa (dominante no Brasil) e a arte abstrata, e ainda que sua tese não fosse (ao menos explicitamente) em defesa da abstração, ela em princípio rejeita "a percepção que seja precedida por um ato virtual de reconhecimento", o que corresponderia ao reconhecimento de objetos úteis ${ }^{22}$. Nossa apreensão afetiva no encontro com esses objetos atesta sua existência preliminar, o objeto sensível - reconhecido, é incapaz de inaugurar-se em seu próprio acontecimento.

A urgência da tese de Pedrosa na análise sobre a teoria da Gestalt e até mesmo o posterior excesso racionalista dos concretos é perfeitamente compreensível em um cenário em que a arte figurativa dominava e compreendia a figuração, esta sim, como um "especializado" da forma ${ }^{23}$. Não era essa a preocupação de Pedrosa. O crítico debruçava-se, acima de tudo, sobre o fundamento do próprio objeto, seu aspecto ontológico, sua capacidade intersubjetiva: o objeto realizado é o ponto terminal da ação do artista, mas o ponto de partida do apreciador ${ }^{24}$. Está aberto o espaço para uma teoria da recepção e é dela que Gullar parte.

\begin{abstract}
Não importam que equações matemáticas estão na raiz de urna escultura ou de um quadro de Vantongerloo, desde que só à experiência direta da percepção a obra entrega a "significação" de seus ritmos e de suas cores. Se Pevsner partiu ou não de figuras da geometria descritiva é uma questão sem interesse em face do novo espaço que as suas esculturas fazem nascer e da expressão cósmicoorgânica que, através dele, suas formas revelam. Terá interesse cultural específico determinar as aproximações entre os objetos artísticos e os instrumentos científicos, entre a intuição do artista e o pensamento objetivo do físico e do engenheiro. Mas, do ponto de vista estético, a obra começa a interessar precisamente pelo que nela há que transcende essas aproximações exteriores: pelo universo de significações existenciais que ela a um tempo funda e revela. ${ }^{25}$
\end{abstract}

\footnotetext{
${ }^{21}$ Escrito em 1949, a tese de Pedrosa se coloca não só antes, como para além das querelas entre as vanguardas concreta (São Paulo) e neoconcreta (Rio de Janeiro). Seu texto situa o impacto da teoria da Gestalt na arte construtiva brasileira. Ver em MARTINS, Sergio Bruno. "Entre a fenomenologia e o historicismo: Amílcar de Castro enquanto ponto-cego da teoria do não-objeto" https://www.academia.edu/24061256/Entre_a_fenomenologia_e_o_historicismo_Amilcar_de_C astro_enquanto_ponto_cego_da_teoria_do_n\%C3\%A3o-objeto

22 Ibidem

23 Ibidem

24 Ibidem

${ }^{25}$ Manifesto neoconcreto, 1959.

http://www.mariosantiago.net/Textos\%20em\%20PDF/Manifesto\%20neoconcreto.pdf
} 
Gullar mantém sua crítica ao mecanicismo da arte concreta inclusive ao que considera a psicologia causalista da Gestalt, cujos preceitos, para os neoconcretos, ainda soavam como uma teoria importada pelos concretos e aqui radicalizada ao banir a transcendência da obra de arte. Ao ressaltarem o universo de significações existenciais que o objeto, ou quasi corpus, como preferem, ao mesmo gesto funda e revela, os neoconcretos atestam seu valor fenomenológico e ampliam a discussão para o campo da recepção. Nesse sentido, o regime aberto de experiência defendido pelo poeta se aproxima das teorizações de Pedrosa sobre o pensamento gestáltico, ainda que em primeiro plano o refute, talvez pela necessidade de um discurso de vanguarda combativo até então ao radicalismo concreto, a contribuição de $D a$ natureza afetiva das formas é evidente para o desenvolvimento do arcabouço teórico dos neoconcretos.

De acordo com o Manifesto, o apego ao cientificismo e às atitudes positivistas, muitas vezes presente na vanguarda concreta, é o que impede a reposição de questões como a expressão no trabalho de arte. A aproximação entre arte e vida, não se daria somente na incorporação dos elementos de uma sociedade moderna e industrializada, não se sustenta na informação, mas no que a partir do trabalho se deixa mobilizar em subjetividade e transcendência. Como se afora a razão matemática, a geometria se sensibilizasse.

A geometria sensível dos neoconcretos não é a negação da forma e nem a vontade de estetizar a ordem racional, como acreditavam os concretismos suíço e, posteriormente, o brasileiro; mas a capacidade positiva dessa forma se envolver com o espaço, reconhecendo que os conceitos como forma, espaço, tempo e estrutura, na linguagem das artes, estão intimamente ligados a uma significação existencial e afetiva. Não é o homem máquina entre máquinas, e sim subjetividade, diálogo e capacidade de expressão.

Acreditamos que a obra de arte supera o mecanicismo material sobre o qual repousa, não por alguma virtude extraterrena: supera-o por transcender essas relações mecânicas (que a Gestalt objetiva) e por criar para si uma significação tácita (Merleau-Ponty) que emerge nela pela primeira vez. Se tivéssemos que buscar um símile para a obra de arte não o poderíamos encontrar, portanto, nem na máquina nem no objeto tomados objetivamente, mas como S.Langer e 
W. Wleidlé, nos organismos vivos. Essa comparação, entretanto, ainda não bastaria para expressar a realidade específica do organismo estético. ${ }^{26}$

Um organismo vivo, imune a ser apreendido em sua objetivação, assume a expressão de realidades humanas ao vocabulário "geométrico" mobilizando o espaço, envolvendo-o e inaugurando-se, sempre presente ao impulso que o gerou, sempre atento ao próprio ato da espacialização que sua necessidade expressiva manifesta.

\begin{abstract}
Entenda-se por espacialização da obra o fato de que ela está sempre se fazendo presente, está sempre recomeçando o impulso que a gerou e de que ela era já a origem. E essa descrição nos remete igualmente à experiência primeira - plena - do real, é que a arte neoconcreta não pretende nada menos que reacender essa experiência. A arte neoconcreta funda um novo "espaço" expressivo. ${ }^{27}$
\end{abstract}

Há, portanto, no neoconcretismo uma clara crítica a apropriação meramente virtual do espaço e ao pensamento mecanicista em arte, e até mesmo uma preocupação com a ideia de procedimentos "abertos" da ciência contemporânea (as especulações em torno da geometria não-euclidiana, a atração que a cinta de Moebius exercia sobre artistas como Lygia Clark e Lygia Pape). Se por um lado, o concretismo é a fase dogmática, na necessidade de se opor à arte modernista, portanto, a fase de implantação de uma série de processamentos plásticos e teóricos mal incorporados pelo seu contraexemplo; o neoconcretismo é o período de ruptura em relação ao pensamento ortodoxo concreto, fruto, sobretudo, dos choques da adaptação local. Um retorno ao humanismo - ainda que nada tradicionalista - em oposição ao cientificismo concreto.

\footnotetext{
${ }^{26}$ Manifesto neoconcreto, 1959. Em Manifesto neoconcreto, 1959. http://www.mariosantiago.net/Textos\%20em\%20PDF/Manifesto\%20neoconcreto.pdf

27 Manifesto neoconcreto, 1959. Em Manifesto neoconcreto, 1959. http://www.mariosantiago.net/Textos\%20em\%20PDF/Manifesto\%20neoconcreto.pdf
} 


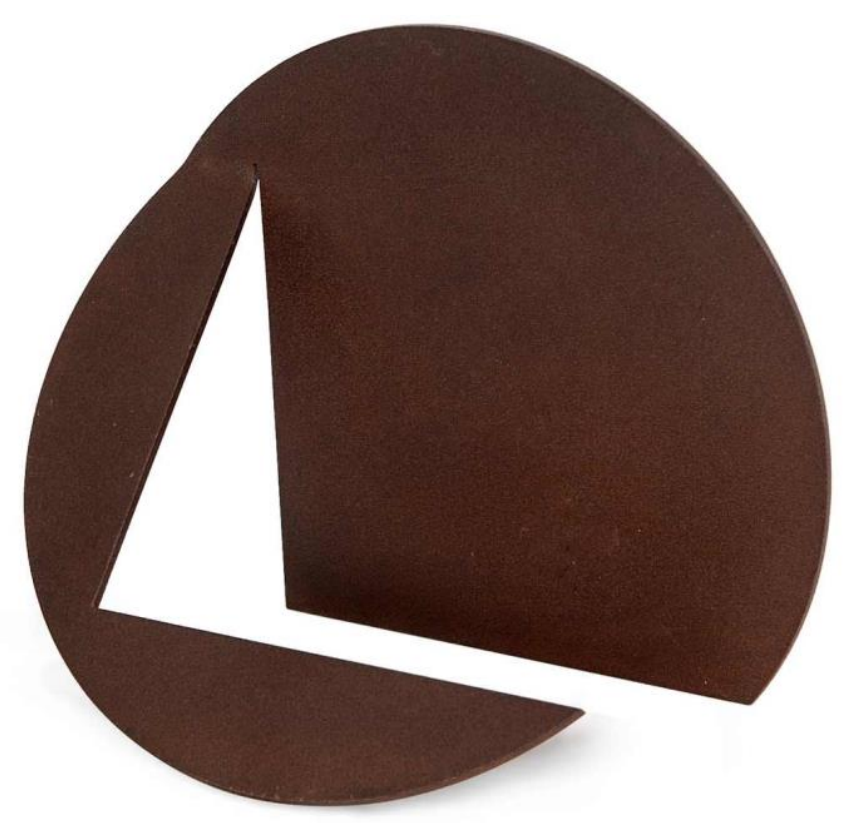

(Sem título. Amilcar de Castro, 1998) [7]

Amilcar ao se aproximar da arte neoconcreta reafirma certos valores plásticos que investigava desde os tempos da Escola Guignard, mas por outro lado, reafirma sua própria potência poética, e necessariamente individual, na manutenção de suas premissas existenciais e incrivelmente consistentes.

Escolhendo sempre o mesmo material, partindo quase sempre da mesma escala de confronto, uma escultura que se constrói a partir do corte e/ou da dobra é capaz de proporcionar uma experiência rigorosamente reversa à simplicidade e clareza de seu método. A matéria baliza um espaço, e o que nessa interseção emerge é um outro espaço completamente novo e original: o espaço reificado de suas esculturas. A densidade existencial (da corrosão) de seu material, o aço cor-ten, a tensão resistente de suas dobras. 


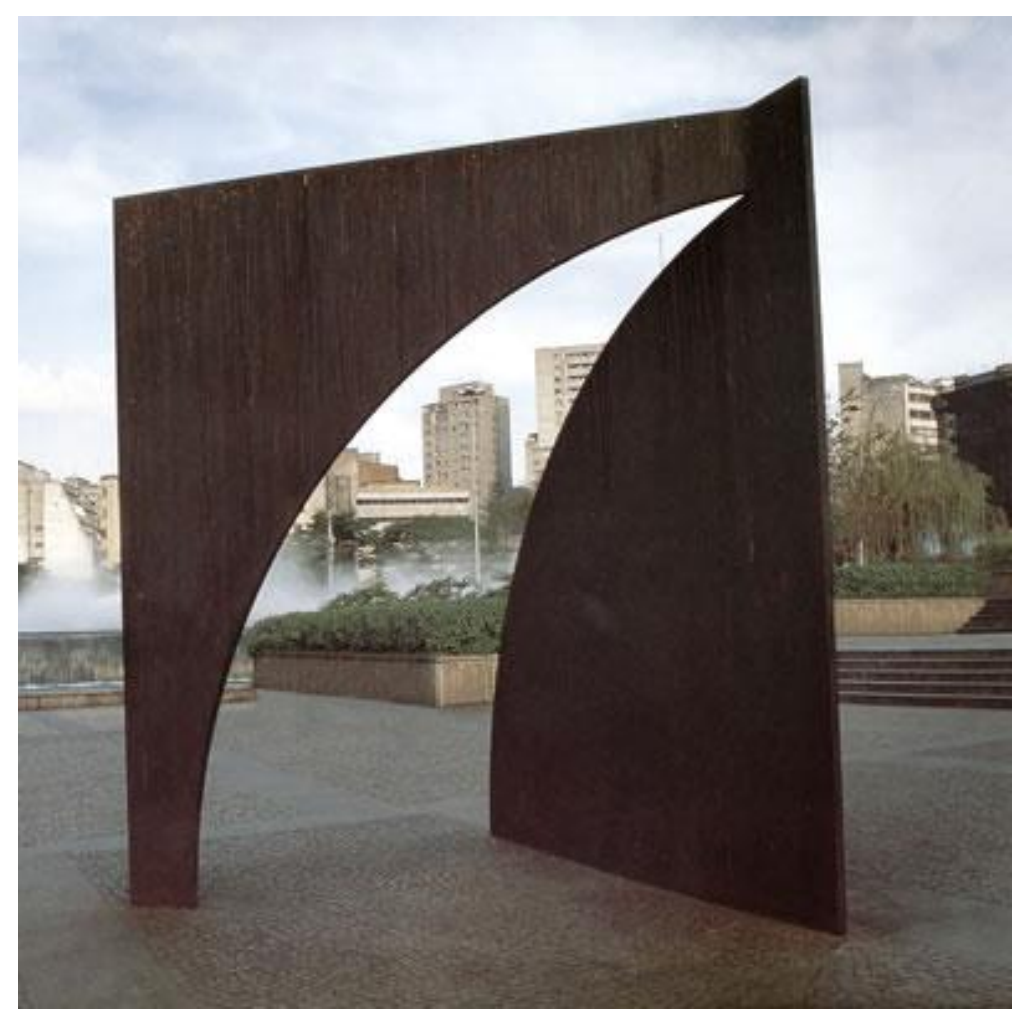

(Sem título, Amilcar de Castro, 1979) [8]

Em suas esculturas o espaço é qualificado, enriquecido pela criação de regiões diferenciadas e complementares. Amilcar é um escultor construtivista e isso é evidente não só em seu método, mas, em consonância a seus pares, no que se refere ao material trabalhado. A assimilação do material industrial somada às limitações do mercado brasileiro e sua poética justificativa sobre a oxidação levam ao aço cor-ten. Ao incluir a resistência do aço à estrutura das obras, evidente na tensão de suas dobras ${ }^{28}$, Amilcar acrescentou um elemento inédito à formalização construtiva. As torções geradas pela dobra, e que organizam a escultura, introduzem diferenças na homogeneidade das lâminas de aço. Nas dobras, o aço se mostra mais tensionado, o que progressivamente abranda à medida que tende a um novo plano.

(...)Sobretudo nas esculturas de grandes dimensões, esse movimento de diferenciação das superfícies se transpunha para o espaço que elas modulavam, como se a força empregada nas dobras fosse transmitida a ele.

Em lugar de uma espacialidade determinada por um corpo humano entendido de forma limitada e instrumental - alto e baixo, direita e esquerda -, elas nos punham em contato com dimensões muito mais plurais e conturbadas,

${ }^{28}$ NAVES, Rodrigo; MESQUITA, Tiago. Amilcar de Castro, Mira Schendel, Sergio Camargo, Willys de Castro/ Rodrigo Naves e Tiago Mesquita. São Paulo: Instituto de Arte Contemporânea - IAC, 2006. 
surpreendentes e expansivas. $\mathrm{O}$ ar que atravessava as aberturas das obras ou que incidia sobre as chapas magnetizava-se pelo contato com a tensão das dobraduras $^{29}$

A escolha do aço, nítida incorporação do elemento industrial, para além de um imperativo de vanguarda, a Amilcar se justifica em sua poética. Suas obras em comparação, por exemplo, com outros dois contemporâneos - Lygia Clark e Franz Weissmann - em relação a escolha e o trato com o material nos permite compreender essa particularidade.

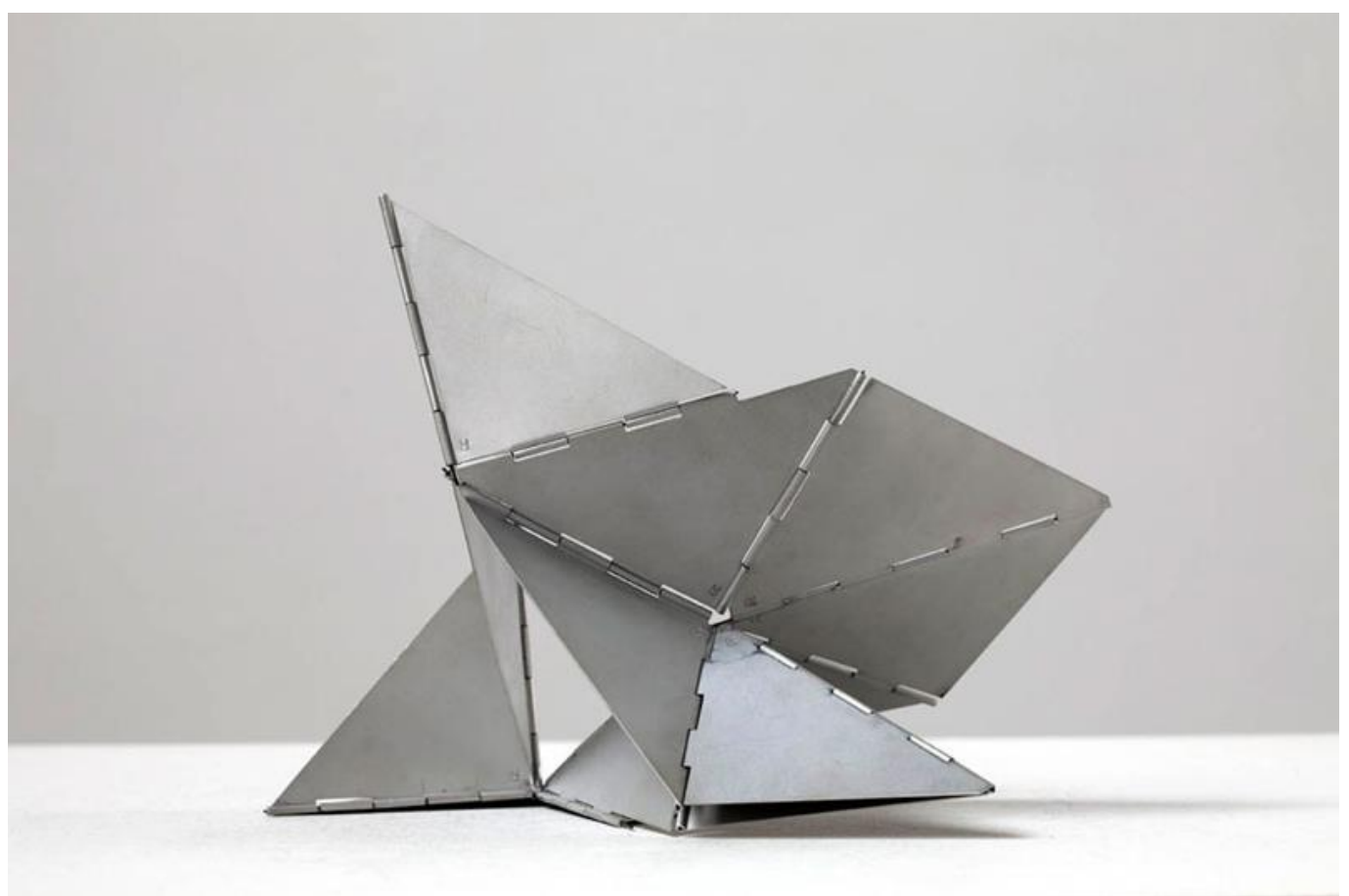

(Bichos, 1960 - Lygia Clark) [9]

A série "Bichos" de Lygia Clark, exposta pela primeira vez em 1960 e constituída de chapas metálicas articuladas por dobradiças, já insere na obra da artista a participação do espectador, núcleo de seu projeto artístico. Esse aspecto mais orgânico de seu trabalho confirma a aproximação pretendida entre arte e vida que pretendia o neoconcretismo.

Pensados em uma escala possível ao manuseio, os "bichos" ultrapassam o limite da contemplação e convidam o espectador à interação, a participação direta,

${ }^{29}$ Ibidem 
o que pouco a pouco vai suprimindo o próprio objeto em uma operação que ao passo que reifica sua condição de arte, abala conceitualmente a noção de objeto.

Ferreira Gullar ao analisar alguns trabalhos neoconcretos elabora a tese de que o produto daquela equação entre o fazer artístico e o convite, a relação, a intersubjetividade estabelecida, seria um não-objeto, algo que já não coubesse mais à mera contemplação (diferente de uma tela, um objeto de arte ao qual estamos diante, os não-objetos exigem que estejamos mais que diante de seu aparecimento, mas participantes, relacionais, construtores de seus desdobramentos fenomenológicos), ao mesmo tempo que não possuem qualquer outra utilidade usual, cotidiana. Não podem ser compreendidos apenas como objetos exatamente porque já correspondem a uma relação subjetiva que extrapola a percepção passiva de seu acontecimento. Nas palavras do poeta:

\begin{abstract}
A expressão não-objeto não pretende designar um objeto negativo ou qualquer coisa que seja o oposto dos objetos materiais com propriedades exatamente contrárias desses objetos. O não-objeto não é um antiobjeto mas um objeto especial em que se pretende realizada a síntese de experiências sensoriais e mentais: um corpo transparente ao conhecimento fenomenológico, integralmente perceptível, que se dá à percepção sem deixar resto. Uma pura aparência. ${ }^{30}$
\end{abstract}

Exatamente o que fundamenta a série de Lygia Clark: a pura aparência, múltiplas possibilidades sobre esse mesmo objeto especial, que se apresenta em sua experimentação, no convite à aventura topológica e nos espaços conquistados pela participação. Características que a afastam, ao mesmo tempo que aparece como um didático contraponto para entender a abordagem do trabalho de Amilcar de Castro em relação a essas questões.

Se por um lado, a incorporação de elementos da sociedade industrial em ambos seja marca e índice da vanguarda ao qual pertenciam, por outro, a escolha desse material obedecia a critérios estritamente ligados à pesquisa do artista. As chapas de alumínio da série de Clark possuem a leveza necessária ao manuseio, ao livre desdobramento sobre o espaço, placas que se articulam a partir de dobradiças que funcionam como um convite à participação. $\mathrm{O}$ impulso frente aos seus nãoobjetos é o de eliminar a possível tensão que exista entre a relação sujeito e objeto; suas dobradiças indicam o movimento e a dinâmica que se estabelece entre o

\footnotetext{
${ }^{30}$ GULLAR, F. Teoria do não-objeto (1960). In AMARAL, A. (Org) Projeto construtivo brasileiro na arte (1950-1962). São Paulo: Pinacoteca do Estado, 1977
} 
espectador e a construção do plano a partir de sua participação traduz a força pulsional de sua série. Pulsional no que podemos entender enquanto um processo que parte de um comportamento inquieto, que visa apaziguar a tensão corporal/conceitual gerada pela fonte, o objeto, ou melhor, o não-objeto. A obra emerge a minha participação e a minha participação amplia o próprio fazer artístico.

Já os trabalhos de Amilcar, até mesmo os feitos em menor escala (embora nunca voltado a uma participação direta), são feitos em aço inoxidável. A densidade é muito maior, a resistência da matéria é visível, as possibilidades de movimento e dobra são quase como milagres. Se as dobradiças de Lygia Clark reintegram a partir de uma unidade de articulação suas placas metálicas, as dobras de Amilcar de Castro salientam ainda mais a tensão entre as placas. A conquista do plano não surge como uma dinâmica lúdica de movimentos, mas tensionada, em resistência, fruto de um árduo esforço e de uma geometria inventiva e sensível. A diferença entre os dois artistas e importância da participação do espectador é gritante:

\begin{abstract}
Cada "Bicho" é uma entidade orgânica que se revela totalmente dentro de seu tempo interior de expressão. [...] é um organismo vivo, uma obra essencialmente atuante. Entre você e ele se estabelece uma integração total, existencial. Na relação que se estabelece entre você e o "Bicho" não há passividade, nem sua nem dele. Acontece uma espécie de corpo a corpo entre duas entidades vivas. ${ }^{31}$
\end{abstract}

Eu não estou interessado nisso e minha proposta não é essa. Participação do espectador, para mim, é secundária e boba. Boba mesmo, não é isto que eu estou querendo. [...] Não existe participação do espectador. Já escrevi sobre isso. $\mathrm{O}$ espectador só participa daquilo que o autor quer. Então, ele acaba ficando que nem menino aprendendo a andar naquele chiqueirinho. Só anda onde o chiqueirinho deixa ele ir. Não faz nada, não inventa nada [...] $\mathrm{O}$ espectador sou eu. Eu gostando, garanto. ${ }^{32}$

\footnotetext{
${ }^{31}$ CLARK, Lygia. “1960: Os Bichos” - Texto de Lygia Clark no catálogo LYGIA CLARK.

32 Entrevista com Amilcar de Castro em 1999 citada em Ver em ALVES, José Francisco. Amilcar de Castro: Uma retrospectiva. Pref. Paulo Sérgio Duarte. Porto Alegre, Fundação Bienal de Artes Visuais do Mercosul, 2005. Página 20
} 


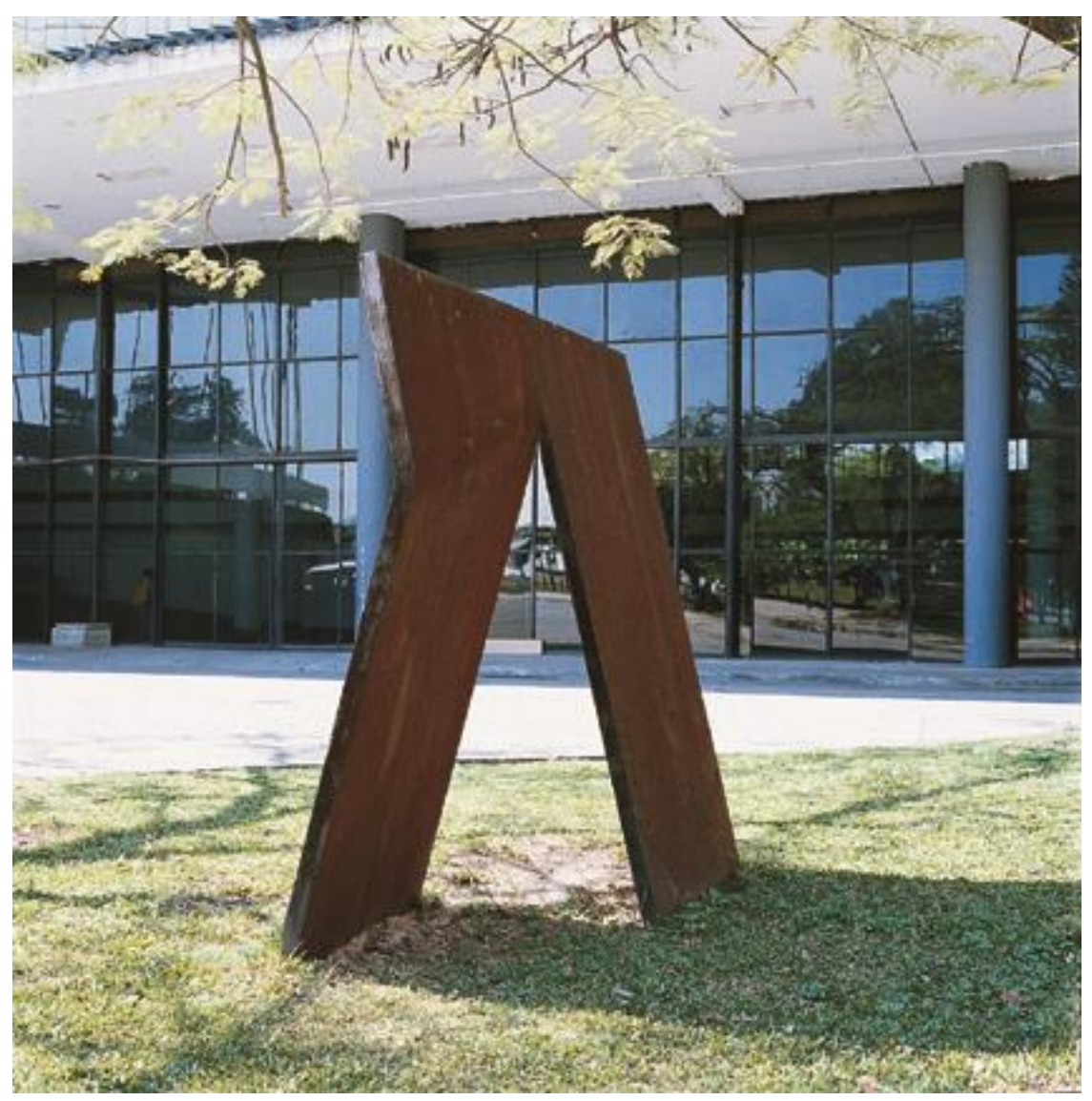

(Sem título, 1970 - Amilcar de Castro) [10]

A escolha do aço, dada as limitações do mercado brasileiro à época em ter chapas maiores, expressa essa densidade proposta pelo peso do próprio material, incapaz de ser manuseado, pelo contrário, o embate com suas esculturas de corte e dobra não impulsionam a participação, mas o confronto, a compreensão demorada, o tempo mítico da fruição, a especulação sobre a conquista do espaço. O jogo de luz sobre a chapa, a tensão luminosa de suas dobras.

Diferente do alumínio, em que a penetração da luz se dá de maneira menos intensa, o aço de Amilcar está disposto à luz e ao espaço da mesma maneira que está ao tempo. Por isso não as pintar, não as edulcorar. Se a luminosidade sobre a chapa estimula o antagonismo entre as placas e sobre sua dobra intensifica a tensão, se o espaço é conquistado por suas esculturas, o tempo marca-se na oxidação de suas chapas, aumenta ainda mais a carga existencial da obra, inclui a duração.

Convém lembrar, porém, que no âmbito de um movimento comprometido com a leitura construtiva da arte pós-cubista, chegar a introduzir Bergson - com sua doutrina intuicionista e sua ideia de tempo como duração - é quase um escândalo. E, no entanto, era de alguma maneira pertinente ao projeto 
neoconcreto: servia e estava associado à proposta de "ativar" o relacionamento do sujeito com o trabalho e permitir múltiplas possibilidades de leitura, "abertas" no tempo. (...) as esculturas de Amilcar de Castro, por exemplo, trabalhavam o tempo como virtualidade - tratava-se de algo assim como deixar em suspenso o "tempo" de produção de modo a permitir a intervenção do espectador quase no sentido de completar os trabalhos, recriá-los, lê-los, a cada vez de maneira diversa, viver os instantes de sua produção. ${ }^{33}$

A vanguarda neoconcreta e seu desejo de sensibilizar a geometria, prescrever, de certo modo, uma leitura dramática, existencial. O trabalho não é pensado enquanto processo informacional, mas como proposição de vivências. $\mathrm{O}$ tempo neoconcreto é fenomenológico, aproxima arte e vida, repotencializa o vivido. Lygia Clark, à força libidinal de seus "bichos”, convoca o outro à participação, seus não-objetos estão à mão da criatividade, da intersubjetividade. Amilcar de Castro não convida, suas esculturas se impõem, confrontam, aparecem, mobilizam um processo descontínuo de leitura que dá margem a uma atitude essencialmente envolvida por parte do observador. No aço de Amilcar, o tempo é índice e rastro.

\footnotetext{
${ }^{33}$ BRITO, Ronaldo. Neoconcretismo: vértice e ruptura do projeto construtivo brasileiro. São
} Paulo: Cosac Naify, 1999.Páginas 79-80. 


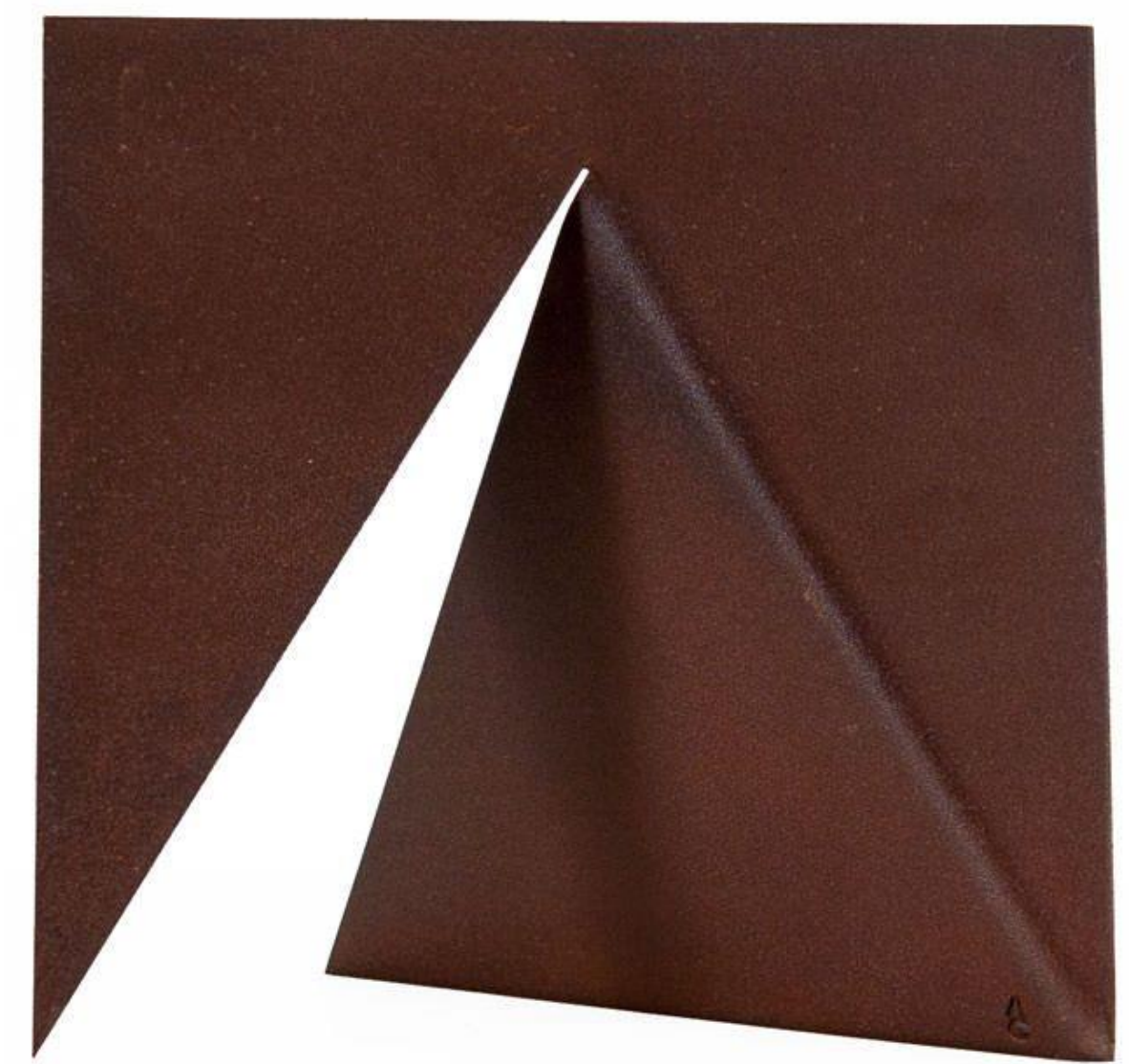

(Sem título, 1970- Amilcar de Castro) [11]

Outra marca de sua densidade está no próprio envolvimento da escultura no espaço, ou melhor em seu auto envolvimento. Em esculturas, por exemplo, como a que está nos jardins do Tribunal de Contas da União em Brasília é gritante esse desdobramento topológico. Experimentando, a partir do plano, uma geometria nãoeuclidiana que toma as ideias de dentro e fora como partes de um mesmo conjunto, o indecidível polígono construído por Amilcar tem a inventividade construtiva da forma e o impulso estrutural de uma obra que não permite restos.

Para melhor compreender essa relação com o espaço torna-se importante trazer ao debate outro artista contemporâneo de Amilcar de Castro e que em uma apropriação completamente diferente em relação à topologia acaba se tornando um contraponto para a nossa análise: Franz Weissmann (1911-2005).

Amilcar de Castro e Franz Weissmann já se conheciam desde a época em que o artista mineiro decidiu vir para o Rio de Janeiro, foi inclusive com o austrobrasileiro que Amilcar teve suas primeiras aulas de escultura, ainda figurativa. Mais tarde, seriam companheiros de vanguarda. 


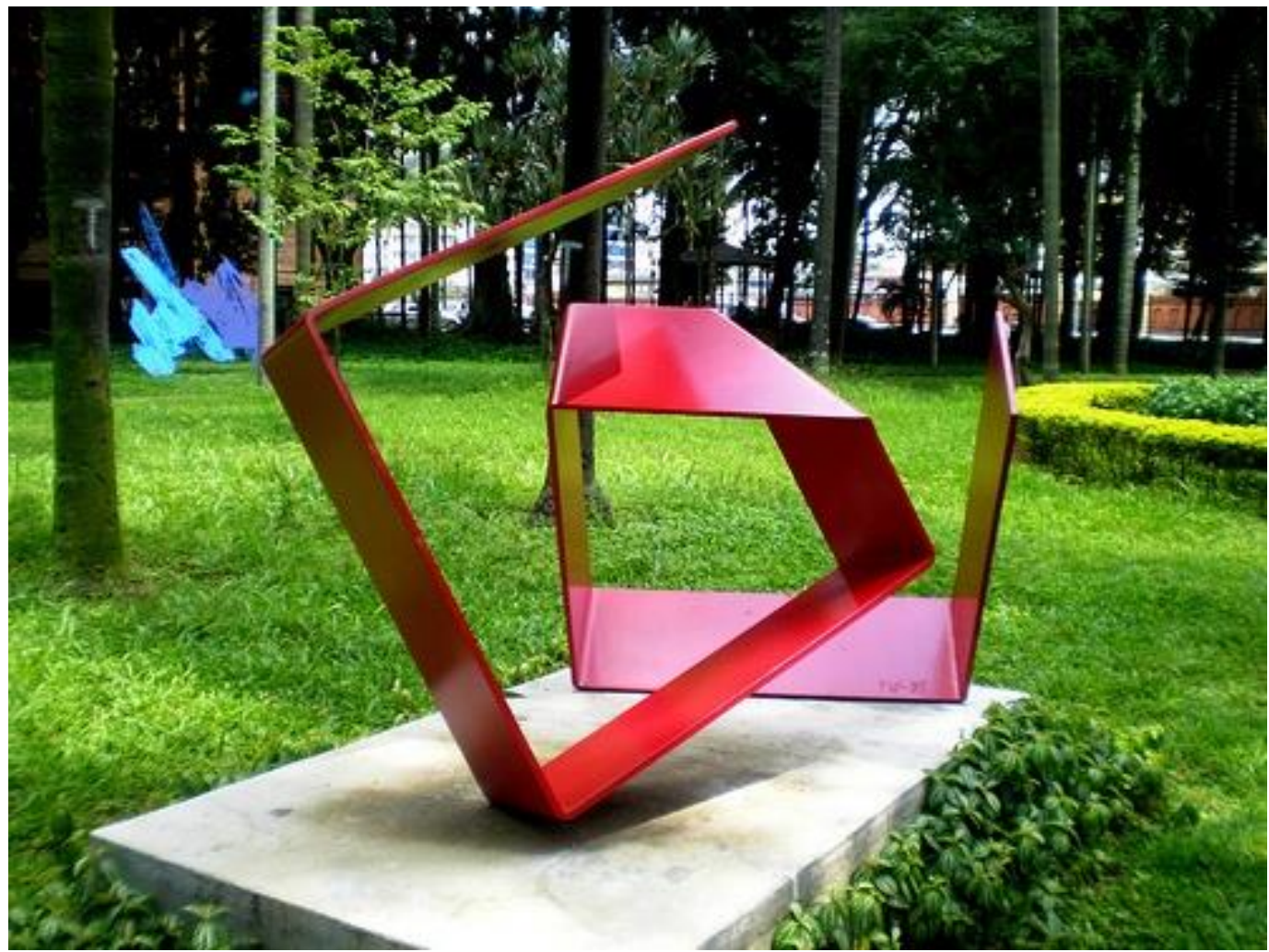

(Fita, 1985 - Franz Weissmann) [12]

Tanto Amílcar de Castro quanto Franz Weissmann partem da estrutura planar rumo à experiência escultórica. Articulações sobre um raciocínio estrutural que leva a uma compreensão do espaço como o próprio ato de espacializar. No entanto, as semelhanças basicamente param por aí.

Weissmann apresenta uma clara vocação a uma demonstração livre dessa fluência geométrica. Suas esculturas partem do plano fluídas, leves. Suas chapas têm cor, é lírico o seu aço. Enquanto podemos compreender a obra de Amílcar, principalmente a partir de suas esculturas de corte e dobra, como o auto envolvimento de um trabalho que acompanha de certa forma uma inércia (não obstante, provinda de seu peso existencial), o que já em Weissmann é a opção pelo movimento, o facetado movimento de uma fita.

Não existe forma fechada para Weissmann, é como se não pudesse existir uma figura geométrica senão em movimento e transformação. O espaço é a pulsação de espaço. Fluida, permeável, a própria matéria está presente para ser 
vazada e atravessada por manobras que liberam o ar-livre. Sua obra nega qualquer ideia estática de monumento em prol da celebração do transitório, do fugaz. É como se eternamente suas fitas fossem se desdobrando, inaugurando e conquistando novos espaços, lançando-se, por assim, a uma aventura do provisório, o inesperado, o por vir.

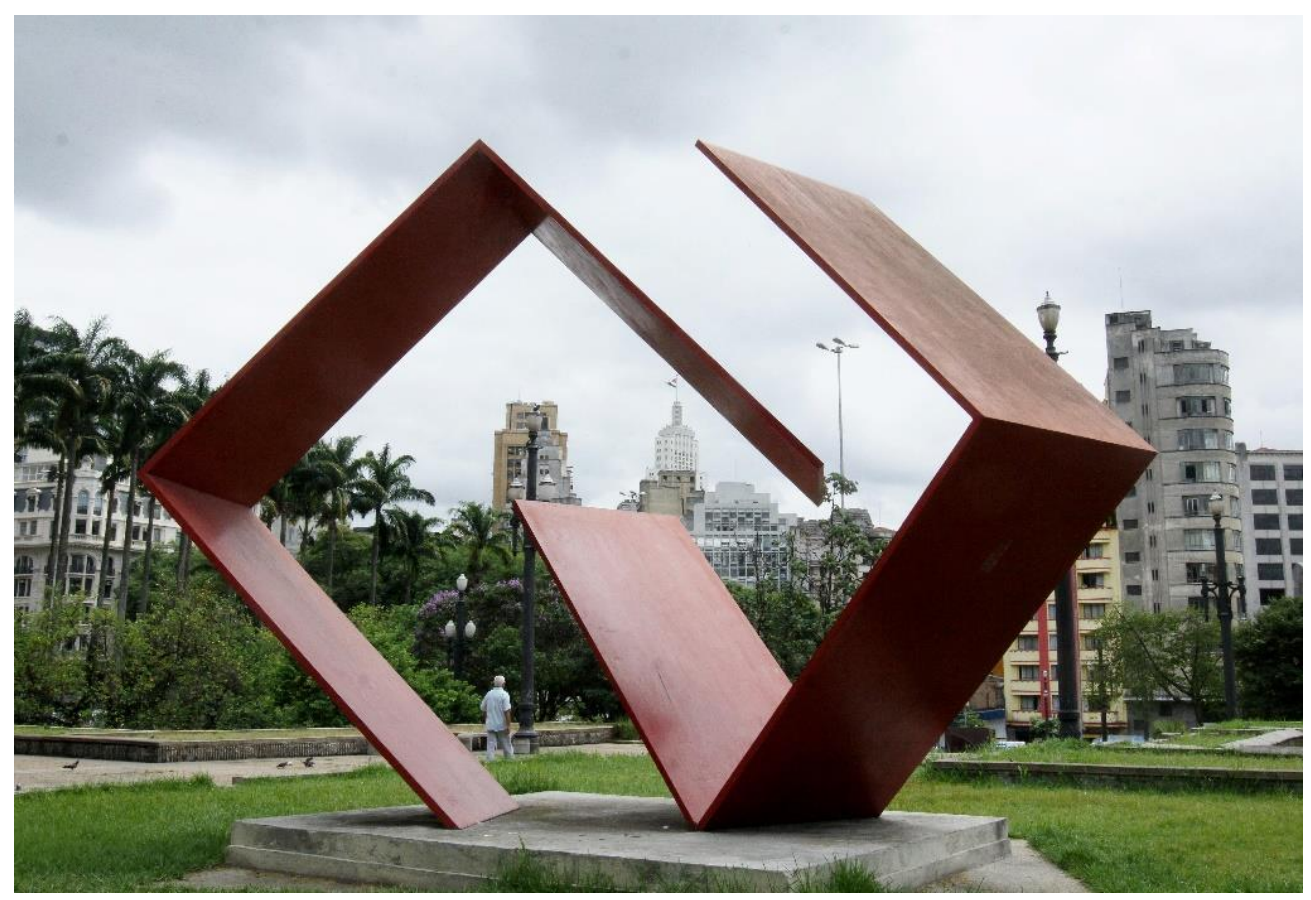

(Diálogo, 1979 - Franz Weissmann) [13]

Em esculturas como "Diálogo", de 1979, o valor topológico da obra é evidente: a escultura se auto envolve, interagindo cheio e vazio, ao ponto de integrar, ou a partir do próprio raciocínio estrutural, deixar emergir este vazio, que sob o signo da negação afirma-se como todo na obra. Um todo provisório, mutável em seu movimento plástico e livre. Além de afirmar sua intensa vocação pública.

Amilcar, apesar da mesma vocação, e de não abordar o espaço, mas experimentá-lo, possui uma potência poética e uma sintaxe topológica próprias. Diferente das esculturas de Weissmann, Amílcar mantém a escala coloquial, exigindo o embate um a um. Seus trabalhos nos pesam como em sua própria espessura. Sua relação com o espaço é sempre uma relação de conquista, como se o impulso estrutural da matéria fosse o impulso existencial do próprio artista. Seu raciocínio estrutural, que parte do plano, tem no corte (sempre a quente, por isso 
incapaz de manter a exatidão geométrica, quase como um rompimento à inércia geométrica) "o recurso de estruturação da forma final, assumida na passagem de sua condição bidimensional para a condição tridimensional” ${ }^{34}$. A dobra como sustentação, a conquistar a tridimensionalidade, o cheio e o vazio - componentes da escultura.

Tanto Weissmann quanto Amílcar, em diferentes escalas e matérias, trabalham sua linguagem construtiva no limite geométrico do aparecimento da forma, a conquista do espaço é a conquista de uma nova forma de se pensar o espaço, de abri-lo, como uma de suas frestas: espaços de passagem que acolhem, liberam o ar, a luz, o fluir das pessoas.

Por isso a importância de sua vocação pública, de suas esculturas que ainda em sua fria matéria industrial nos abraçam, que na mobilização de seu próprio espaço evidencie o vazio como parte integrante e deixe emergir nossa própria alteridade, frente ao fenômeno, ao aparecimento da forma, que nos confronta e, também como nós, perece.

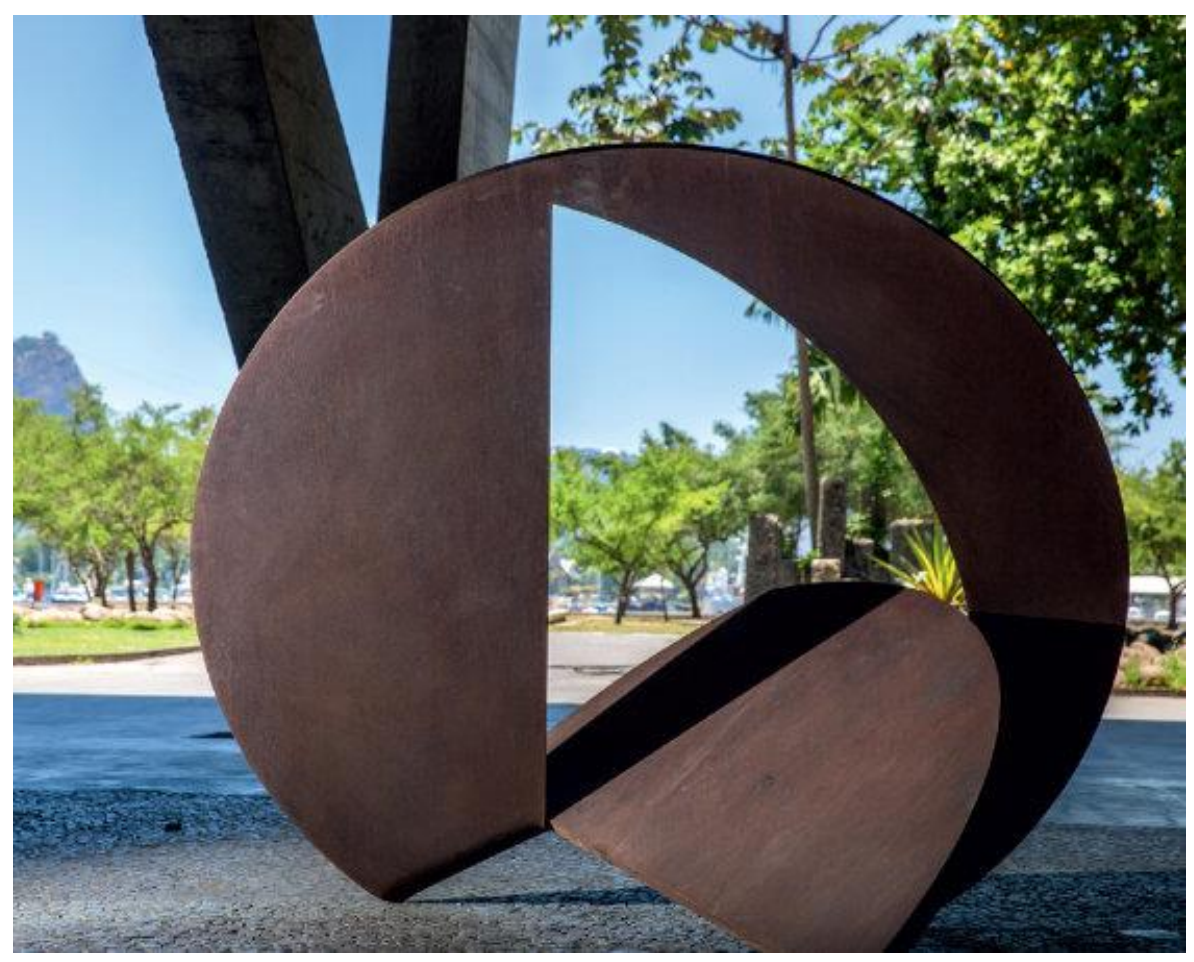

(Sem título, 1980 - Amilcar de Castro) [14]

\footnotetext{
${ }^{34}$ CHIARELLI, Tadeu. "Amilcar de Castro: corte e dobra". São Paulo: Cosac \& Naify, 2003.
} 
Não são gratuitas as suas escolhas. Dialoga com seus contemporâneos, assume os princípios de sua vanguarda, é consistente, mas não um dogmático. E talvez seja exatamente essa vazão ao que é singular, poético, específico da relação de um artista com seu universo que tenha gerado a ruptura entre as vanguardas de São Paulo e do Rio de Janeiro. A ortodoxia concreta jamais permitiria até mesmo o consistente Amilcar de Castro. Há quem possa atribuir as nuances geográficas a explicação das diferenças em relação à postura, o método e a liberdade nos trabalhos desses artistas, mas é inegável que ao abrir o precedente do diálogo em vez do dogma, da imaginação em vez da mera inventividade da forma, trabalhos com a tensão existencial de Amilcar e a abertura à alteridade pretendida pelos neoconcretos acentuariam o potencial poético e individual de cada artista. Não incomum, a dissolução da vanguarda neoconcreta se deu no aprofundamento existencial de determinadas pesquisas (como a passagem de Lygia Clark para a arteterapia) ou pela consistência invejável de trabalhos que ao se manterem fieis ao seu percurso poético, acabam por não se "adaptarem" ao imperativo da novidade presente nos discursos de vanguarda, e dignos, preferem se recolher na integridade de sua pesquisa individual. Foi o caso do escultor mineiro, que passou mais de quatro décadas variando pouquíssimo o material de trabalho, a pesquisa, e ainda assim a mantendo perene e pulsante como poucos trabalhos na história da arte. 


\section{Capítulo III - Amilcar singular}

O trabalho de Amilcar de Castro, seja ele escultórico, desenho sobre tela ou até mesmo seus poemas, é sempre um atestado de sua inabalável certeza de percurso, um trajeto coerente fundamentado em seu rigor metódico, em sua economia da sintaxe, nos elementos formais de seu léxico, os quais quase sempre partem de um plano e baseiam-se em duas regras - a dobra e o deslocamento. A enganosa simplicidade de seu método em contraste à tensão e densidade existencial de suas obras. A insistência do ferro. A resistência do ferro. A potência (poética e existencial) do ferro. Seu gesto adâmico que o acompanha desde as aulas com Guignard $^{35}$ e também marcaria suas esculturas futuras. A carreira de Amilcar são os desdobramentos da indagação que o acompanharia por todas as suas investidas: a conquista do espaço.

Neste capítulo, o que pretendemos é investigar, articular essa coerência que não deixava de se lançar à aventura ${ }^{36}$ e à experimentação, ou como dizia o próprio Amilcar: "O que mais me atrai é renovar dentro do vocabulário de formas que já está identificado com meu trabalho. É usar o mesmo para fazer algo diferente. "37 Quais são essas diferenças? E de que maneira elas podem ser compreendidas a ponto de formarem a coerência de seu trabalho?

Em sua primeira experimentação com a escultura efetivamente construtiva, datada de $1952^{38}$ (logo após seu contato com a obra e a teoria do suíço Max Bill): uma escultura na qual um retângulo de base bem extensa é dividido em três segmentos, cada um deles dobrado em triângulo. Dessa obra original é possível vislumbrar o procedimento e a relação com o espaço que o acompanharia em todas

\footnotetext{
${ }^{35}$ Sobre os anos de aprendizado com Guignard, Amilcar diria: "A borracha não conseguia apagar completamente o traço, que era uma incisão. Era preciso desenhar o melhor possível da primeira vez [...]. Esse método de desenho está na origem do meu processo de corte e dobra. Foi com lápis e papel que comecei a experimentar os sulcos e dobras que iria fazer no ferro." ${ }^{36}$ O crítico Paulo Sérgio Duarte, que assinou o prefácio de umas das mais completas retrospectivas dedicadas ao artista em 2005 na ocasião da Bienal do Mercosul descreve o trajeto Amilcar como uma "aventura da coerência". Ler em ALVES, José Francisco. Amilcar de Castro: Uma retrospectiva. Pref. Paulo Sérgio Duarte. Porto Alegre, Fundação Bienal de Artes Visuais do Mercosul, 2005.

${ }^{37}$ Idem Ibid.

${ }^{38} \mathrm{~A}$ escultura de corte e dobra selecionada, à época, para a 2 Bienal de São Paulo seria refeita em 2000.
} 
as outras, pelo desdobramento dos planos e pela insistência na operação de corte e dobra.

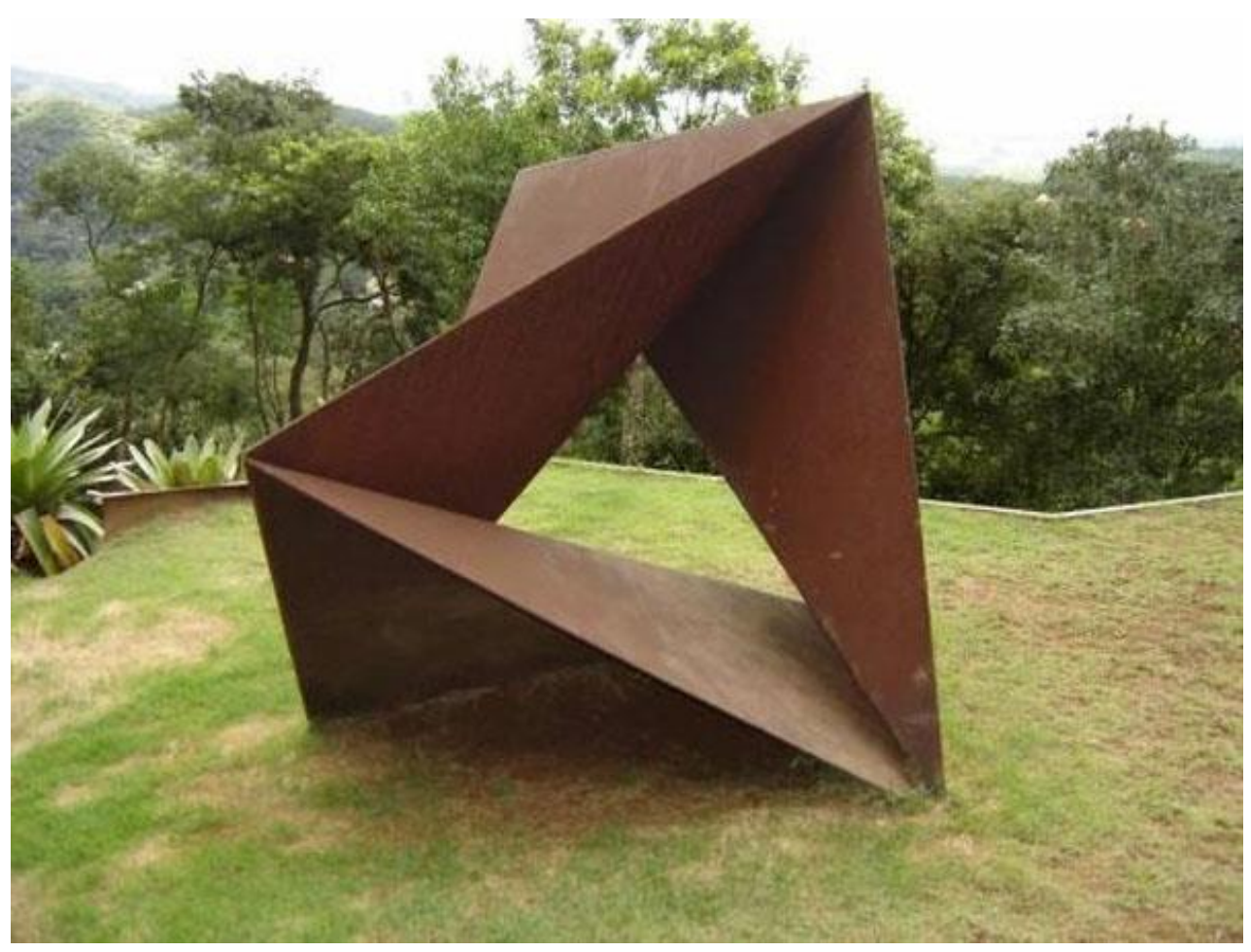

(Sem título, 1952/2000 - Amilcar de Castro) [15]

Feita em chapa fina, diferente da espessura que o marcaria ao longo da carreira e que só retomaria mais tarde em esculturas que ganhariam uma maior escala, e por assim dizer, experimentariam sua vocação pública; o material ainda não é seu aço cor-ten, mas o cobre; e seu procedimento, embora seja concebida a partir do corte, não é a dobra aqui que inaugura a tridimensionalidade da obra, mas uma operação de junção das chapas a partir da solda ainda.

Em peça da mesma década, ainda com o uso da solda, é possível perceber a evolução da dobra até a presença do corte. Na escultura datada de 1956 e que pertence ao MAM do Rio de Janeiro, Amilcar parte de uma chapa (já de aço) com forma inicial singular e a decompõe em três partes diferentes, posteriormente soldadas em ângulo entre si. 


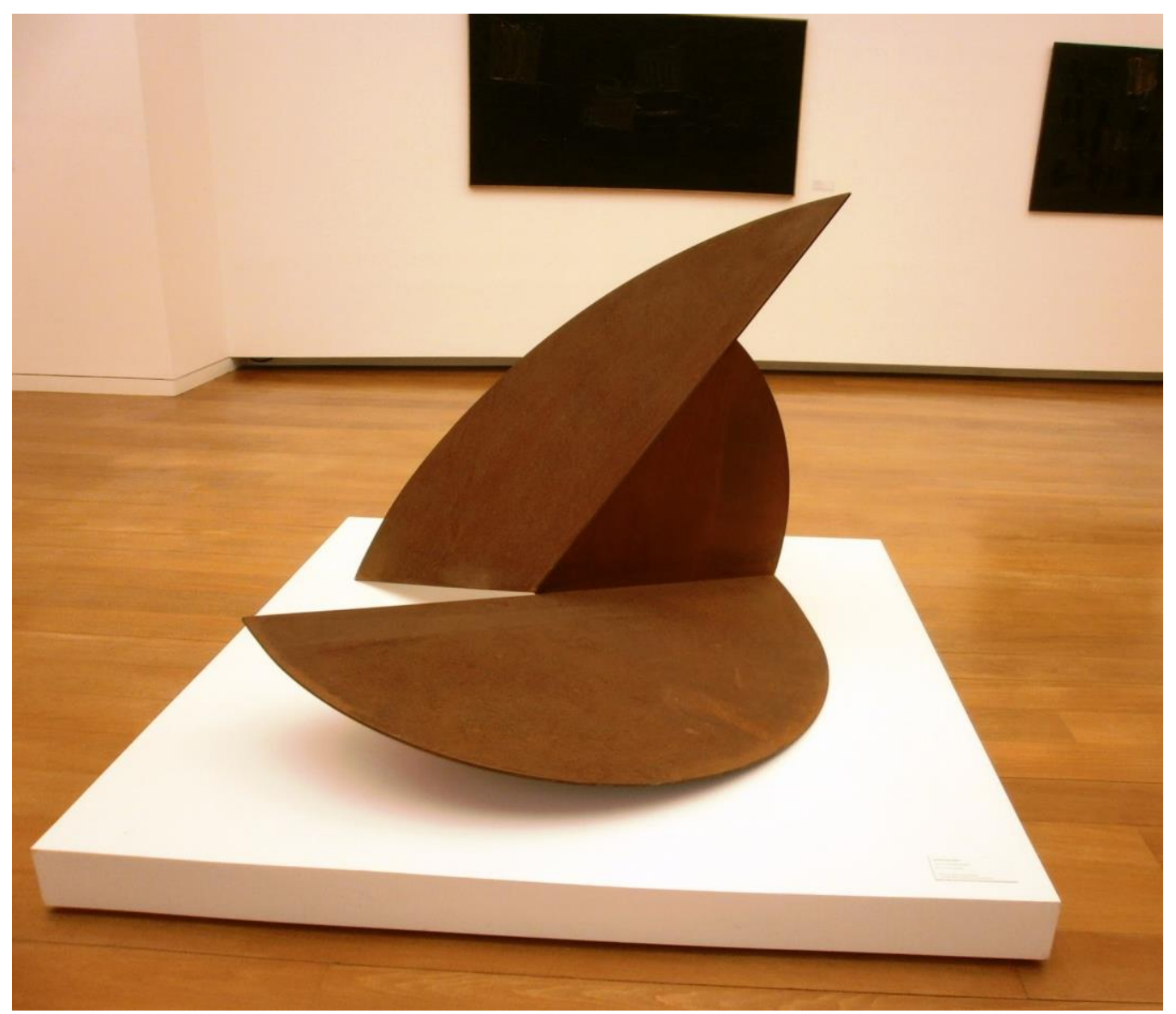

(Sem título, 1956 - Amilcar de Castro) [16]

Já é evidente nessa peça a articulação entre as chapas e a dobra, ainda feita pela solda, como a possibilidade da tridimensionalidade. Amilcar, talvez junto com Franz Weissmann e Sérgio Camargo, é uma das referências em relação à tridimensionalidade na escultura brasileira. Impossível pensar a inserção de um projeto construtivo brasileiro sem levar em alta estima os seus trabalhos e as suas experiências em relação ao plano. Suas esculturas, o que já fica evidente na peça mater, partem desse plano, e mesmo que conquistem a terceira dimensão, a essa condição original ainda a mantém como substrato estrutural ${ }^{39}$. Portanto, a operação de corte e dobra do plano sob formas geométricas elementares (sobretudo nas

\footnotetext{
${ }^{39}$ Sobre o procedimento, Hélio Oiticica analisaria em 1965: “Descobre, então, a relação fundamental entre o espaço e tempo na escultura, na sua fase em que de um plano desdobra a estrutura da obra em corte e torções sobre esse mesmo plano, isto é, não destrói o plano como substrato estrutural, mas o metamorfoseia numa pura representação espaço-temporal, nascendo daí toda a coerência e sentido da obra." Ver em ALVES, José Francisco. Amilcar de Castro: Uma retrospectiva. Pref. Paulo Sérgio Duarte. Porto Alegre, Fundação Bienal de Artes Visuais do Mercosul, 2005. Página 18.
} 
primeiras esculturas prevalecerá o circular e o quadrangular) é o que faz surgir a terceira dimensão. Suas chapas, soldadas, formando a tensão da dobra que sustenta a elevação do próprio plano é o que o fascinava. Era o tal mesmo pelo qual ele buscava sempre o diferente. Com o tempo, a continuidade do processo se deu a partir do descobrimento (técnico) da dobra sem o uso da solda, o que configurava ainda mais a unidade da peça e criava um lugar de tensão fundamental para o "voo de seus planos".

\begin{abstract}
Acompanhei, no começo dos anos 50, a busca que ele [Amilcar] realizava, suas perplexidades e tentativas diante da superfície inerme e muda que era sua única herança. Até que um dia veio-lhe a resposta: cortou um placa retangular no meio e moveu uma das partes para baixo e outra para cima; a placa bidimensional, com esse simples movimento, tornara-se tridimensional. Começa aí a escultura de Amilcar de Castro. Um corte e um gesto. A placa, invencivelmente calada e imóvel, enfim se anima e fala. Uma fala que se refere à sua própria origem e retorna incessantemente a ela, porque, na verdade, todas as obras que Amilcar produziu, desde aquele remoto momento, são variações daquela primeira obra. A placa muda de forma - quadrada, circular, paralelogrâmica -, muda de proporção, muda de espessura, mas como consequência do mesmo recurso expressivo: o corte e a dobra..$^{40}$
\end{abstract}

Foi exatamente nessa linha definitiva de trabalho que Amilcar apresentouse na 1 e 2 Exposição Neoconcreta (1959 e 1960). Na primeira exposição, a peça exposta é um exemplo do que nos referimos como a conquista da tridimensionalidade. Uma estrutura planar, de um aço de grossa espessura e quadrangular, com um único corte transversal, fendendo-o em dois campos; um deles, torcido para cima, faz surgir a conquistada dimensão. Enquanto em obras de anos anteriores, Amilcar fazia numerosos cortes, com suas partes torcidas para diferentes direções, a chapa parecia não só anunciar a conquista do novo plano, mas a experimentação dos limites que o material poderia suportar na operação. Nesta, exposta em 1959, a configuração é outra. O único corte favorece ao protagonismo da dobra, ao mesmo tempo que ela confere à obra leveza e tensão. Leveza ao modo que a erguer-se no espaço, sua chapa parece convocada ao voo. Tensão, na medida em que a dobra proporciona esse ponto de resistência da matéria bruta e a impõe,

\footnotetext{
${ }^{40}$ Ferreira Gullar, 2001. Ver em ALVES, José Francisco. Amilcar de Castro: Uma retrospectiva. Pref. Paulo Sérgio Duarte. Porto Alegre, Fundação Bienal de Artes Visuais do Mercosul, 2005. Página 18.
} 
quase a um gesto reflexivo, sobre o plano que a originou. Dessa forma, a condição da escultura traz sempre a memória do plano primordial que a gerou ${ }^{41}$.

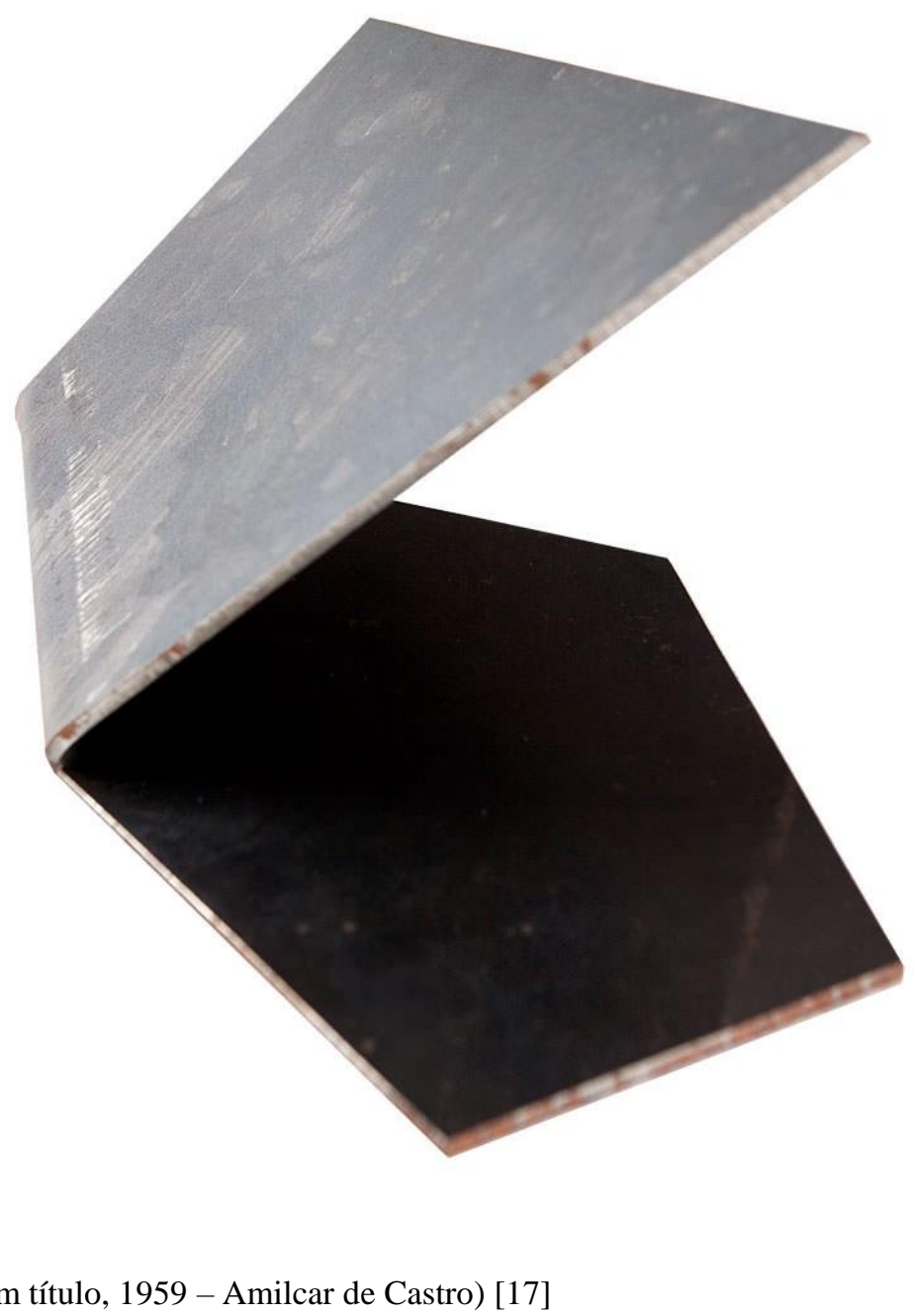

A dobra, portanto, funciona como signo distintivo de sua original lógica construtiva. Em uma escultura que parte de uma drástica redução abstrata e pretende cifrar-se a partir da estrita articulação de seus planos geométricos, a dobra, ponto

${ }^{41}$ Sônia Salzstein, 1988. Ver em ALVES, José Francisco. Amilcar de Castro: Uma retrospectiva. Pref. Paulo Sérgio Duarte. Porto Alegre, Fundação Bienal de Artes Visuais do Mercosul, 2005. Página 19. 
de tensão, dobrando a chapa sobre si mesma, garante à obra interioridade, e de certa forma, reflexividade ${ }^{42}$.

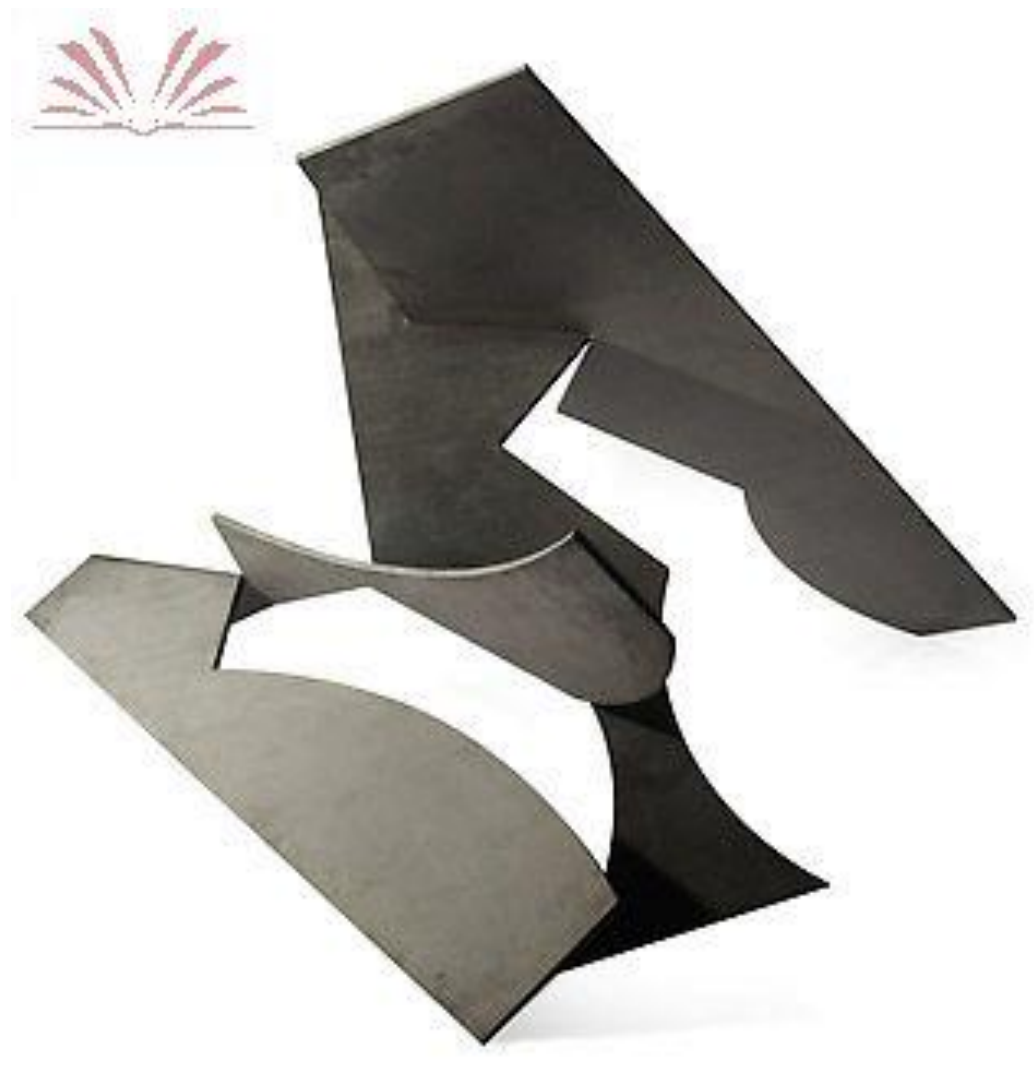

(Sem título, 1959 - Amilcar de Castro) [18]

Se por um lado, é esse procedimento que garante ao plano a sua possibilidade de emersão e experimentar-se no espaço, por outro, o gesto de dobrarse sobre si própria garante esse tributo à origem planar. Em algumas peças, sobretudo nas que os cortes e dobras são numerosos, a vitalidade de seu procedimento se traduz em esculturas que parecem que eternamente estarão se desdobrando no espaço em suas articulações geométricas e fluidas. Há também uma considerável diferença do momento em que a dobra é concebida a partir da solda e quando esse procedimento passa a ser feito com prensa quente.

\footnotetext{
42 Ver em BRITO, Ronaldo. Neoconcretismo: vértice e ruptura do projeto construtivo brasileiro. São Paulo: Cosac Naify, 1999
} 
Quando ainda fazia uso da solda para a junção das chapas de ferro, por mais que o ímpeto construtivo sobre o plano estivesse já presente, e fosse ele próprio a justificativa da solda, é a partir da descoberta da dobra conseguida a partir da prensa que dá ao seu trabalho a densidade que sua poética exigia. Em temperatura regulada, a prensa sobre a chapa garante sua torção e o ponto de tensão nevrálgico entre o plano e a terceira dimensão. A dobra ainda garante a unidade da chapa e desafia a resistência da matéria. Um ponto de tensão conceitual e técnica - o gesto é único, incorrigível. Bem ao modo de Amilcar.

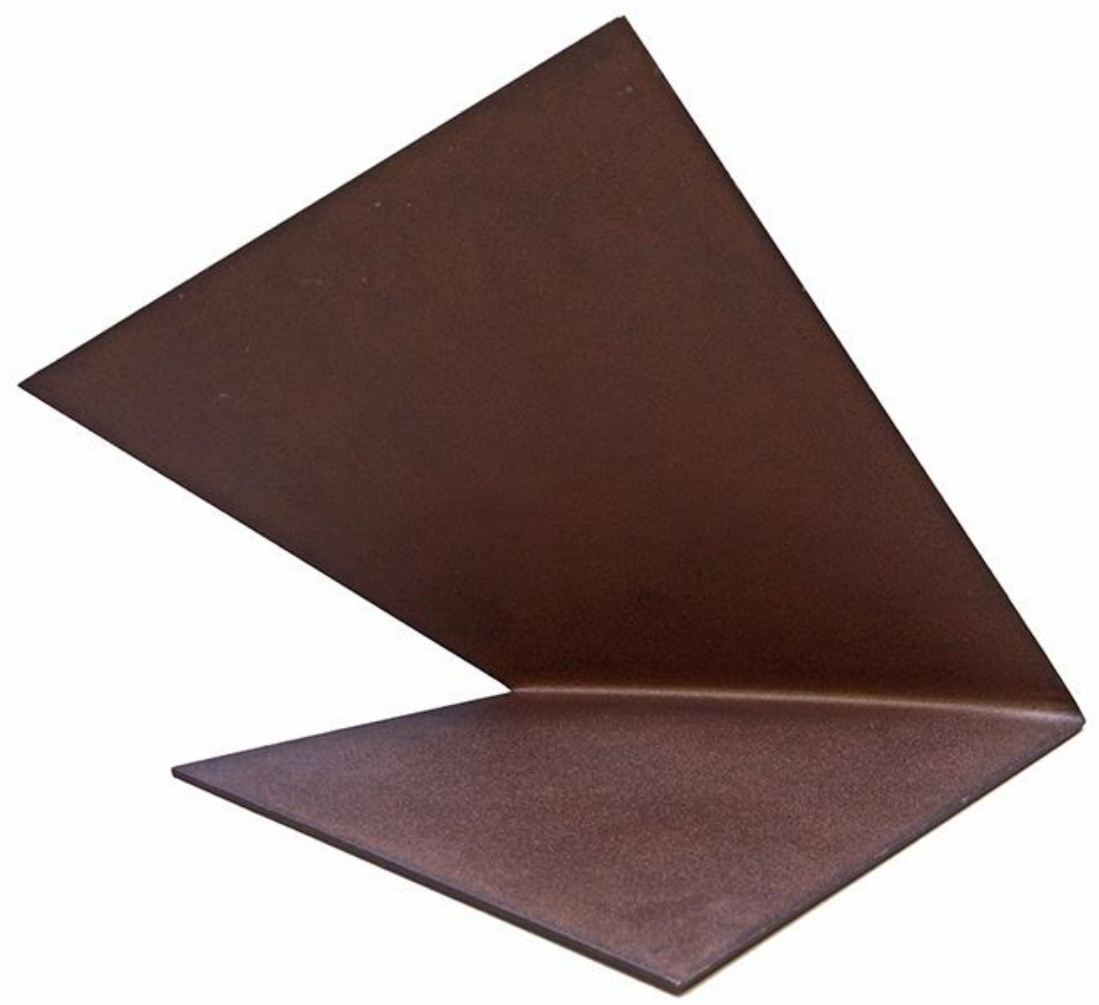

(Sem título, 1959 - Amilcar de Castro) [19]

Tratando-se de um material de tamanha resistência, a dobra funciona como uma regra de incisão que demarca os planos ao mesmo tempo que os articula em uma unidade, efeito que a solda não conseguiu. Um procedimento de risco, que em sua irreversibilidade que nos repõe diante da possibilidade de gestos e práticas que produzem desdobramentos 
incontornáveis. Ferreira Gullar definia o método de trabalho de Amilcar como no cerne da aventura geométrica, técnica, processual. Embora partisse muitas vezes do desenho sobre o papel para ali encontrar a escultura, não é possível definir esses desenhos como preparatórios, da mesma maneira que não era uma experimentação direta com o material. Amilcar garantia-se em seu método sem abandonar o acaso. Ou como definia Gullar: "como quem esperasse um milagre, já que o acerto deve ser instântaneo", que seria o aparecimento, a conquista, dessa nova dimensão. Que, mais cético que o poeta, Amilcar tentaria responder: "é pleno mistério".

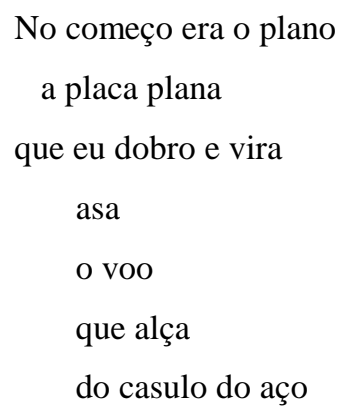

A obra
eu a começo
do começo
de zero
(se não erro)
pra que a placa
$\quad$ que dobra
$\quad$ e vira asa
nunca esqueça
seu começo
e a ele volte sem erro
e assim viva
esta nova idade do ferro

(Mínimo voo, 2010 - Ferreira Gullar) ${ }^{43}$

43 Poema dedicado a Amilcar de Castro em GULLAR, Ferreira. Em alguma parte alguma. Editora José Olympio. Rio de Janeiro, 2010. Página 109 
É esse mínimo voo, conquistado pela dobra, que expande as possibilidades de relação com o espaço e no mesmo gesto, em que a chapa que emerge, também confere unidade ao plano que a originou que percebemos a grandeza de um gesto simples, decidido e sem margens para o erro. Ao erguer a chapa, uma nova dimensão. A dobra, quase como asas de ferro, como sustentação de sua forma aberta, de sua experiência no espaço. Suas esculturas como os versos de um outro mineiro, Guimarães Rosa: "passarinho que se debruça - o voo está pronto"

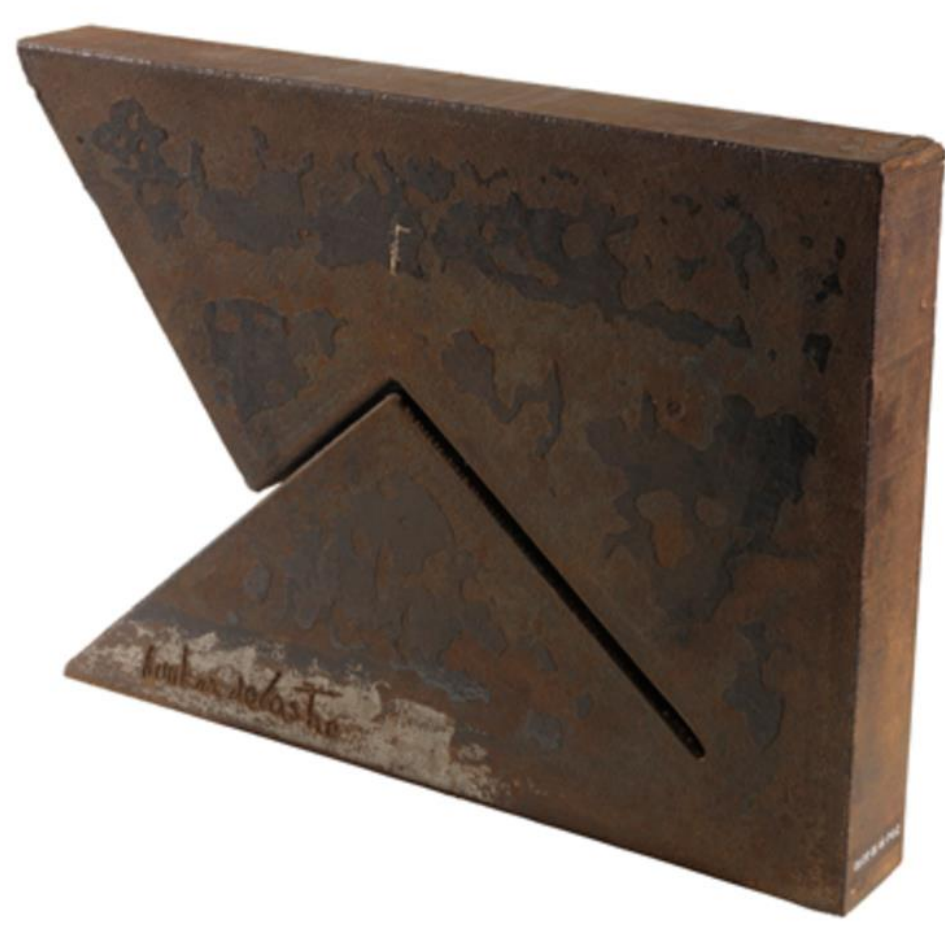

(Sem título, 1980 - Amilcar de Castro) [20]

Posteriormente às experiências com a dobra, Amilcar passou a adotar o corte e dobra, mais uma vez reafirmando em cada peça inteiramente nova a atualização de um repertório fiel aos seus princípios. Trajeto retilíneo e expansivo em uma sintaxe simples e densa ao mesmo tempo.

${ }^{44}$ ROSA, João Guimarães. Grande Sertão: veredas. Editora Nova Fronteira. Rio de Janeiro, 2006. 
Aluno de Guignard, a quem tinha grande admiração como pintor e mestre, Amilcar nunca se reconheceu como um pintor, até mesmo em suas experiências sobre a tela preferia definir como "desenho sobre tela", e não pintura. Era esse o seu interesse: preto, branco, linha.

\begin{abstract}
O desenho sempre foi uma maneira de pensar do artista plástico. O que faço é reorganizar uma área usando cor, assim como eu faço com a escultura. $\mathrm{O}$ mundo inteiro diz que óleo sobre tela é pintura. Mas isso é uma maneira boba de falar. Se você olha o mundo e traduz o mundo em linhas, você é um desenhista e não um pintor. Se olha para o mundo e traduz o mundo em cor, você é pintor. O Guignard é pintor sem dúvida. Matisse é pintor. Eu não sou pintor. A escultura é estrutura, questão construtiva. Tem parentesco, no meu modo de pensar, com a arquitetura e está mais perto da construção, da organização espacial. ${ }^{45}$
\end{abstract}

A forma como o corte é pensado dentro de seu trabalho é como linha, enquanto desenho. E desenho enquanto construção de espaço. Não raro, Amilcar definia a si próprio como um gráfico, alguém cuja preocupação inicial era entre o preto, o branco e a linha. Conquistar, construir e experimentar o espaço a partir desses princípios. De fato, até mesmo em seu trabalho de diagramador e principalmente em seus desenhos, e sem exagero, poderíamos inclusive citar seus poemas, é visível a preocupação espacial, a preocupação com a forma, a escultura enquanto acontecimento no espaço, e parte fundamental de sua poética é o desenho como base.

Em esculturas dá década de 1980, Amilcar que tinha acabado de retornar de uma temporada nos Estados Unidos em que chegou a trabalhar com o aço inoxidável (material que não se adaptou bem), volta às chapas de ferro, e devido a um novo momento industrial do país, consegue uma variação maior em relação a espessura, propiciando novas experimentações. Nesse sentido, as esculturas passam a ser concebidas apenas a partir do corte, abdicando da dobra e consequentemente da criação do volume virtual. Nesses blocos (em geral de pequeno tamanho e forma retangular ou quadrada) o corte vale por si mesmo e não como um meio para possibilitar a dobra: ele é feito para permitir a penetração do espaço no bloco compacto, ou, em alguns casos, permitir a inserção de um bloco no outro. São seus sólidos geométricos.

\footnotetext{
${ }^{45}$ Ver em ALVES, José Francisco. Amilcar de Castro: Uma retrospectiva. Pref. Paulo Sérgio Duarte. Porto Alegre, Fundação Bienal de Artes Visuais do Mercosul, 2005. Página 86.
} 


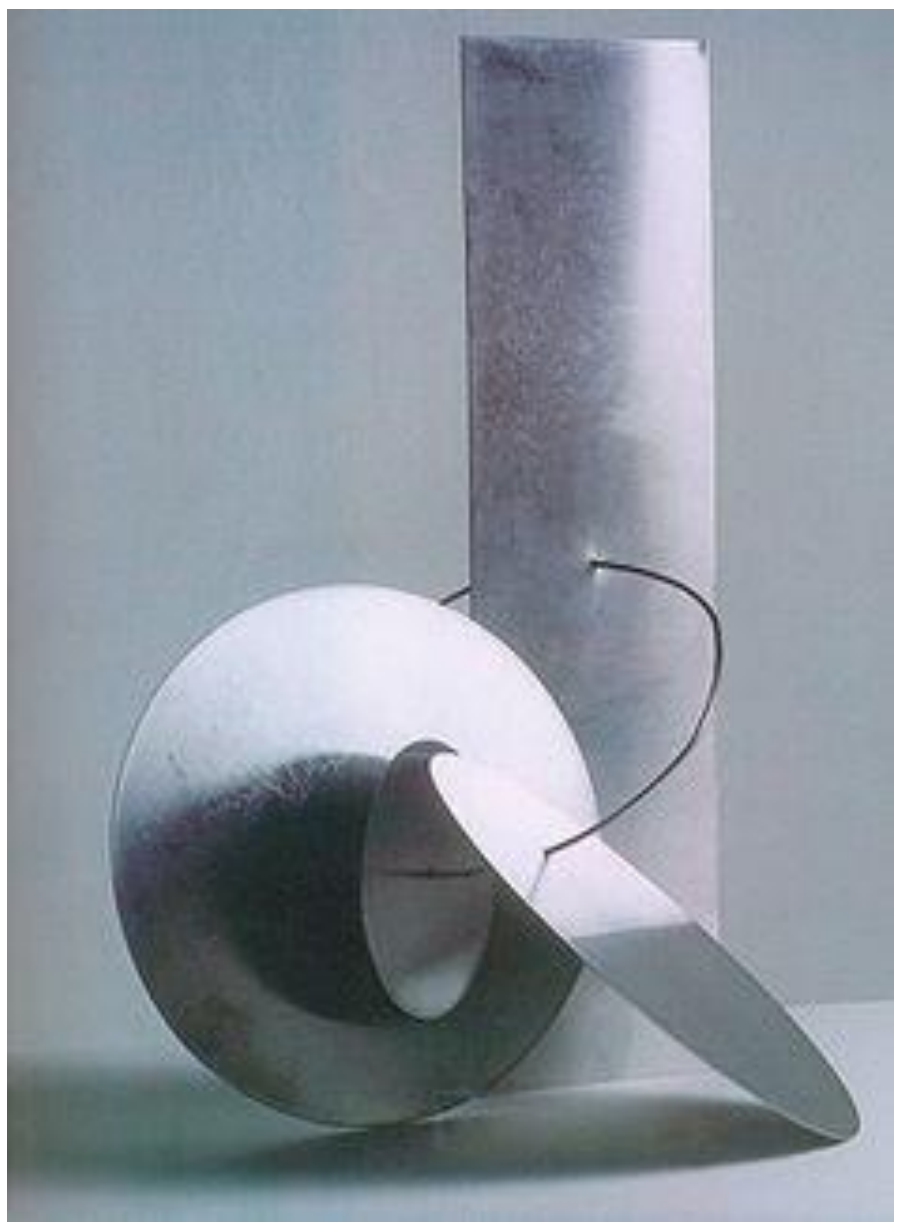

(Sem título, 1972 - Amilcar de Castro) [21]

Seus cortes à medida que parecem ferir o bloco de aço, permitem a inserção do vazio na escultura, e nesse sentido, a massa do bloco, sua demasiada espessura é fundamental para o efeito desejado. A densidade permanece na matéria, mas agora em vez da dobra como um elemento tensional e de alcance da terceira dimensão, agora o corte é quem mobiliza o vazio, torna ele aparente, o repõe em sua experiência topológica e o insere como parte integrante e significativa na escultura.

Com as linhas incandescentes do maçarico sobre o bloco, abre-se uma fenda no sólido, e mais uma vez está aí o gesto incisivo, único, sem possibilidades de retoque ou retorno. A incisão divide o bloco de fora a fora, separando-o em dois corpos distintos. $\mathrm{O}$ corte parte de um dos vértices, vai até o centro do quadrilátero e baixa em perpendicular até o meio do lado da "base" do sólido. Amilcar alcança essas inúmeras possibilidades a partir do método que define como "um jogo de 
várias possibilidades de composição" ${ }^{46}$ Em alguns casos, o método era outro: as esculturas eram de fato partidas e suas partes articuladas entre si, trazendo à tona um outro método - o corte e deslocamento.

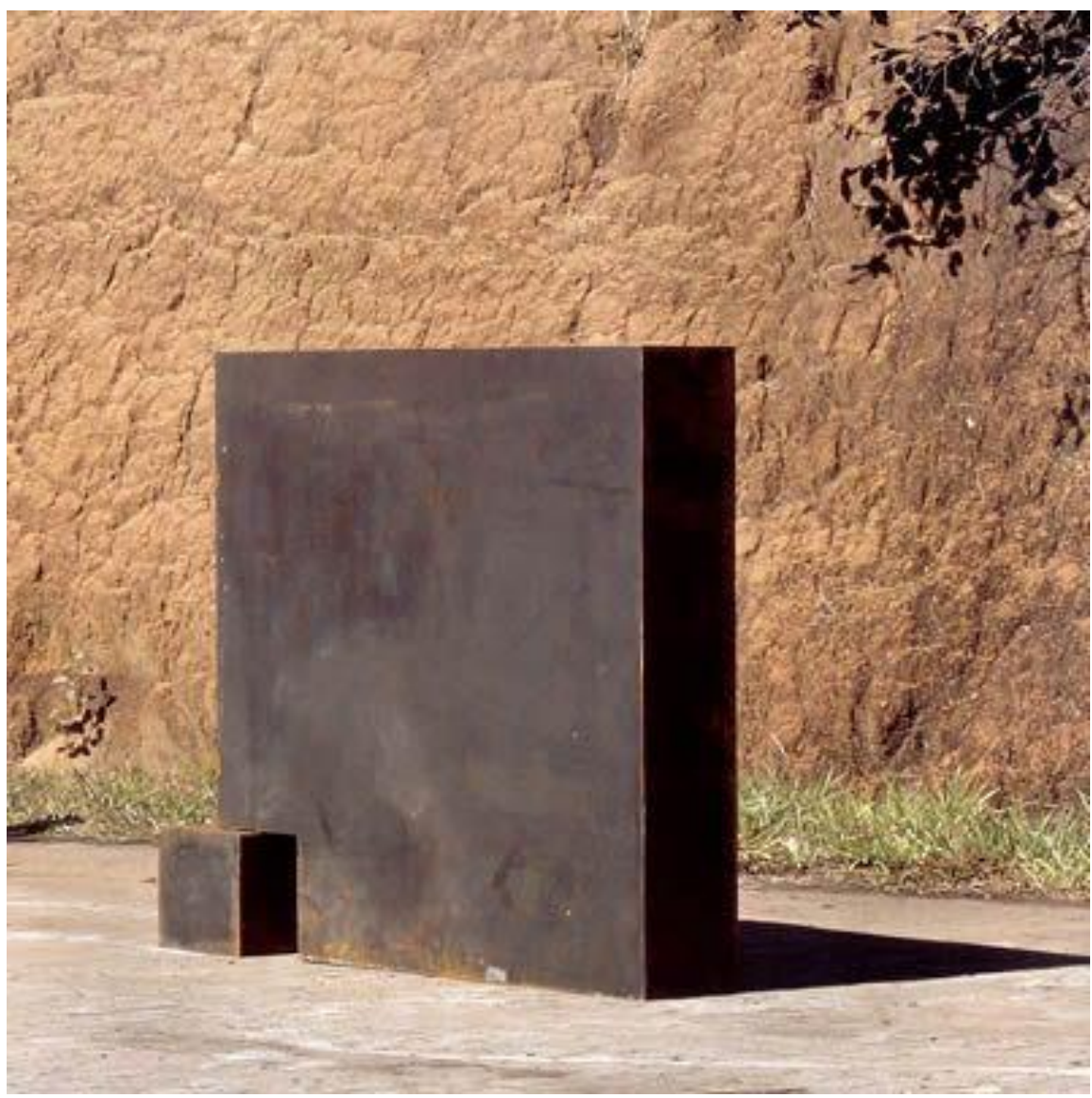

(Sem título, 1980 - Amilcar de Castro) [22]

Nos sólidos em que há além do corte, o deslocamento de alguma das peças, mantém-se a relação com o vazio, o incorporando à escultura, mas com a diferença de que o deslocamento permite a ampliação da área de atuação da peça:

Sintomaticamente, a manipulação eventual dos elementos soltos, sua disponibilidade lúdica, vinha contrabalançada pelo seu próprio peso e, ainda, pela "demora" que a assimilação visual de cada nova situação demandava ${ }^{47}$

Um bloco quadrangular de grande espessura que em uma de suas arestas apoia-se em outro bloco, também quadrangular, de menor espessura. Entre os blocos, o

\footnotetext{
${ }^{46}$ Ver em ALVES, José Francisco. Amilcar de Castro: Uma retrospectiva. Pref. Paulo Sérgio Duarte. Porto Alegre, Fundação Bienal de Artes Visuais do Mercosul, 2005. Página 21.

${ }^{47}$ BRITO, Ronaldo. Neoconcretismo: vértice e ruptura do projeto construtivo brasileiro. São Paulo: Cosac Naify, 1999
} 
deslocamento insere o vazio, virtualmente também compreendido em forma quadrangular. A geometria como fundamento, mas a serviço de sua sensibilidade e imaginação.

Em momento anterior, comparamos o trabalho de Amilcar ao de Weissmann em relação a forma cada um desdobra sua escultura no espaço. Se por um lado Weissmann tem um lirismo de certa forma mais leve, fluído, como se suas chapas fossem flores se abrindo, fitas que se expandem e parecem buscar novas experimentações no espaço. Já Amilcar tem uma densidade existencial maior, não pintava suas chapas, deixava o tempo agir sobre elas e conquistou o vazio enquanto parte integrante e significativa da escultura. Em seu trabalho sobressai a interioridade, a reflexividade da obra e seu peso existencial e material, como já discutimos em relação à dobra.

No entanto, em recente artigo ${ }^{48}$, o crítico Sérgio Bruno Martins traz alguns pontos fundamentais para essa afirmação da individualidade artística de Amilcar em detrimento de um alinhamento total aos imperativos de vanguarda, entre eles, e que aqui mais nos interessa, a maneira como a obra de Amilcar pode ser compreendida como um ponto cego dentro da Teoria do não-objeto (cara à vanguarda neoconcreta) exatamente pela forma como o artista lida com o espaço.

Se partirmos do mesmo contraponto do artigo, a comparação entre as obras de Amilcar de Castro e Luiz Sacilotto, podemos ver essa diferença de mobilização do vazio. Paulista de 1924, pouco mais novo que o mineiro Amilcar, Sacilotto filiou-se a vanguarda concretista e participando da Primeira Exposição de Arte Concreta, em São Paulo e Rio de Janeiro, em 1956 e 1957. Marcado por uma obra inventiva sob o léxico geométrico concretista, Sacilotto em 1959 expõe "Concreção 5942”, parte de uma série de experimentações que partem de um plano quadrado em uma elaborada série de operações de corte, dobra e solda sobre o metal multiplicando sua forma original, quase como uma homenagem ao quadrado. Ao erguer suas faixas de metal, forma intervalos regulares e equivalentes em largura às

\footnotetext{
48 MARTINS, Sergio Bruno. Entre a fenomenologia e o historicismo: Amilcar de Castro enquanto ponto cego da teoria do não-objeto. 2010. Disponível no site http://www.academia.edu/24061256/Entre_a_fenomenologia_e_o_historicismo_Amilcar_de_Ca stro_enquanto_ponto_cego_da_teoria_do_n\%C3\%A3o-objeto
} 
próprias faixas, a uma maneira que a faixa (negra) contrasta perfeitamente com o intervalo (vazio, branco), incorporando graficamente o vazio à escultura ${ }^{49}$.

Um trabalho perfeitamente inserido no ideário concretista, tributário de seu estrito rigor estético ao mesmo tempo que atualiza essa inventividade sobre o repertório visual da vanguarda. Princípios estéticos como a repetição articulada de uma mesma figura geométrica e a relação de emersão do plano presentes na obra de Sacilotto muito se assemelham a uma experiência empreendida por Joseph Albers quando ainda dava aula na famosa Escola de Bauhaus, em papel e interessado no desdobramento de uma mesma figura geométrica (círculo, na ocasião) ainda que lhe fosse possível conquistar a terceira dimensão aparecem em trabalho de 1928 que muito provavelmente Sacilotto pagou tributo, afinal é base teórico concretista a escola alemã e suas aspirações de vanguarda.

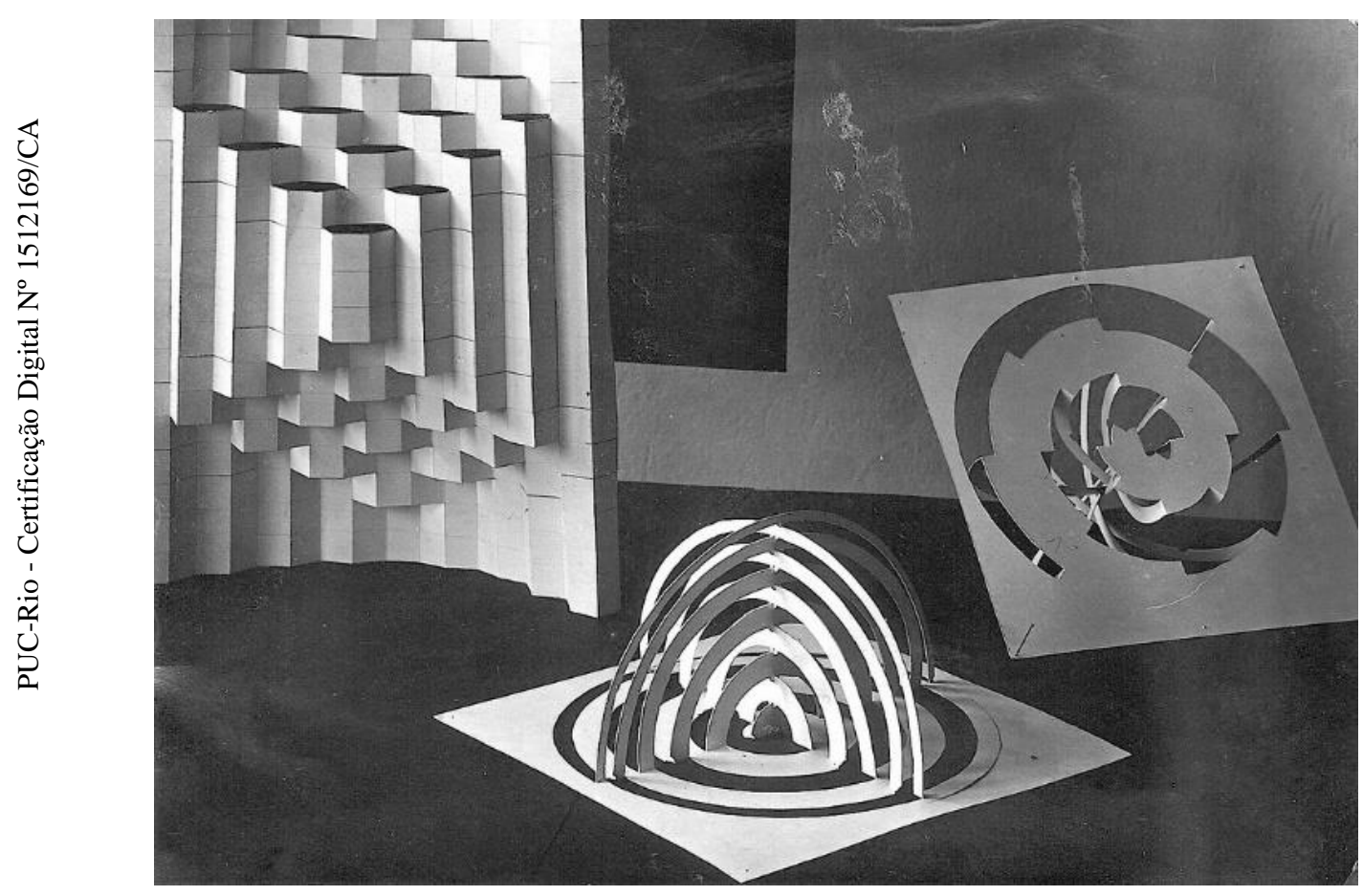

(Sem título, 1928 - Joseph Albers) [23]

\footnotetext{
${ }^{49}$ Nesse sentido, resume Sérgio Bruno Martins: “Com isso, a oposição entre matéria opaca e espaço vazio é superada pela cooperação imediata entre faixa e intervalo na formação das gestalts íntegras." Id. Ibidem.
} 


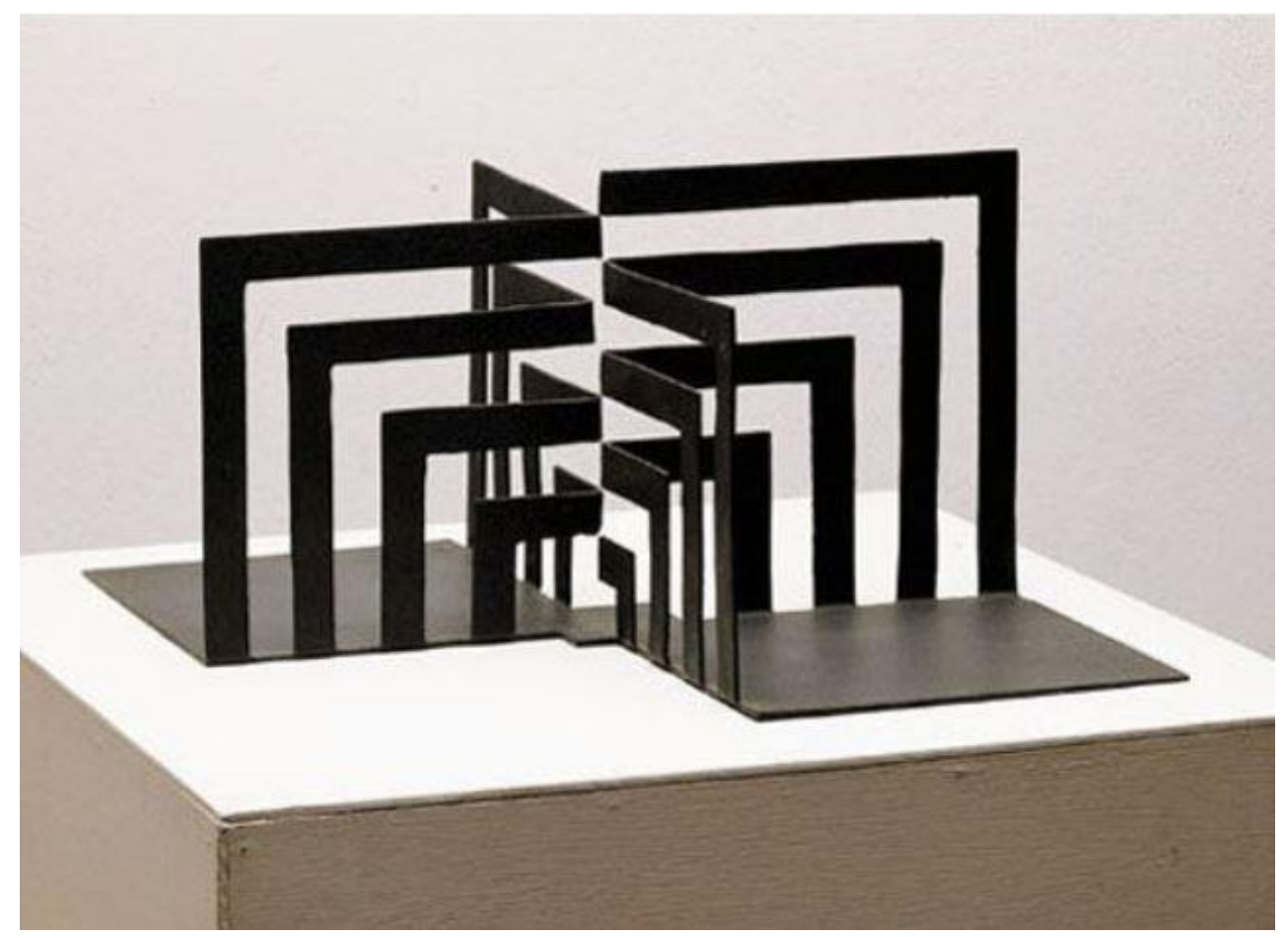

(Concreção, 1959 - Luiz Sacilotto) [24]

A obra é uma homenagem à geometria: a partir de uma única superfície cria vários planos sem nunca perder a referência da forma original, definitivamente o quadrado. $\mathrm{O}$ trabalho, nesse sentido, depende tanto de sua capacidade de multiplicar a forma que lhe serve de origem quanto da manutenção dessa referência primeira ${ }^{50}$. O princípio generativo nunca se perde e esse era um de seus objetivos, da vanguarda como um todo, que acabava por ao mesmo tempo que enfatiza essa preponderância do objeto, no sentido de que decodifica-lo passaria por reconstituir a série de determinações em sua raiz, também joga a percepção do espectador para um campo muito mais racional, em que parte fundamental da fruição é o entendimento desse desdobramento inventivo da geometria planar e da potência espacial do quadrado; completamente diferente da carga existencial e subjetiva que as obras de Amilcar impunham. É impossível reconstituir seu processo, estamos no limbo de uma fruição que se alimenta da aporia entre a aparente simplicidade do objeto e profunda tensão existencial de seu acontecimento.

\footnotetext{
${ }^{50}$ Ver em BELLUZZO, Ana Maria. Ruptura e Arte Concreta. In: AMARAL, Aracy (coord.). Arte construtiva no Brasil: Coleção Adolpho Leirner. São Paulo: DBA, 1998
} 


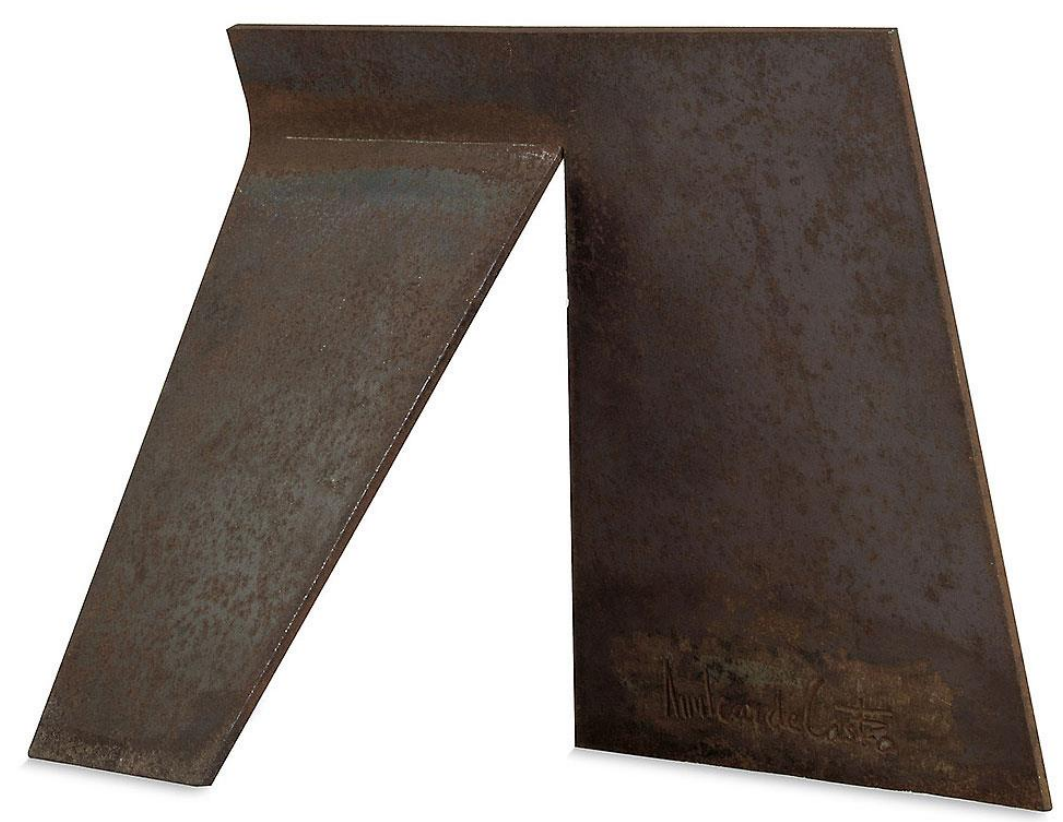

(Sem título, 1966 - Amilcar de Castro) [25]

A maneira como o vazio é mobilizado na obra de Amilcar é fundamentalmente diferente ao de Sacilotto. Embora o próprio artista muitas vezes tenha se colocado acima de tudo como um gráfico ${ }^{51}$, Amilcar tinha uma outra relação com o espaço, o que o colocava em distância até mesmo de seus companheiros de vanguarda.

Em suas esculturas o vazio contribui como algo significativo em si. Em Sacilotto, as lacunas são equivalentes aos segmentos materiais da escultura, pertencem ao mesmo registro planar. Amilcar com suas dobras conquista a terceira dimensão e constrói um novo espaço a partir dessa experimentação geométrica (embora de uma geometria, em certo sentido, muito mais sensível que a do paulista) e topológica, inseparavelmente.

Se pensarmos, por exemplo, uma de suas esculturas de 1966: uma chapa de ferro com um corte levemente em diagonal que separa o material e com a dobra desloca uma das placas criando um vão, conquistando a terceira dimensão e

\footnotetext{
51 Depoimento presente no documentário do projeto “Circuito Atelier número 5". Direção de Nélio Costa.
} 
equilibrando a peça na extremidade dessas chapas. Uma peça como essa é impossível pensar em sua medição diretamente em relação ao plano, mas exatamente em relação a sua ausência.

Como se fosse uma função estruturada fracassada, como resume Sérgio Bruno Martins, o plano aparece na escultura de Amilcar como uma reminiscência: é perfeitamente possível compreender sua experimentação como algo que parte do plano, ao mesmo tempo que esse plano nunca é uma presença efetiva, mas o seu desdobramento.

Tanto real quanto virtualmente, o plano reluta em ganhar forma; ele atua, por assim dizer, como uma referência negativa, como uma espécie de fundo (e fundamento) ausente, mas que ainda assim é o que confere consistência formal e fenomenológica à obra. ${ }^{52}$

Talvez exatamente por constituir-se como uma referência negativa e por isso não se deixar fixar que sua obra, apesar da famosa coerência e da enganosa impressão de que seus trabalhos se repetem é atualizada a todo instante em seu repertório poético e visual. A coerência se alimenta nas inúmeras possibilidades dessa incompletude. E é exatamente por essa impossibilidade de presentificação do plano prometido que seu trabalho se distancia da teoria proposta por Ferreira Gullar: suas esculturas adquirem consistência na medida em que se encontram ancoradas negativamente por uma planeza inatingível. A radicalidade é tal que a escultura de Amilcar chega ao ponto de assumir o plano geométrico, base estética do projeto construtivo, como um objeto perdido ${ }^{53}$ :

\begin{abstract}
Objetos percebidos, são, então, "percepções fugazes" que parecem adquirir "o peso da objetividade apenas quando são lastreadas ou ancoradas pelo objeto real excluído". A negatividade articulada pelas esculturas de Amilcar está, desse ponto de vista, em desacordo com o não-objeto: são esculturas que adquirem consistência na medida em que se encontram ancoradas negativamente por uma planeza inatingível ${ }^{54}$
\end{abstract}

\footnotetext{
${ }^{52}$ MARTINS, Sergio Bruno. Entre a fenomenologia e o historicismo: Amilcar de Castro enquanto ponto cego da teoria do não-objeto. 2010. Disponível no site http://www.academia.edu/24061256/Entre_a_fenomenologia_e_o_historicismo_Amilcar_de_Ca stro_enquanto_ponto_cego_da_teoria_do_n\%C3\%A3o-objeto

${ }^{53}$ No artigo, Sérgio Bruno Martins diferencia a noção de percepção proposta por Merleau-Ponty (base teórica de Gullar para pensar sua Teoria) da psicanálise (Copjec, 1994), que trabalha com a questão do objeto reconhecido enquanto um objeto reencontrado, um objeto desde sempre perdido. Id. Ibidem.

${ }^{54}$ Id. Ibidem.
} 
A obra de Amilcar, nesse sentido, não se encaixa à Teoria proposta por Gullar e mais do que isso: abre um precedente em seu historicismo. Se pensarmos a construção da teoria (não à toa começa pela "Morte da pintura") como um caminho narrativo também de legitimação da própria vanguarda, não só em seu sentido estritamente técnico, mas na formulação de sua própria genealogia e na eleição (e construção) das heranças que o neoconcretismo tinha por objetivo seguir adiante.

Ainda editor do Suplemento Dominical do antigo Jornal do Brasil em 1959, Gullar escreve uma série de artigos que mais tarde iria compor sua coletânea de ensaios "Etapas da Arte Contemporânea: do cubismo ao neoconcretismo" 55 em que é evidente a formação de seu corpo teórico, o encontro com Merleau-Ponty ${ }^{56}$, mas sobretudo, o ponto originário de sua teoria: a passagem da segunda para a terceira dimensão, consequentemente, a passagem de uma primazia pictórica para a conquista do espaço. E nesse aspecto, há de fato essa característica topológica na obra de Amilcar. Não há base para suas esculturas, estão dispostas fenomenologicamente no mundo e a ausência desse espaço metafórico de manifestação da arte amplia essa disposição, essa experimentação no espaço e na subjetividade.

O espaço é conquistado, mas na mesma circunstância em que a dobra traduz essa reflexividade da obra, esse tributo ao plano originário não é tão evidente. Como já analisamos, o plano "aparece" como uma referência negativa, a obra se sustenta, e talvez por isso a dificuldade de compreender sua consistência como uma preguiçosa repetição, porque é exatamente sobre a repetição desse encontro fracassado que está o ineditismo de cada uma de suas esculturas. Muitas vezes o mesmo método, o mesmo material, mas não cessa a avidez por essa incompletude fundamental de suas esculturas. E é sobre essa mesma incompletude e impossibilidade de presentificação do plano originário senão como a mobilização

\footnotetext{
55 GULLAR, Ferreira. Etapas da Arte Contemporânea: do cubismo ao neoconcretismo. Editora Nobel. São Paulo, 1985.

$56 \mathrm{O}$ artigo de Sérgio Bruno Martins analisa o desdobramento da Teoria de Gullar também como uma maneira ao mesmo não declarada de reconhecimento da Gestalt, tão defendida por seu mestre Mário Pedrosa, como também uma possibilidade de afirmação (e também autoridade) frente $o$ antigo mestre. Ver em MARTINS, Sergio Bruno. Entre a fenomenologia e o historicismo: Amilcar de Castro enquanto ponto cego da teoria do não-objeto. 2010. Disponível no site http://www.academia.edu/24061256/Entre_a_fenomenologia_e_o_historicismo_Amilcar_de_Ca stro_enquanto_ponto_cego_da_teoria_do_n\%C3\%A3o-objeto
} 
de sua ausência que a Teoria de Gullar, precípua ao entendimento da vanguarda neoconcreta, não consegue dar conta. Como se ao tentar mirar esse espelho retrovisor a uma ampla visão (historicista e fenomenológica) daquele momento, apesar de muitas vezes monumentais, a obra de Amilcar ser esse escotoma - ou essa singularidade obstinada e quase sempre também por isso, inclassificável.

\section{1 - Outros suportes: desenho sobre tela e poema}

Amilcar ao se referir aos seus trabalhos sobre a tela, jamais se colocava como um pintor, ou até mesmo que aquela experiência fosse uma pintura, ainda que sobre a tela convergisse pincel e tinta. $\mathrm{O}$ artista definia definia-os desenho sobre tela, ainda que sobre ela não convergisse lápis, giz ou nanquim.

Atento ao desenho desde as aulas de Guignard, Amilcar retoma essa experiência após o retorno de uma temporada nos Estados Unidos, em 1972. Sendo uma produção muito menos custosa do que suas esculturas ${ }^{57}$ e de fácil exposição, o papel reaparece como suporte de sua primeira exposição individual após o retorno, em 1978 em São Paulo. Sobre o nanquim sobre papel, a crítica Aracy Amaral disse à época:

\footnotetext{
O gestual governa a caligrafia construtiva para anotar a escultura futura [...] não deixa de ser sintomático da sua presença o deixar claro que esses desenhos podem ser apresentados de qualquer ângulo, sua leitura não pressupondo "alto e baixo", "esquerda e direita". Aqui, o desenho já oferece a abertura da peça tridimensional $[\ldots]^{58}$
}

\footnotetext{
${ }^{57}$ No período em que vive nos Estados Unidos, Amilcar tem dificuldades para encontrar seu aço cor-ten e durante esse período passa também a trabalhar com o aço inoxidável, material que teria alguma resistência em se adaptar.

${ }^{58}$ ALVES, José Francisco. Amilcar de Castro: Uma retrospectiva. Pref. Paulo Sérgio Duarte. Porto Alegre, Fundação Bienal de Artes Visuais do Mercosul, 2005. Página 85.
} 


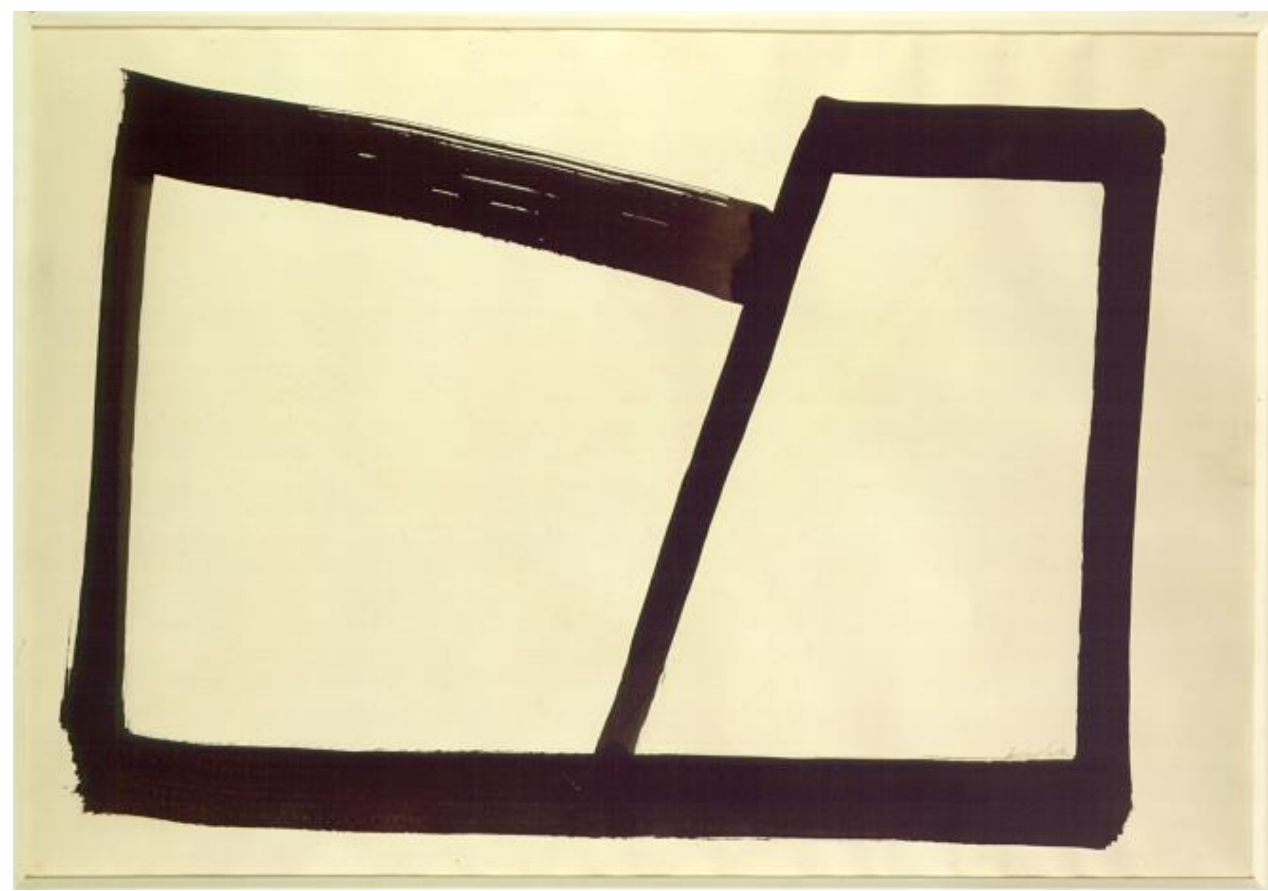

(Sem título, 1977 - Amilcar de Castro) [26]

Seus desenhos atendem à demanda desse ímpeto gráfico que tanto permeia a obra de Amilcar e o levava a se autodefinir como um desenhista, pois pensava o mundo a partir de linhas, e não da cor, como seu antigo Mestre Guignard ou um Matisse. E, de fato, em seus desenhos a preocupação precípua é com a linha, o branco e o preto. Se eventualmente surge uma outra cor, agrega-se a essa sintaxe construtiva que mesmo sobre o papel ou a tela ainda obstina o espaço. 


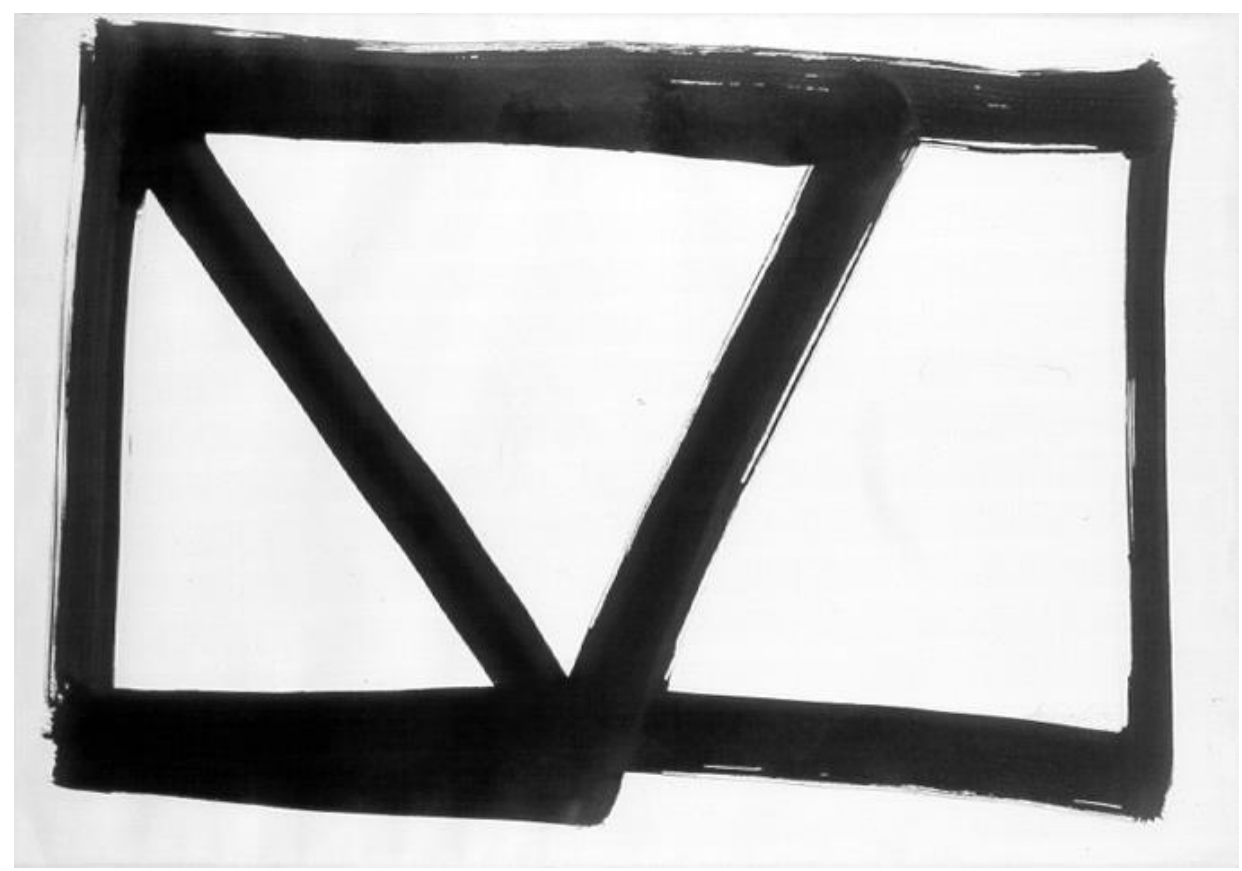

(Sem título, 1976 - Amilcar de Castro) [27]

Em suas esculturas, o vazio emerge à construção de uma geometria sensível que se envolve ao espaço e o reifica, afirmando-o à negatividade produzida por seus cortes e dobras; em seus desenhos, a disponibilidade absoluta do papel surge quase como ao mesmo tempo fundamento e finalidade. Fundamento no sentido de que, diferente da escultura que produz essa virtualidade do vazio e com isso proporciona a experiência topológica do trabalho, no papel, esse vazio só passa a ter algum valor significativo em si a partir de seu traçado com o nanquim. Não há a sobreposição de uma figura sobre o fundo: a condição prévia do papel, em seu branco e aberto campo de disponibilidades, é ressignificada; não é mais uma ultrapassada camada sobre o inscrito e já não mais somente o suporte, é como se o real intuito do desenho fosse afirmar sua gráfica capacidade de construir espaços.

Já em meados da década de 80, Amilcar inicia suas obras de acrílica sobre a tela e a mesma sintaxe construtiva permanece, como em seus outros trabalhos, em um diálogo obstinado entre o que permite o espaço e o que pode propor o material. SE pensarmos em seus desenhos de nanquim sobre o papel, prevalece ainda mais esse aspecto gráfico a que o artista tanto se referia para resumir esses trabalhos, mas em suas acrílicas muitas vezes há a inserção da cor (ainda que ela opere sobre seus princípios construtivistas), traços livres e rápidos, decididos e incisivos como em seus primeiros desenhos, muitas vezes nos dando a impressão 
de que foi feito com apenas uma pincelada. Ou como bem observa a crítica de arte Angélica de Moraes:

Gesto energético: a nova série diverge do traço energético que Amilcar costuma fazer com a trincha, deixando marcas rajadas e uma caligrafia que remete às esculturas angulosas e exatas. é corte e dobra na escultura, linha reta e ângulo na pintura. Agora a pintura traduz outras vertentes das soluções tridimensionais do mestre, aquela que começou a fazer nos anos 80: o corte na espessura do ferro estabelecendo módulos destacáveis. Na tela, o traço se fecha em retângulos e o relevo estabelecido pelo corte se traduz nas linhas oblíquas sugerindo perspectiva. Os blocos de armar feitos de ferro transformaram-se em modulações de retângulos de tinta do plano ${ }^{59}$

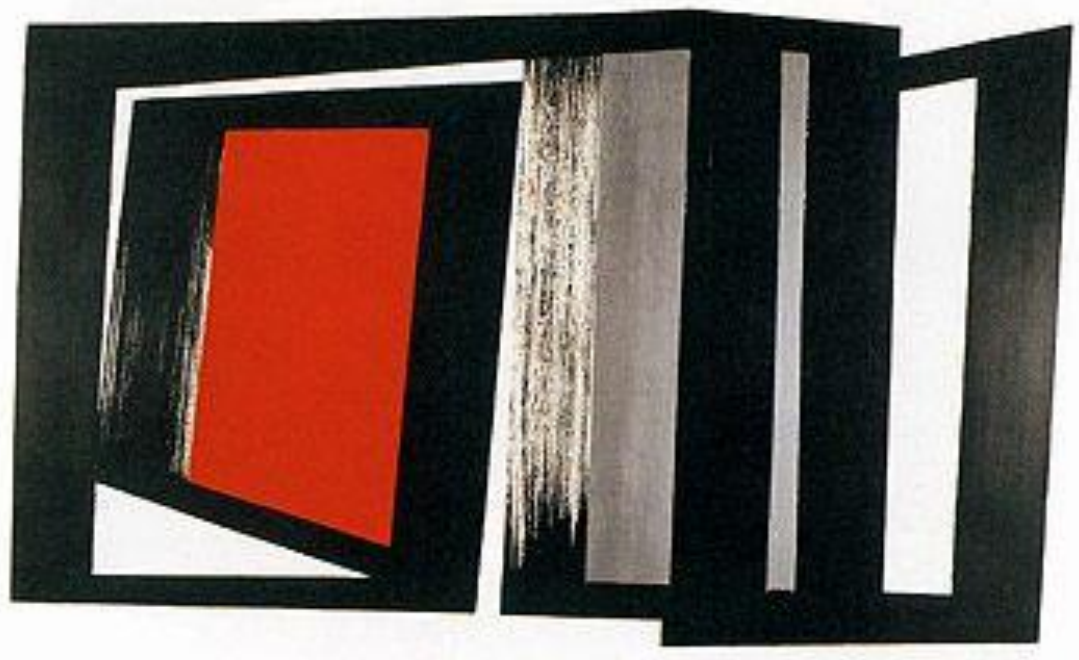

(Sem título, 1989 - Amilcar de Castro) [28]

Nesse sentido, suas obras sobre a tela retomam dois pontos que já erma vislumbrados quando ainda era aluno de Guignard: o gesto fundador e a maneira como seus desenhos se auto envolvem no espaço.

Decidido, incisivo e adâmico, seu gesto sobre a tela retoma a tese de Gullar de que Amilcar ao se lançar a aventura de um único gesto com a trincha sobre a tela é como se o artista estivesse à espera do milagre da forma - não é corrigível, não é

\footnotetext{
${ }^{59}$ MORAES, Angélica de. Gestos livres delimitam espaços exatos/entrevista. O Estado de São Paulo, São Paulo, 14 out. 1995, p. D-4.
} 
retocável, e de certa forma, até o uso da trincha é simbólico nesse sentido, não é a maciez de um pincel, mas a exatidão gestual de um instrumento de superfície achatada e que proporciona uma espessura mais consistente que a do pincel ao mesmo tempo que suas ranhuras quase proporcionam perspectiva e penetração do branco anterior da tela em sua forma inaugurada.

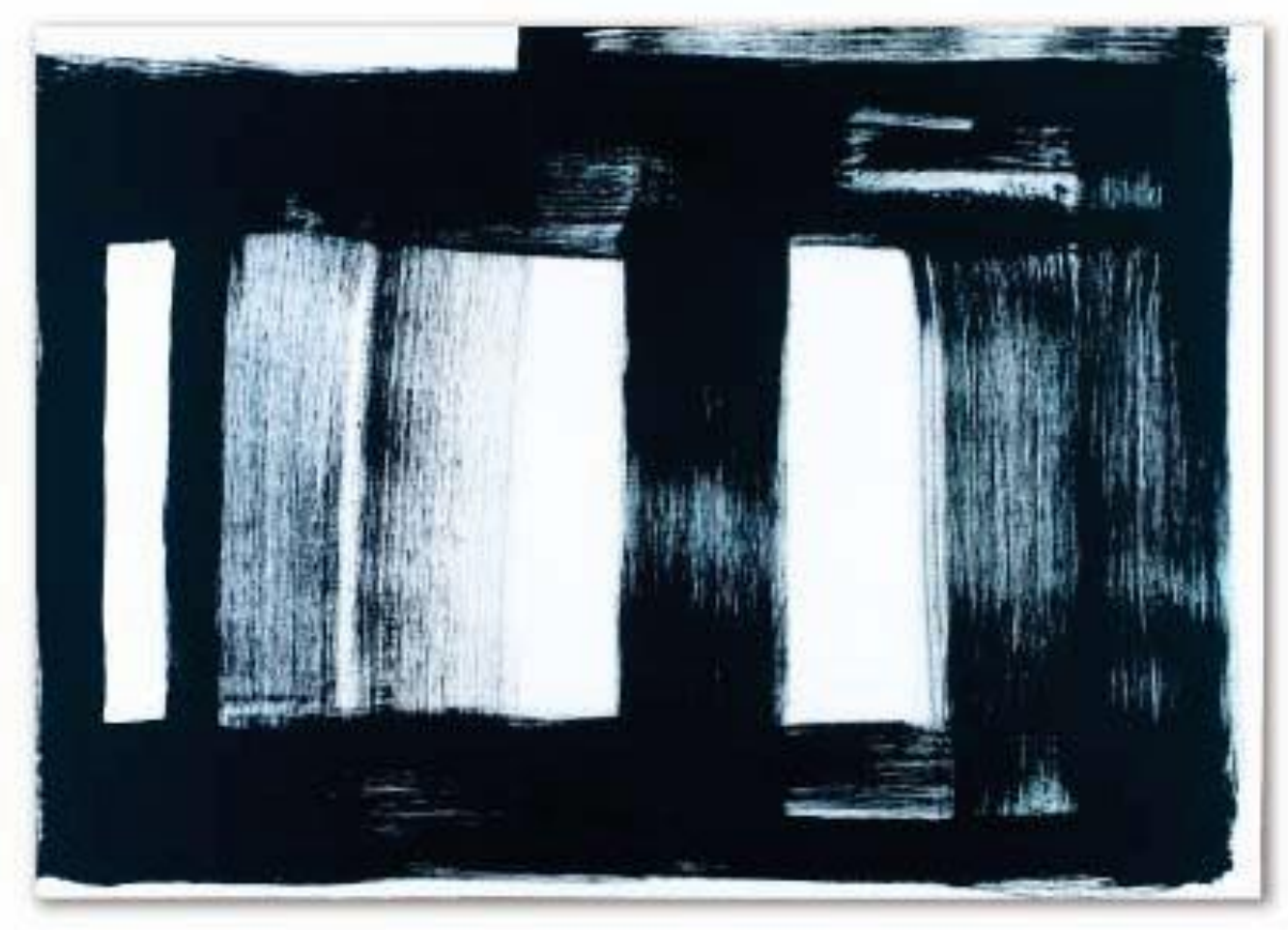

(Sem título, 1998 - Amilcar de Castro) [29]

Essa tela de 1998 é um bom exemplo do que estamos falando em relação ao seu gesto e a maneira como isso se completa ao desenho exatamente por ter sido feito em seus traços livres rápidos. Em algumas partes é evidente que o gesto único da trincha sobre a tela ao ir perdendo a consistência da tinta, o que para outros significaria o momento do retoque, parece dar ao desenho uma penetração da luz, uma vez que pensar o espaço da tela em branco na obra de Amilcar enquanto um fundo é impossível, já que o desenho busca exatamente essa interação. Em outros casos, a consistência torna a faixa de tinta tão obliqua que emula uma perspectivação - nova conquista do espaço.

Já em seus trabalhos sobre a tela em que há a presença da cor, o embate direto e único da trincha sobre a tela dá lugar ao retoque, tendo em vista que esses campos de cor eram pintados com rolos, delimitando bem seu espaço na tela e 
interagindo com os outros campos. O desafio aqui passa a ser o uso da cor sem fugir de sua lógica construtiva. Por isso, o uso da cor surge como uma nova forma de reorganização do espaço, ou seja, retoma o valor do desenho sobre a pintura.

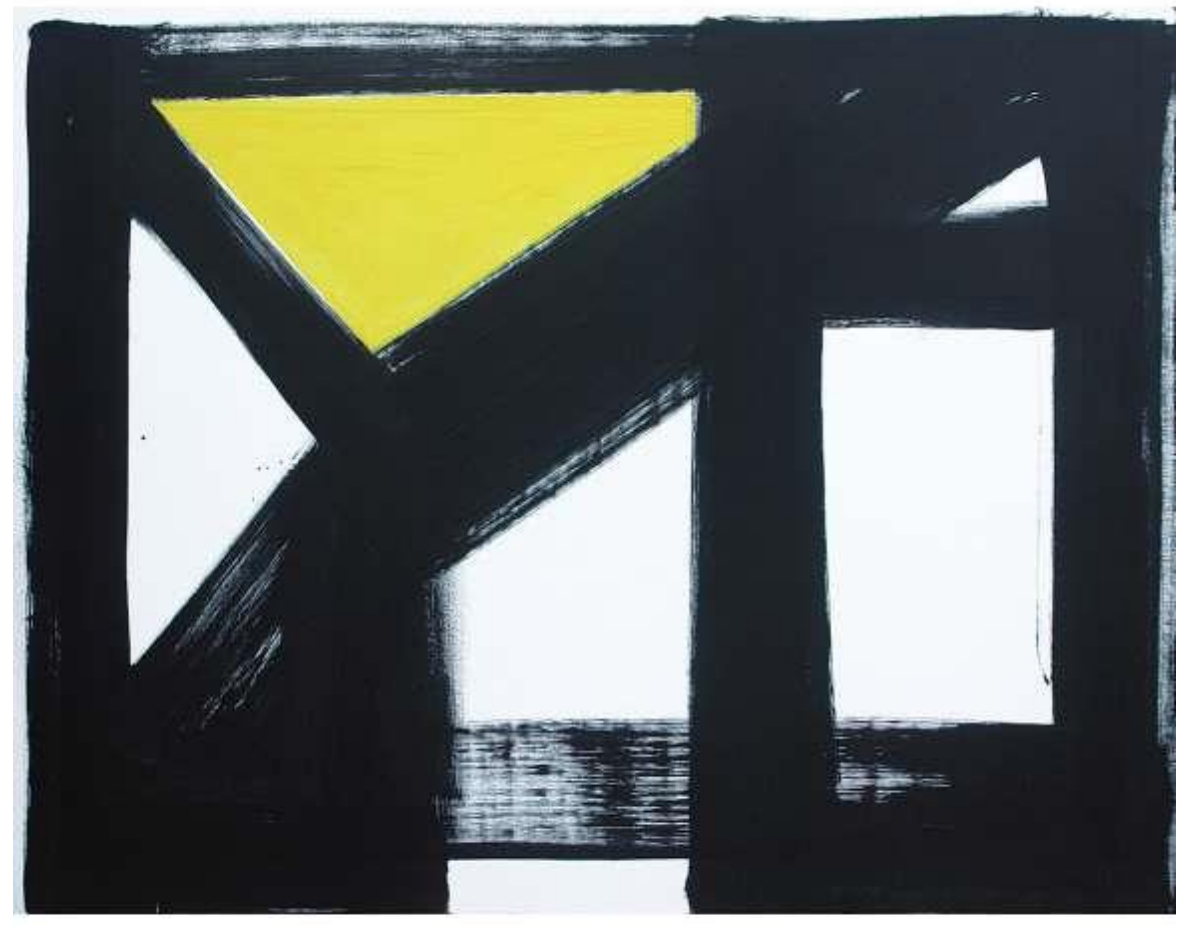

(Sem título, 1994 - Amilcar de Castro) [30]

Tanto nos trabalhos com nanquim quanto em acrílica o que primeiro transparece nos desenhos é o impulso físico do ato de estruturar, a ânsia irreprimível da vontade de ordem que sua geometria impõe enquanto verbo ativo do mundo:

(...) o seu universo geométrico flexibiliza-se, distende-se, graças a uma prática cotidiana isenta dos problemas de viabilidade física inerentes à escultura. A sucessão vertiginosa de imagens do desenho e da gravura revela ao artista tudo o que é possível sem ser, obrigatoriamente, verossímil. E tal fluência rebate sobre a escultura de modo a maleabilizá-la, torná-la mais solta e aérea justo quando busca acentuat sua presença física no mundo. ${ }^{60}$

${ }^{60}$ BRITO, Ronaldo. Amilcar de Castro/ texto Ronaldo Brito; fotos Rômulo Fialdini. Takano Editora. São Paulo, 2001. P. 42. 
Seus desenhos, portanto, aparecem em sua trajetória como a primeira manifestação desse impulso em direção à ordem, já bem visível em seu decidido traço a lápis duro com o mestre Guignard, e mais tarde, perfeitamente incorporado ao seu léxico construtivista, os desenhos passam a funcionar como uma forma de atualização e desdobramento das indagações que o perseguiam desde suas esculturas, não à toa, Amilcar acabava atualizando seu procedimento escultórico após algumas experiências sobre a tela ou o papel, como alguém que compreende e se sustenta nas particularidades de cada material, sem nunca abrir mão de seu projeto: a organização, a construção, a conquista do espaço.

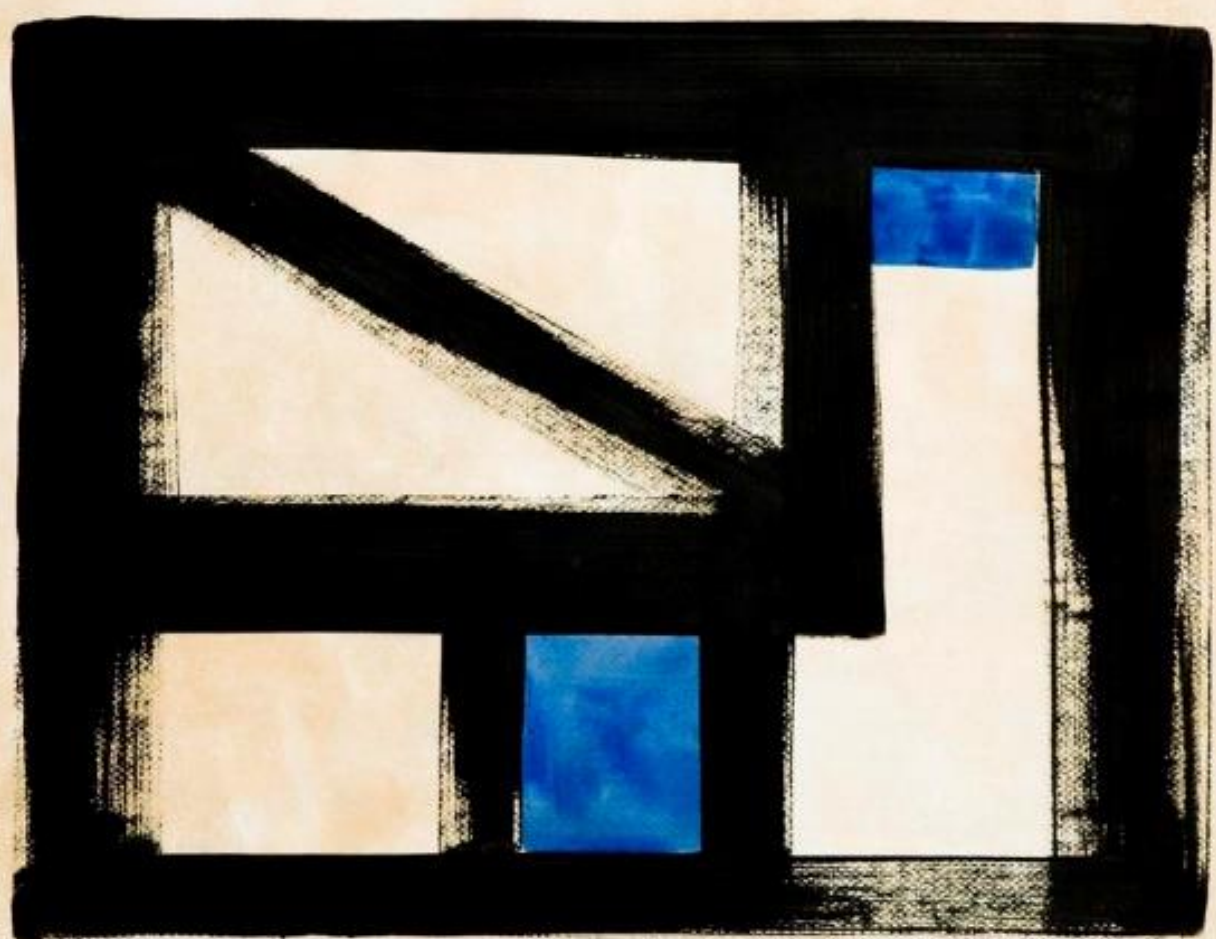

(Sem título, 1988 - Amilcar de Castro) [31] 


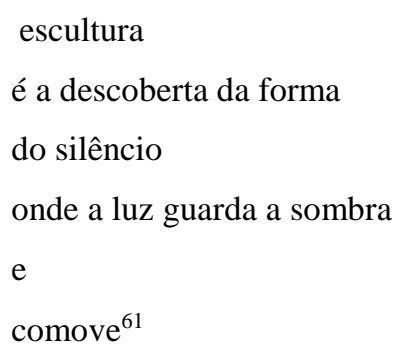

Outra modalidade artística que o acompanharia até o fim da vida é a poesia. Pouco afeito às explicações teorizantes sobre o próprio trabalho, seus poemas acabam por preencher eventuais lacunas sobre seu percurso, uma vez que em muitos Amilcar se debruça sobre o próprio ofício, sobre o decidido ímpeto dos desenhos, sobre a dobra do plano à emersão da tridimensionalidade, de uma geometria que persevera ao mesmo tempo que transcende a si própria.

61 Todos os poemas de Amilcar de Castro citados neste capítulo estão presente em BRITO, Ronaldo. Amilcar de Castro/ texto Ronaldo Brito; fotos Rômulo Fialdini. Takano Editora. São Paulo, 2001. 


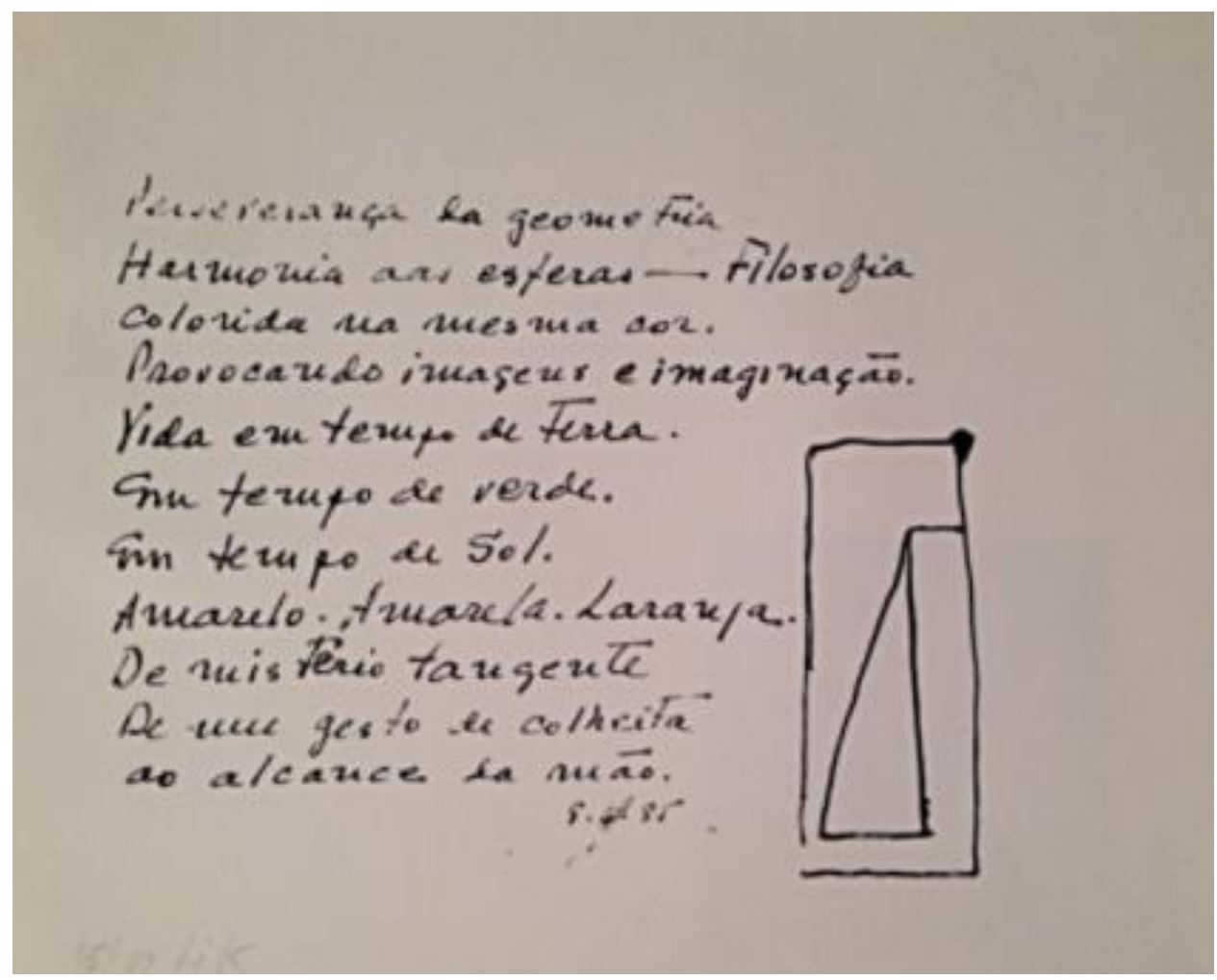

(Poema manuscrito de Amilcar de Castro, 1970)

Não é incomum encontrar em muitos de seus poemas ${ }^{62}$ o desenho, o esboço de uma escultura, quando muitas vezes os próprios poemas referem-se ao trabalho escultórico, deixando evidente que estava para além de um projeto estético somente, as indagações de Amilcar são de uma tal potência existencial que não o escapa e transborda, inclusive formalmente, em seus poemas.

A preocupação de Amilcar com a forma do poema acompanha suas reflexões sobre arte, e uma possível explicação para a frequência desse diálogo é que seus poemas, a princípio, seriam apenas uma forma original de o artista falar de determinados assuntos relacionados com a arte, com função didática, a serem apresentados aos alunos da Escola de Belas Artes, onde lecionaria por alguns anos. Logo esses textos começariam a ganhar publicações esparsas, sobretudo no jornal O Estado de Minas. Com o mesmo rigor, a mesma concisão, esses seus textossínteses, como chama Ronaldo Brito ${ }^{63}$, a um artista tão marcadamente conhecido

\footnotetext{
62 Os poemas de Amilcar de Castro foram colocados em conjunto somente para algumas retrospectivas de sua obra, não tendo publicado nenhum livro de poemas ou organizado antologias. É ainda uma lacuna em sua obra essa coleção dos escritos.

${ }^{63}$ Ver em BRITO, Ronaldo. Amilcar de Castro/ texto Ronaldo Brito; fotos Rômulo Fialdini. Takano Editora. São Paulo, 2001. P. 222
} 
por seu trato com a forma, por sua lógica estrutural, logo o didatismo dos poemas daria lugar a experimentos de síntese e uso gráfico da página de uma maneira pouco usual e de rara consciência formal na poesia brasileira.

\section{A pescaria}

Entre o sentir e a palavra

há um tempo ruminante.

Tempo de silêncio.

Poesia é silêncio encantado

comovido em palavra.

Verruma. Desvela. Estampa.

A linha não existe.

Mas, quando feita pela mão do

homem é desenho.

Obedece como um rio

conspirando com as margens.

é pensamento pensando.

E pensa e risca e divide

e desvela justiça entremeio

entremeando espaços opostos:

mapa de seu destino.

Procuro sempre linguagem

simples

mas, só encontro letras esparsas

- fósseis de mim.

Até parece que o homem,

mesmo perseverando no sensível,

é uma experiência esquecida.

Entretanto, às vezes,

rápido como um peixe na isca

um relâmpago estampa claro a

forma pronta.

De graça à colheita

e à origem do convívio.

E dizem que isso é comum na

pescaria.

(Amilcar de Castro) 
"A pescaria" é um excelente exemplo desse modelo de poema que, se ainda tímido às experimentações que mais tarde o poeta faria, intersecciona seu raciocínio estrutural a sua densidade poética. Nesse poema, Amilcar aponta logo nos primeiros versos para uma ideia do que venha ser poesia que em poemas posteriores ultrapassariam a condição de apenas indagações pra alcançar o espaço físico do poema. Nos versos: "Entre o sentir e a palavra/ há um tempo ruminante. / Tempo de silêncio. / Poesia é silêncio encantado/ comovido em palavra. " Amilcar está discutindo a natureza ontológica do poema, como se o fundamento dessa forma fosse exatamente esse "tempo ruminante" do silêncio: condição prévia do poema (como o vazio é o do mundo em suas esculturas) e comovido pela palavra. Como em suas esculturas, a matéria-palavra é ao mesmo tempo o que configura esse dizer, essa presença física do poema, mas é também a partir da palavra que esse "silêncio encantado" ao qual o poeta se refere pode emergir. Palavra e silêncio assumem uma unidade inseparável, complementar, precípua ao poema enquanto forma.

\author{
É de chapa de ferro \\ de chapa porque pretendo, partindo da superfície \\ mostrar o nascimento da terceira dimensão. \\ De ferro porque é necessário \\ É natural de Minas, está ao alcance da mão \\ Todo mundo sabe trabalhar em ferro \\ A superfície é domada - é partida e vai sendo dobrada - \\ É quando, e por fatalidade, o espaço se integra criando o não previsto. \\ É pura surpresa. \\ É como um gesto inesperado. \\ Um gesto espontâneo. \\ Espontâneo como se fosse o primeiro \\ - aquele que fundamenta a comunhão com o futuro. \\ A escultura que faço é uma pesquisa da origem da própria escultura
}

por isso é simples

descobre a força do que é original.

Sol de muito tempo

entre noites dormindo

acorda e ilumina e ascende 


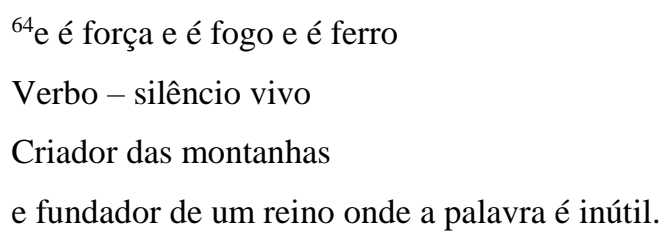

(Sem título, Amilcar de Castro)

Afora o didatismo já evidente em outros poemas, este poema reafirma e justifica as principais escolhas feitas pelo escultor - o ferro, o corte, a dobra, a tridimensionalidade e a relação com o plano -, ao mesmo tempo que traz algumas novidades: no terceiro verso do poema há um deslocamento do início da frase, não obedecendo à norma de justificação da esquerda para a direita da página; e ao iniciar a frase ao meio da página em relação ao verso anterior, abrindo um espaço em branco no início do verso e, levemente, abrindo uma brecha de silêncio no poema. De maneira sutil, Amilcar desdobra sua própria ideia de um "silêncio encantado", do Verbo enquanto um "silêncio vivo", para a forma do poema. Como em suas esculturas, o espaço é ativado, mobilizado e sensível.

Desenho
é
o espaço
na medida
do
sonho

(Amilcar de Castro)

Amilcar experimenta a possibilidade de, para além das palavras e com elas, construir a partir do espaço do poema. Muitas vezes versos simples, livres, sintéticos que se desdobram, ampliam o silêncio da página, deslocam-se por sua superfície, outrora tão normatizada que tal possibilidade surge quase como uma inauguração do papel, de seu espaço, agora reificado pelo poema.

Nesse sentido, cabe pensar até na produção de uma negatividade positiva em seus poemas, o que em suas esculturas pode ser lido como a experiência 
topológica de envolvimento entre o vazio $e$ o cheio, a conquista da tridimensionalidade a partir de um plano a que se remete enquanto origem, mas não se traduz em presença física, em representação. São assim também seus poemas: a palavra comove, encanta esse silêncio que o poema quer dizer e diz no deslocamento de suas palavras, na fragmentação de sua frase e forma, a ativação de um espaço novo na página que, como suas esculturas, dialoga o dito e o não-dito, esse silêncio comovido cujo dizer é a própria elucidação de sua negatividade positiva - seu dizer mudo e vivo.

Em experiências formais ainda mais audaciosas, Amilcar constrói um poema cuja unidade é móvel e articulada. O poema pode ser lido somente pela direita, ou pelo poema que também se desenrola à esquerda da página ou essas unidades podem ser articuladas e formar uma nova unidade de sentido, um terceiro poema. Como não pensar em seus sólidos geométricos com seus deslocamentos e peças articuladas?

\begin{tabular}{|c|c|}
\hline Sentir & Pouco \\
\hline pensar & importa \\
\hline pintar & o \\
\hline desvendar & dia \\
\hline devaneio & $\mathrm{a}$ \\
\hline devoto & noite \\
\hline tanto & o \\
\hline quanto & ontem \\
\hline \multirow[t]{2}{*}{ só } & ou \\
\hline & o \\
\hline ver & hoje \\
\hline \multicolumn{2}{|l|}{$\mathrm{a}$} \\
\hline cor & a natureza sabe antes \\
\hline $\mathrm{a}$ & que \\
\hline forma & o \\
\hline o & tempo não tem emenda \\
\hline \multicolumn{2}{|l|}{ mundo } \\
\hline & desde longe \\
\hline descobrir o silêncio forte & de muito longe \\
\hline \multirow[t]{2}{*}{ o pensamento simples } & envolto em neblina densa \\
\hline & além de toda a sabedoria \\
\hline atesta & pressente-se \\
\hline
\end{tabular}


$\mathrm{e}$

contesta

O

tempo

e

comove

(Amilcar de Castro) de graça a vida

é uma canção que se ouve

e vai

contando história antiga

e mesmo de olhos fechados

vê

na luz subterrânea

em velocidade instantânea

a comunhão sem tempo revelada

que estampa e cala

mas em silêncio fala:

- arte é vida

O poema só é possível em seu movimento, na compreensão espacial de suas pausas, na articulação rítmica de seus blocos. Um poema de rara concisão e polissemia em que ao "descobrir o silêncio forte/ o pensamento simples/ atesta/ e/ contesta/ o/ tempo/ e/ comove."

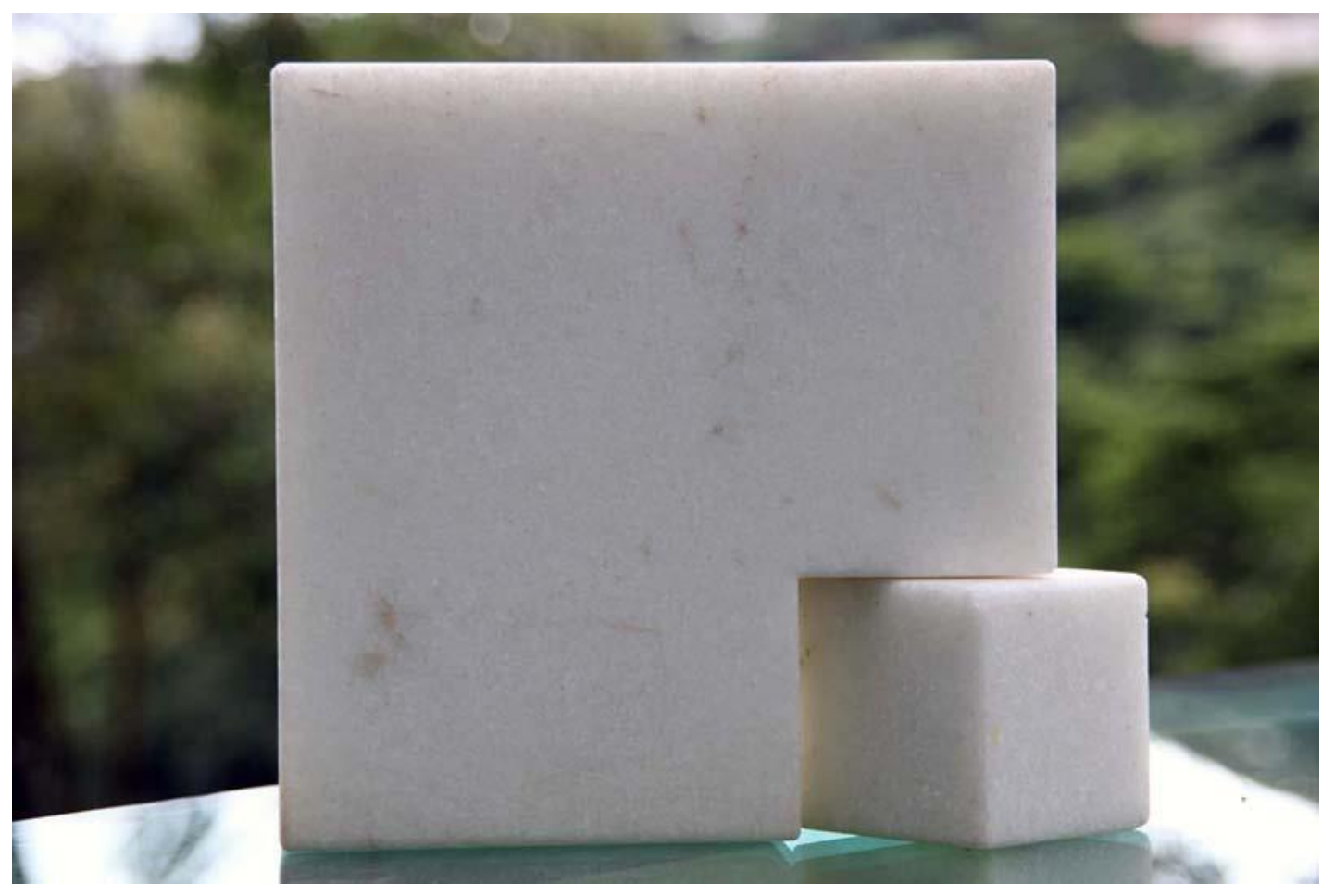


(Sem título, 2001 - Amilcar de Castro) [32]

Os poemas quando não atualizam teoricamente o que suas esculturas realizam materialmente, são também indagações, novos questionamentos e, consequentemente, um novo suporte ou campo de experimentação espacial para o artista. Por isso ser interessante acompanhar o trajeto de seus poemas, ainda que o próprio nunca os tenha colocado em alguma seleção ou escala cronológica, estão relacionados. De desdobramentos literários de suas esculturas eles começam a conquistar seu próprio espaço na obra de Amilcar, passa o poema a também ser esse "pensamento pensando" que o escultor agora se lança as palavras. As palavras que estão para o silêncio como "a árvore desenha o céu"65.

\author{
Sei que não quero contar \\ a história dos espaços já construídos. \\ Por mais ontens que se guarde \\ mesmo por amor ou saudade \\ não faremos amanhecer jamais. \\ Gostaria, sim, de mostrar o espaço \\ ainda não visto \\ o espaço reinventado de assombros \\ e sem alarde \\ mas, que se mostra novo, sempre novo.
}

Nada é mais vulgar que o espaço

nem nada mais vivo quanto a luz

Quando a descoberta se faz sentir

é no presente que antecipo o futuro

mesmo no tempo que se armam as forças

para desvendar a forma clara.

Creio

Tenho fé na forma que não deixa resto

Que estampa e cala

\footnotetext{
${ }^{65}$ Verso de um poema de Amilcar que pode ser encontrado, assim como boa parte de seus poemas, em BRITO, Ronaldo. Amilcar de Castro/ texto Ronaldo Brito; fotos Rômulo Fialdini. Takano Editora. São Paulo, 2001. P. 137.
} 
Como a fala do poeta

Que em silêncio contém o mundo.

(Amilcar de Castro)

Seu impulso estrutural é seu impulso lírico, sua potência existencial, que se em suas esculturas acompanhava o mesmo impulso da matéria, ávida a conquista do espaço, de seu aparecimento enquanto forma, de sua eterna atualização; em seus poemas, em que silêncio e palavra operam na mesma intensidade, emerge formalmente esse desvelamento, essa remissão ao não-dito como parte constitutiva do poema.

Corte e Dobra

Toda superfície cria mistério.

O muro divide, proíbe, estanca, não passa,

ou bloqueia: é tumba, é campa,

é tampa - não desce e não sobe.

Esse não permanente

aguça e lança:

e além? e embaixo?

e em cima? e dentro? e fora?

Cria o prazer de romper, atravessar,

conquistar o outro lado,

o ar, o ver

e amanhecer no mesmo horizonte.

Quando corto e dobro

uma chapa de ferro ou somente

corto

pretendo

abrir um

espaço 
matéria bruta

é luz que vela e revela

a comunhão do

opaco

com o espaço dos

astros

espaço

que descobre o

renascer

redimindo a matéria pesada

na intenção

de voar.

(Amilcar de Castro)

Lidos em voz alta, por exemplo, seus poemas ainda não acontecem. Amilcar ativa o espaço do poema, convoca a uma leitura atenta aos aspectos estruturais, ao aparecer da forma, a esses seus silêncios, virtualmente construídos à intenção de repor seu valor fenomenológico. Seu ritmo é a pausa. Suas palavras são convocadas a construir um novo espaço sobre o papel, totalizando a potência do poema oral e, sobretudo, visualmente. Quer nos propor um reconhecimento gráfico do silêncio, como se "abrir um espaço ao amanhecer na matéria bruta" ampliasse o dizer exímio gesto poético. 


\section{Considerações finais}

Tudo na obra de Amilcar de Castro recusa as formas fáceis e impositivas. O artista está atento e disposto aos imperativos de seu tempo apenas se atenderem as suas demandas particulares. Suas escolhas o conjuga e o distancia ao mesmo tempo de seus companheiros de cena. Ao que se espera de adaptação, Amilcar atualiza a partir do mesmo. Quer a aventura da coerência e a ação sobre o espaço.

Ainda aluno de Guignard, Amilcar aprende a confiar em seu gesto incisivo, desenhando a lápis duro, como insistia o mestre, que, por produzir sulcos no papel, exigia decisão no traço. Não havia conserto para os erros. O gesto era único, estruturante, demarcatório. Uma relação com o espaço (na ocasião, ainda da tela) emulada pelas paisagens imaginantes de Guignard: a aversão do pintor aos limites se transforma, na futura obra de Amilcar, na alegria de multiplicar as relações e os espaços.

Uma força estrutural expressa na geometrização do mundo. Início dos anos 50 no Brasil, entrada do pensamento construtivo na arte brasileira e adesão de Amilcar à escultura como principal forma de expressão e desse seu ímpeto. A assinatura do Manifesto Neoconcreto como a aproximação entre sua linguagem construtiva aos princípios da vanguarda. A tomada de posição em relação aos concretistas como uma clara e irrevogável afirmação da potência poética e das particularidades sensíveis de sua escultura, que nunca se rendeu ao racionalismo ortodoxo dos concretos e nem a uma ética da intersubjetividade proposta por seus companheiros.

Amilcar trabalha no cerne do fazer poético. Constrói esculturas a partir de seu raciocínio planar mas não nos repõe sua origem. Produzindo uma negatividade positiva, como já discutimos neste trabalho, suas esculturas remetem a um plano originário que nunca se realiza virtualmente, mas é possível reconhecê-lo em sua ausência. Experiências topológicas que fogem ao didatismo processual, muitas vezes presente em algumas obras construtivistas, e que alcança uma dimensão existencial rara.

Uma obra de predomínio expressivo da matéria, em que o aparecimento da forma (tão caro aos preceitos construtivistas), a partir de intervenções rigorosas, 
recusa o recalque da matéria que lhe dá realidade. A corrosão da ferrugem como ação do tempo sobre a obra - como um dado e parte integrante. Uma obra que se atualiza a cada visada, mas traz consigo as marcas de sua passagem. A oposição do ferro às torções; a resistência material somada à reflexividade proporcionada pela dobra, que dá certa interioridade ao trabalho e nos coloca diante de um impasse: a ânsia e a incapacidade de reconstituir perceptivamente a origem de suas esculturas.

$\mathrm{O}$ procedimento de corte enquanto uma fissura à unidade da matéria $\mathrm{e}$ delimitação de um novo espaço conquistado a partir desse vão. $\mathrm{O}$ corte enquanto desenho e um modo de articular o espaço que também o diferencia de outros importantes artistas neoconcretos como resume o crítico Rodrigo Naves:

\begin{abstract}
A procura de um desdobramento formal que superasse o contraste entre figura e fundo levou Hélio Oiticica e Lygia Clark a trazer seus trabalhos para o espaço, colocando-os numa situação de maior liberdade em relação aos limites impostos pelo plano pictórico. No caso de Lygia Clark, o percurso que leva das Superfícies moduladas ao Túnel - passando pelos Bichos, Trepantes, Obras moles, A casa é o corpo, Baba antropofágica, entre outros - descreve um movimento quase paradoxal: a trajetória que conduz do plano ao volume gera formas cujo sentido é de uma interioridade crescente. A conquista do espaço, em última análise, não corresponde a uma exteriorização das formas, e sim um ensimesmamento problemático (... $)^{66}$
\end{abstract}

Uma das premissas defendidas pela Teoria do não-objeto proposta por Ferreira Gullar no auge da produção neoconcretista é a de que a passagem do plano para a tridimensionalidade seria um caminho já insinuado na História da Arte e fruto dessa exigência construtiva da nova vanguarda. Essa passagem obrigatória seria evidência da posição, duramente conquistada pelo não-objeto, de ponto culminante de uma história dialética do modernismo. Como também já discutimos nesse trabalho, Gullar legitima sua própria vanguarda, atribui a ela uma historicidade e uma coerência que a obra de Amilcar, por todas essas específicas e rigorosas escolhas já mencionadas, coloca-se como um ponto cego.

Referência na arte tridimensional brasileira, Amilcar estabelece essa transição, essa "passagem obrigatória" do plano para a terceira dimensão, a partir de experimentações no espaço, a partir de uma escultura que ao mesmo gesto (corte) divide o peso da matéria a equilibrando e proporciona que o trabalho possa se

\footnotetext{
${ }^{66}$ NAVES, Rodrigo. A forma difícil: ensaios sobre arte brasileira. Editora Atica. São Paulo, 1996. P.243
} 
autoenvolver no espaço. As esculturas, sobretudo as de corte e dobra, surgem de intervenções que as colocam de saída como mediação. De algum modo, a tensão produzida nas dobras perpassa as partes vazadas e empresta corpo ao que era apenas vão. Somente assim podemos verdadeiramente atravessar aquele vazio e experimentar regiões situadas fora do âmbito de nossa intimidade. Por mais simples que possa parecer seu procedimento, a operação em curso é de uma profundidade existencial e fenomenológica que ao mesmo tempo que o insere na História da Arte como um escultor pertencente à vanguarda neoconcretista, também o afasta de seus pares à medida que suas escolhas se tornam cada vez mais justificadas em um léxico singular e coeso. Amilcar amplia a discussão proposta por sua vanguarda ao passo que se mantém cada vez mais fiel a si e surdo às imposições.

Por isso o objetivo deste trabalho ser o de compreender sua obra não só enquanto o fruto de influências e circunstâncias propícias ao surgimento desse trabalho, mas exatamente o ponto de inflexão entre Amilcar e sua geração a partir de sua inabalável coerência formal. Amilcar mantém-se ávido a investigar e ampliar as próprias premissas em diferentes suportes, e o que percebemos é um trabalho que, seja em suas esculturas, em seus desenhos sobre a tela, ou até mesmo seus poemas, prevalece a força expressiva da matéria e obstinação pela conquista do espaço.

Amilcar reifica o espaço em seu ato de espacializar. Repõe o peso existencial e o acontecimento (fenomenológico) de seus trabalhos a uma impessoalidade comovente. Com seu gesto decidido e irretocável suas esculturas inauguram um novo espaço, aberto, não-projetivo, que disposto ao tempo, como nós, resiste e afirma-se não em um eu expressivo, mas factível, assumindo essa subjetividade anônima fundamental para sua universalidade. Até mesmo a monumentalidade que existe em suas esculturas deriva dessa dimensão impessoal. Avesso aos intimismos, os trabalhos demonstram certo orgulho em sua solidão altiva. Afinal, eles traçam, ao menos idealmente, o território de uma convivência complexa e respeitosa, na qual a indiferenciação provocada por relações entre indivíduos e grupos sociais carentes de identidade e estrutura é posta em xeque. 
Passagens que - apesar de serem passagens - traçam limites entre regiões tão distintas e configuradas descartam a sedução da indiferenciação ${ }^{67}$.

Uma monumentalidade afastada de qualquer dimensão simbólica e que ainda nos diz em sua impessoal e poética voz. Um artista que com mestria fez desenhos, esculturas e poemas; com uma capacidade única de passar de um meio a outro sem perder a tensão que move sua obra e o princípio que o norteia - seu modo generoso de conquistar a forma e o espaço. Como se esse estranhamento de matéria e forma aludisse a uma dimensão crítica de nossos tempos: Amilcar reluta em reduzir o mundo a simples imagens, como muitas vezes até a arte parece colaborar. Produto de uma experiência que abrange toda complexidade desse envolvimento com o espaço e sua conquista, a resistência, a temporalidade e a origem, sua obra é um acontecimento, inaugura-se nessa facticidade, nesse confronto com nossa própria incompletude, nosso nexo de permanência e altiva solidão. Um trajeto infenso à narrativa representacional que ainda assim, nos fazendo ver o que está além daquilo que poderíamos acreditar uma simples extensão de nossos gestos, acaba por se afirmar como um testemunho poético e definitivo de nossa mesma resistência no mundo.

${ }^{67}$ NAVES, Rodrigo. A forma difícil: ensaios sobre arte brasileira. Editora Atica. São Paulo, 1996. 


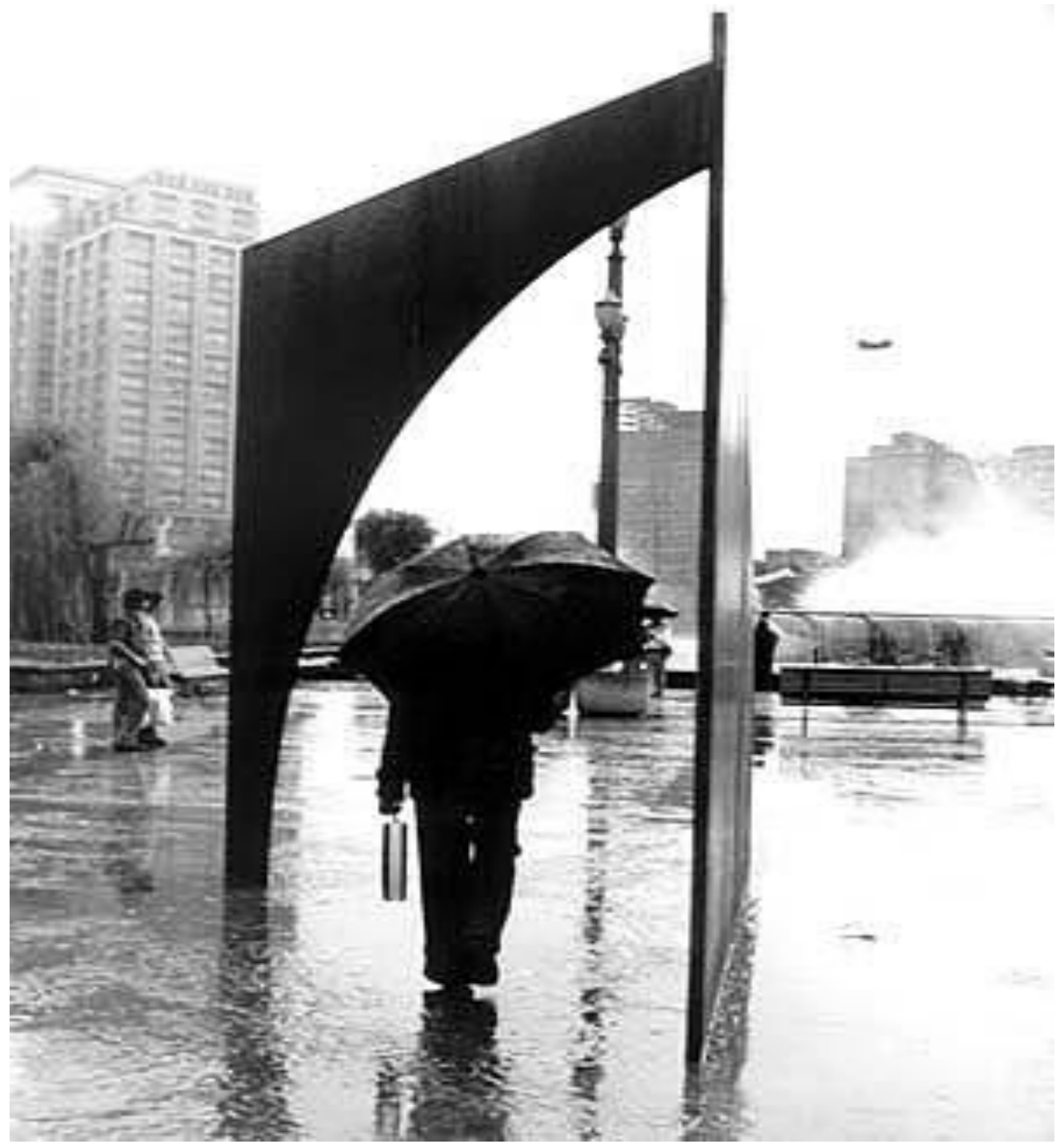

(Sem título, 1979 - Amilcar de Castro) 


\section{Referências bibliográficas}

ABBAGNANO, Nicola. Dicionário de filosofia. 2. éd. São Paulo: Mestre Jou, 1982.

ALVES, José Francisco. Amilcar de Castro: Uma retrospectiva. Pref. Paulo Sérgio Duarte. Porto Alegre, Fundação Bienal de Artes Visuais do Mercosul, 2005.

AMARAL, Aracy. Amilcar de Castro - Desenhos. Gabinete de Artes Gráficas, São Paulo, 4/1978.

AMARAL, Aracy. $O$ vigor da expressividade fundada na geometria. In: Amilcar de Castro. Individual na Galeria de Arte Paulo Vasconcellos, São Paulo, 5/1988.

AMARAL, Araci Abreu (org.) Projeto construtivo brasileiro na arte (1950 - 1962). São Paulo: Pinacoteca do Estado, 1977.

BELLUZZO, Ana Maria. Ruptura e Arte Concreta. In: AMARAL, Aracy (coord.). Arte construtiva no Brasil: Coleção Adolpho Leirner. São Paulo: DBA, 1998.

BENSE, Max. Pequena estética (org. Haroldo de Campos; trad. J. Guinsburg e Ingrid Dormien Koudela). São Paulo: Perspectiva, 2009.

BRITO, Ronaldo. Experiência crítica (org. Sueli de Lima). São Paulo: Cosac Naify, 2005.

BRITO, Ronaldo. Amilcar de Castro; fotos Rômulo Fialdini. São Paulo: Takano Editora, 2001.

BRITO, Ronaldo. Neoconcretismo: vértice e ruptura do projeto construtivo brasileiro. São Paulo: Cosac Naify, 1999.

CHIARELLI, Tadeu. Amilcar de Castro: corte e dobra. São Paulo: Cosac \& Naify, 2003.

CLARK, Lygia. 1960: Os Bichos - Texto de Lygia Clark no catálogo LYGIA CLARK.

DUARTE, Paulo Sérgio. Amilcar Desenha. Panorama da Arte Atual Brasileira 1999. Museu de Arte Moderna de São Paulo, 1999. 
DUARTE, Paulo Sérgio. Amilcar de Castro - A Aventura da Coerência. In: Duarte, Luisa. Paulo Sérgio Duarte - A trilha da trama e outros textos sobre arte. Rio de Janeiro: Funarte, 2004.

DUARTE, Paulo Sérgio. Anos 60: Transformações da Arte no Brasil. Rio de Janeiro: Editora Campos Gerais, 1998.

FERREIRA, Glória. Amilcar de Castro. Kalil e Lauar Galeria de Arte, Belo Horizonte, 4/2000.

FREITAS, Iole de. A precisão do risco. Jornal de Resenhas/Folha de São Paulo, São Paulo, 11 jul. 1998, p.10.

GULLAR, Ferreira. Manifesto Neoconcreto (1959). In: AMARAL, Araci Abreu (org.) Projeto construtivo brasileiro na arte (1950 - 1962). São Paulo: Pinacoteca do Estado, 1977.

GULLAR, Ferreira. O quadro e o objeto. In: GULLAR, Ferreira. Argumentação contra a morte da arte. 3 ed. Rio de Janeiro: Editora Revan, 1993.

GULLAR, Ferreira. Arte Neoconcreta: uma experiência radical. In 1. Neoconcretismo/1959-1961. Ciclo de Exposições sobre Arte no Rio de Janeiro. Galeria de Arte BANERJ, 9/1984.

GULLAR, Ferreira. Espaço abre espaço. Isto È, 4 dez. 1985.

GULLAR, Ferreira. Etapas da Arte Contemporânea: do cubismo ao neoconcretismo. Editora Nobel. São Paulo, 1985.

GULLAR, Ferreira. Em alguma parte alguma. Editora José Olympio. Rio de Janeiro, 2010.

GULLAR, F. Teoria do não-objeto (1960). In AMARAL, A. (Org) Projeto construtivo brasileiro na arte (1950-1962). São Paulo: Pinacoteca do Estado, 1977.

HUSSERL, Edmund. A Ideia da Fenomenologia. Trad. Artur Morão. Lisboa, Port.: Edições 70, 2014.

MARTINS, Sergio Bruno. Entre a fenomenologia e o historicismo: Amílcar de Castro enquanto ponto-cego da teoria do não-objeto. Disponível em https://www.academia.edu/24061256/Entre_a_fenomenologia_e_o_historicismo_ Amilcar_de_Castro_enquanto_ponto_cego_da_teoria_do_n\%C3\%A3o-objeto 
MARZANO, Angelo. Amilcar de Castro - desenhos e esculturas. Galeria de Arte da Universidade Federal Fluminense, 4/1993.

MORAES, Angélica de. Gestos livres delimitam espaços exatos/entrevista. O Estado de São Paulo, São Paulo, 14 out. 1995.

MORAIS, Frederico. O primeiro gesto. In: Brito, Ronaldo et al, São Paulo: Takano, 2001. P. 167.

MOURA, Antonio de Paiva. Memória histórica da Escola Guignard. Belo Horizonte: Sindicato dos Escritores, 1993.

NAVES, Rodrigo; MESQUITA, Tiago. Amilcar de Castro, Mira Schendel, Sergio Camargo, Willys de Castro/ Rodrigo Naves e Tiago Mesquita. São Paulo: Instituto de Arte Contemporânea - IAC, 2006.

NAVES, Rodrigo. A forma difícil: ensaios sobre arte brasileira. Editora Atica, São Paulo. 1996.

OITICICA, Hélio. Amilcar de Castro. In: Naves, Rodrigo, et al (p. 152 a 155) [Habitat, n 83, 1965].

PAZ, Octavio. O arco e a lira (trad. Ari Roitman e Paulina Wacht). São Paulo: Cosac Naify, 2012.

PEDROSA, Mário. Mário Pedrosa - Arte: Ensaios críticos. São Paulo: Cosac Naify, 2015.

PEDROSA, Mário. Forma e percepção estética. São Paulo: EDUSP, 1997.

PEDROSA, Mário. Encontros (org. César Oiticica Filho). Rio de Janeiro: Azougue, 2013.

ROSA, João Guimarães. Grande Sertão: veredas. Editora Nova Fronteira. Rio de Janeiro, 2006. 


\section{Anexo}

Anexo I - Obras citadas

[1] CASTRO, Amilcar de. Vista de Ouro Preto. 1949. Lápis de cera sob papel, 38 cm x 55 cm. Coleção Antonio Carlos de Castro.

[2] GUIGNARD, Alberto da Veiga. Noite de São João. 1942. óleo sobre tela, 41 cm x 33 cm. Fundação Cultural de Curitiba.

[3] CASTRO, Amilcar de. Sem título, 1990, Gravura em metal, 50 X 70 CM, Edição de 20

[4] CASTRO, Amilcar de. Sem título, 1999, Acrílica sobre tela, 100 X $200 \mathrm{~cm}$

[5] GUIGNARD, Alberto da Veiga. Ouro Preto, 1946, Aquarela e Nanquim.

[6] BILL, Max. Unidade Tripartida, 1949. Aço inoxidável, 114 x 88,3 x 98,2 cm. Museu de Arte Moderna de São Paulo.

[7] CASTRO, Amilcar de. Sem título, 1998. Aço, 220 x 5 cm. Coleção Marcos Carneiro

[8] CASTRO, Amilcar de. Sem título, 1979. Aço, 300 x 350 x 5 cm. Praça da Sé São Paulo/SP

[9] CLARK, Lygia. Bichos, 1960. Alumínio, 60 cm.

[10] CASTRO, Amilcar de. Sem título, 1970. Aço, 90 x 175 x 41 x 3,2 cm. Coleção Tomie Ohtake.

[11] CASTRO, Amilcar de. Sem título, 1970. Aço, 23 x 22 x 4 cm.

[12] WEISSMANN, Franz. Fita, 1985. Aço Pintado, 240 x 240 cm.

[13] WEISSMANN, Franz. Diálogo, 1979. Aço pintado, 4,43 x 5,15 x 1,5 m. Praça da Sé - São Paulo/SP. 
[14] CASTRO, Amilcar de. Sem título, 1980. Aço, 350 x 5 cm. Coleção Manuel Macedo.

[15] CASTRO, Amilcar de. Sem título, 1952/2000. Aço, 180 x 180 x 180 x 0,6 cm. Coleção Antonio Quintella.

[16] CASTRO, Amilcar de. Sem título, 1956. Aço, 100 x 130 x 135 cm. Museu de Arte Moderna do Rio de Janeiro.

[17] CASTRO, Amilcar de. Sem título, 1959. Aço, 52 x 35 x 30 cm. Coleção Nadir Farah.

[18] CASTRO, Amilcar de. Sem título, 1959. Aço, 140 x 149 cm.

[19] CASTRO, Amilcar de. Sem título, 1959. Aço, 52 x 35 x 30 cm.

[20] CASTRO, Amilcar de. Sem título, 1980. Aço, 28 x 38 x 5 cm. Coleção Marilia Razuk.

[21] CASTRO, Amilcar de. Sem título, 1970. Aço inoxidável, 52 x 18 x $26 \mathrm{~cm}$ (montagem variável). Coleção Susana e Ricardo Steinbruch

[22] CASTRO, Amilcar de. Sem título, 1980. Aço, 150 x 150 x 30 cm. Coleção do artista.

[23] ALBERS, Joseph. Sem título, 1928. Papel.

[24] SACILLOTTO, Luiz. Concreção 5942, 1959. Alumínio pintado, 31,1 x 16,8 x 31,4 cm. Coleção Adolpho Leirner.

[25] CASTRO, Amilcar de. Sem título, 1966. Aço, 50 x 49,5 x 16 cm.

[26] CASTRO, Amilcar de. Sem título, 1977. Acrílica sobre tela. 100 x $70 \mathrm{~cm}$. Coleção Allen Roscoe.

[27] CASTRO, Amilcar de. Sem título, 1976. Acrílica sobre tela. 130 x 100 cm.

[28] CASTRO, Amilcar de. Sem título, 1989. Acrílica s/ tela, 210 x $160 \mathrm{~cm}$.

[29] CASTRO, Amilcar de. Sem título, 1998. Acrílica s/ tela, 130 x $100 \mathrm{~cm}$. 
[30] CASTRO, Amilcar de. Sem título, 1994. Acrílica s/ tela, 210 x $160 \mathrm{~cm}$.

[31] CASTRO, Amilcar de. Sem título, 1988. Acrílica s/ tela, 80 x $80 \mathrm{~cm}$.

[32] CASTRO, Amilcar de. Sem título, 2001. Mármore, 210 x 210 x $70 \mathrm{~cm}$. Prefeitura Municipal de Brusque. 